Historic, Archive Document

Do not assume content reflects current scientific knowledge, policies, or practices. 



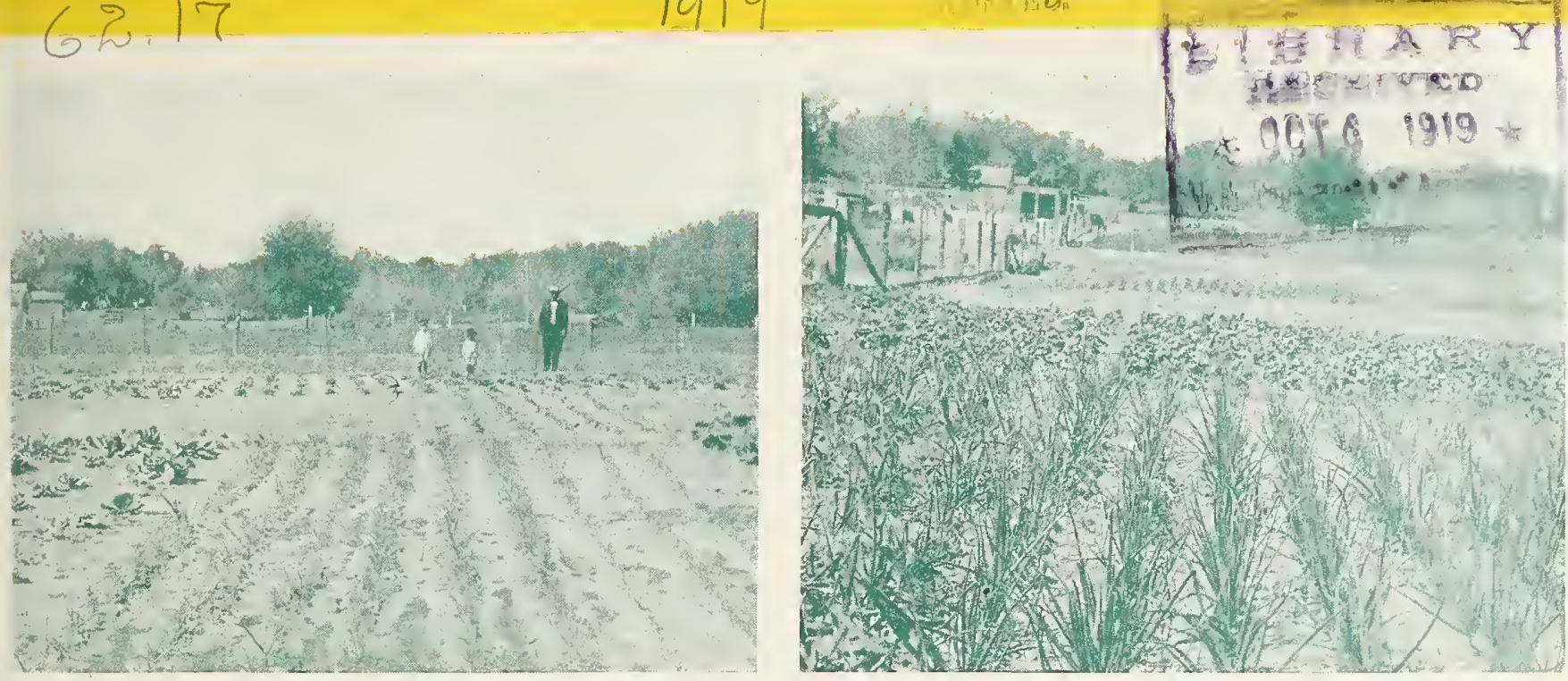

Two photos taken recently on Mr. E. A. Martin's "Roseland Farm," where Ey-Test seeds are tried out and given a Real Test before being sold to our customers
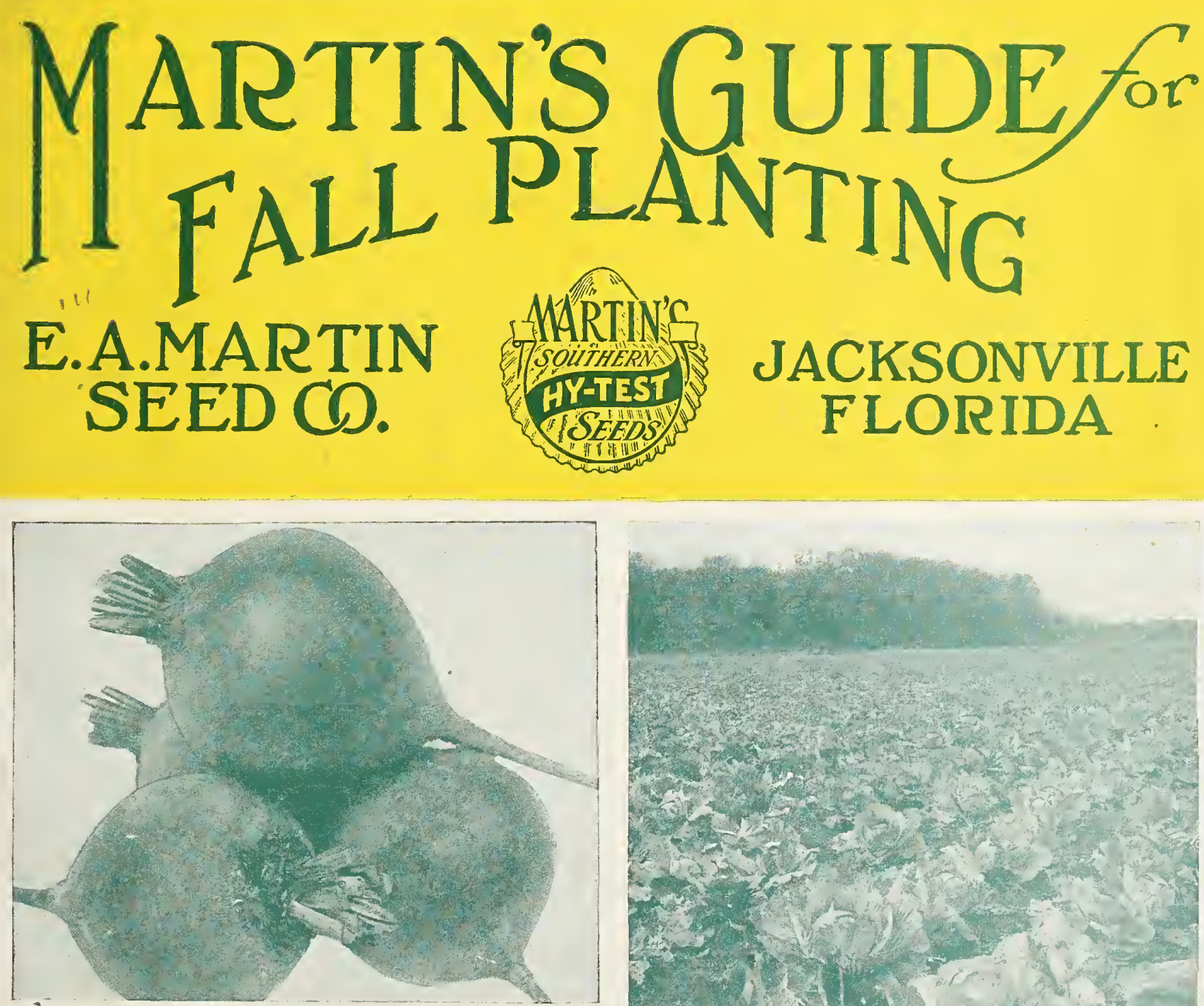

Above-Martin's Dark Red Brets

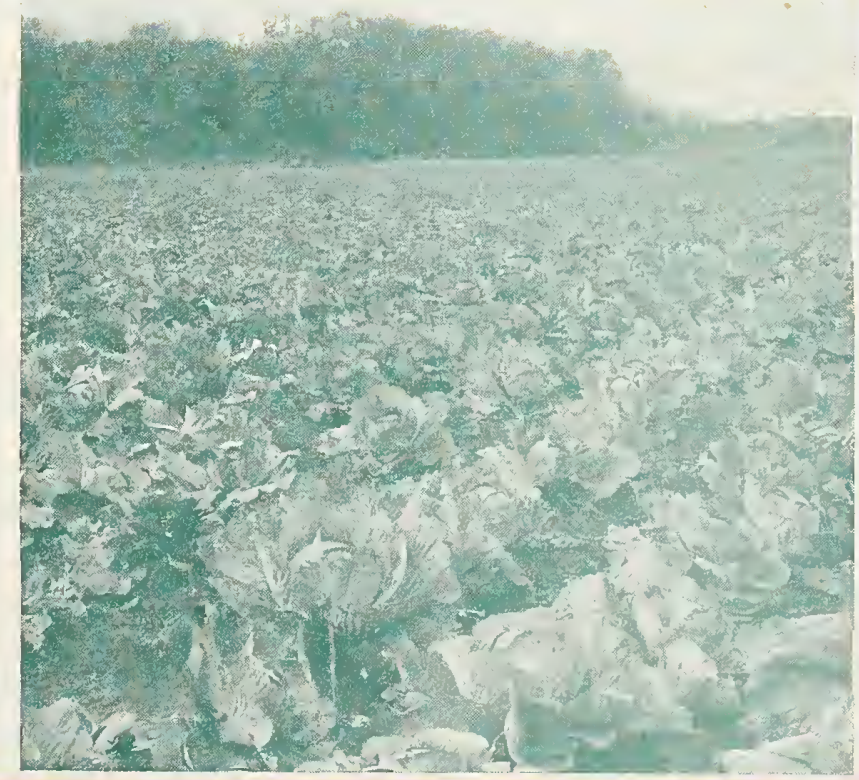


We will consider it a special favor if you write below the names of some of your friends who use Seeds:

\begin{tabular}{c|c|c|c|c|} 
Names. & Postoffice. & County. & State. & R. D. Box \\
\hline & &
\end{tabular}

\section{PARCEL POST}

\section{DOMESTIC PARCEL POST RATES.}

On Seeds Plants. Bullhs, Ronts. Bonks Tools etc.. wlthin the $\mathrm{L}$. S. and P'ossi'ssjons.

First Zone First Znne Thiris Zone Foivin Zon Fifth Zone Sixtih Z,inf
Siventh Zom Sirvinth Zon
Eightb Zone

\begin{tabular}{|c|c}
$\begin{array}{c}\text { First } \\
\text { pouncl or } \\
\text { frartion. }\end{array}$ & $\begin{array}{c}\text { Each } \\
\text { arditional } \\
\text { poincl or } \\
\text { fraction. }\end{array}$ \\
\hline $5 c$ & $1 c$ \\
$5 c$ & $1 c$ \\
$6 c$ & $2 c$ \\
$7 c$ & $4 c$ \\
$8 c$ & $6 c$ \\
$9 c$ & $8 c$ \\
$11 c$ & $11 c$ \\
$12 c$ & $12 c$
\end{tabular}

\section{IMPORTANT}

We supply with this ratalogue a roturn envrlope, in which you Mnn'y order, Fxpress llon'y nrdir or l3ank Draft nied not he registired Postage stames taken the same as mon'y in any a mount.

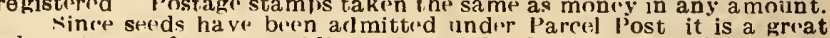
advantage to farmers residing many miles from a railroad as sereds and other article's ran' he delivered to their door, this saving a trip to town Bisidis. the rates are very reasonahle un to 4 in or 5 in miles Shnuld you wish to order large quantities of seeds by Parcel Post. write for special prices.

\section{READ THIS}

These seeds are all grown especially for us and are fresh, genuine and reliable. We handle no rommiss on sereds

Seeds of the best qual ty often fail to germ nate by reason of improper planting. weather cond tons. etc. in fact. most fa lures are from disregard of necssary cond tions and s nee thise conditions are so varied and so far hegond our eontrol. it s impract cable for $u s$ to in any way guarantee crop results, and while we exercise every care in reason. we ge no warranty. express or $\mathrm{mplicd}$ as to description. qual ty. product veness or any other matter of any seeds. and will not be $\mathbf{n}$ any way respons ble for the crop. If the purihaser does not accept the goods on these terms, they are at once to he returned.

Market Gardeners, or other large planters. requiring larger quantities of seeds than are here offered. are invited to wr te us for Special Prices, and must be sure to name varietles and quantities they will want.

Please bear In mind that the prices given in th's book include cost of nostage. except where noted For Peas Brans and Corn. add proper amount as shown by parcel post tahle to cover postage. If purchasers drsire forwarded hy express. they may omit the amount requ. red for postage.

Seeds by Express or Frelght. We deliver seeds to any express or railroad company, the purchaser to pay transportation charges upon receipt of goods.

Name, Address, Etc. When ordering please give your name and full address. Many orders reaeh 11 on whieh the name or postoffle address is larking lt is. of course, impossible to fll these orders untll they are Identifled

How to Send Money. Money ean be sent at our risk, either by nostoffice order, hank draft express order cr registered letter. If your order amounts to $\$ 1$ or more, it is hest to send hy one of the ahove methods. Postage stamns received the same as eash. Always be sure to sign your name. postofilce, county and state. Cash should always accompany the order.

\section{A Few Words About Irrigating the Home Garden}

In seed heds, where small seeds are sown thickly, it is necessary to sirinkle the beds, ne er flood them. During the winter months sprinkle o.aly in the morning when the water is warmer than the dew. This allows all the heat that arcumulates in the soil during the day to be retained far into the night. During the hot summer months it will he neressary to sprinkle in the evening to revive the plants after a hot day.

When making a garden, whether for drilling or planting seed or setting plants. always wet the ground thoroughly. GIVE IT 4 GOOD SOAKING TI A DEP'THOF TIVO OR'THREE FEET $O R$ IORE. As soon as it is tillable-that is. as soon as it ran he soaded and pulverized, or when the soil will not stick to the spadedig $i_{u}$ ten to twelve inches deep. put stable manure into every other furrow and turn it under. This is needed for humis and fertilizer, either in sandy or loamy soil and more esperially in adohe soil. Pulverize the s.il thoroughly and rake it evenly. mis. plant seed from one-fourth inch to one inch deep. in heary Soil and a little more depoly in sandy soil. Planted this way almost any variety of seed will germinate and show above the ground i 1 from four to ten days without irrigation. Never sprinkle a new garden befire the plant is ahove ground. nor after. if you can irrigate b t veen the rows. It is far better to irrigate than to sprinkle and much less labor. Always mulch the soil after each irrigation as soon as it mulches readily, hut no sooner. To allow the soil to To sprinkle the garden slightly each day during the summer months is of little value unless the ground is also thoroughly irrigated once each week or two, according to the nature of the snil Slight sprinkling refreshes the foliage, but may not penetrate the soil more than one inch deep. Thus as the under sojl diries. the roots get no moisture. The niants s'lfer and vnll do not sisneft the callse hecause you sprinkle each day. This is a common fault and the cause of many lidiures.

\section{A Word About Sowing Seeds}

Trany seeds are small and the germination weak; therefore, sow them very shallow, often not more than one-eighth inch deep. This is bocause the germ or sprout must have air and light. If this is denied by too deep sowing. it dies before it reaches the surfare.

In order to assist small or weak seeds to grow it is ad isable to plant plentifully because the many seeds will give strength to raise the sill where one could not do so.

This ad lce applies particularly to beet and melon seeds. but is applicable to a l small seeds. It is easy to thin out the surplus plants. A good general rule is to olant seeds to a depth equal to from three to five times their diameter. 


\section{SEEDS, BULBS, PLANTS, GARDEN AND POULTRY SUPPLIES}

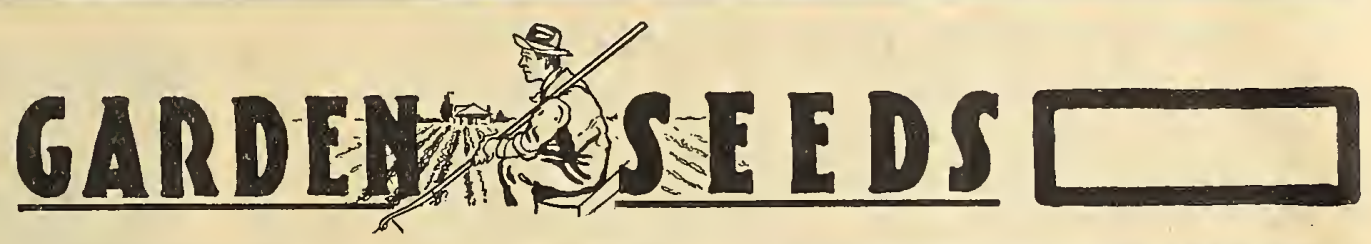

\section{DON'T GIVE UP YOUR WAR GARDEN}

Now that the war is over there will be many that will forget about their gardens. Don't do it. These times of high prices for all vegetables makes it very profitable for both the Home Gardener and the Market Gardener to PLANT MORE.

\section{ASPARAGUS}

Sow one ounce for 60 . feet of drill, in rows 1 foot apart. When two years old transplant into permanent beds, which should be well and deeply manured, and trenched to the depth of 2 feet. Set the plants (in rows) from 3 to 4 feet apart, and 2 feet in the rows, spreading out the roots and covcring from 6 to 8 inches. On the approach of winter cover with manure
or compost; fork the beds early in the spring and apply a dressing of salt. Cut for use the second year after planting in permanent bed.

\section{ASPARAG US SEED}

Succeeds well in any good, rich soil, but a light, warm soil which has been heavily manu ed for previous crops is best.

GIANT ARGENTEUIL.-Originally a selection from imported French stock, but has been both acclimated and improved, and is much superior to the original stock. It has been grown for several years by the most successful truckers and is pronounced far superior to any other variety in earliness, productiveness and size and always sells at a higher

PALMETTO. Although of southern origin, it is well adapted to the North and it is extensively grown for the markets; it brings high prices, owing to its large size, beautiful color and regularity of stalk. Pkt., $5 \mathrm{c}$; oz., $10 \mathrm{c}$; $1 \mathrm{~b}$., $75 \mathrm{c}$.

\section{DWARF BEANS}

CALLED STRING BEANS, BUSH BEANS AND SNAP BEANS.

One quart to 100 feet in drills, or 150 hills: $11 /$ bushels to the acre, in drills. Mature for table use from 30 to 50 days from germination, according to variety.

CULTURE.-Plant from end of December, and for succession, every two weeks unti May. Beans planted in this latitude during June and July will not produce much. August and September are good months in which to plant again. They are ready for the table in from thirty to fifty days after planting. Beans do not require heavy manuring; in fact, if the soil is fairly good, it is better to use a good fertilizer. The fertilizer should be well mixed in the furrow with the soil before the Beans are planted. For field culture plant in rows $2 \frac{1}{2}$ feet apart and about 3 inches between the Beans, covering the seed to a depth of about 3 inches. If to be cultivated by hand in small gardens, the rows may be 18 inches apart. Up to the time of blooming cultivate often.

Prices on Beans, quarts or less, postpaid.

\section{GREEN PODDED BEANS}

GIANT STRINGLESS GREEN POD.- Somewhat similar to Burpee's Stringless, but pod is a little longer, straighter and more slender, more depressed between beans and slightly lighter in color; early, hardy and of highest quality. Pkt., 15c; $1 / 21 \mathrm{~b} ., 25 \mathrm{c} ; 1 \mathrm{lb}$., 40c; 2 lbs., 75c; 15 lbs., $\$ 3.75 ; 60$ lbs., $\$ 14.50 ; 100$ lbs., $\$ 22.50$. FULL MEASURE. A f fine stringless, early, dark green, high

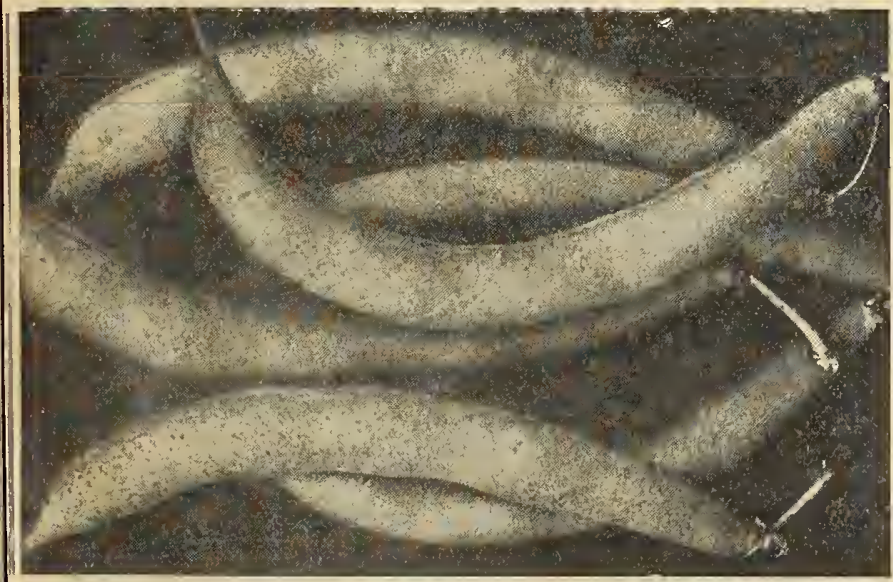

I mproved Red Valentine Beans bean much resembles Red Valentine. Pkt., 15c; 1/2 lb., 25c; $1 \mathrm{lb.}$ 40c; 2 lbs. $75 \mathrm{c} ; 15$ lbs., $\$ 3.75 ; 60$ lbs. $\$ 14.00 ; 1001 \mathrm{bs} ., \$ 22.00$. best; earlier than the old Early Red Valentine. The vine is dwarf. the pods are smooth, round, stringless and very thickly set, remainin green and tender a long time after they are fit to pull. Vine ver uniform, making little or no top growth, and producing enormously - the great market-garden, green-colored snap bean. Qt., 65c peck, $\$ 3.50$; bu., $\$ 13.50$.

- LONGFELLOW.-A superior type of green-podded snap bean; early hardy, prolific, round pods of attractive appearance. Qt., 65c; peck, $\$ 3.50 ;$ bu., $\$ 13.50$

EXTRA-EARIY REFUGEE.-Has all the good qualities of the well-known Refugee, but is ten days earlier. Very productive, and sure to produce a crop either in a wet or a dry season. A fine shipper, and fast becoming one of our most popular round green-podded snaps for both spring and summer planting. This Bean is always sure of bringing the very best prices in market. Qt., 65c; peck, $\$ 3.50$; bu., $\$ 13.50$.

REFUGEE, or 1,000 to 1.-One of the best snaps for main crop and late or succession plantings It is enormously procrop and late or succession plantings. It is enormousiy protable qualities. Later than the early kinds, but continues in bearing much longer and is more productive. Qt., 70c; peck, $\$ 4.25 ;$ bu., \$16.00.

BURPEE'S STRINGLESS GREEN POD.-Claimed to be hardier and will stand frost better than any other early kind and that it is entirely stringless. It makes a round-podded snap, tender and of excellent quality, Qt., 60c; peck, $\$ 3.75$ bu., $\$ 14.00$.

BLACK VALENTINE.-This variety is becoming more popular each season. It is very hardy and will stand more frost and cold weather than other kinds and consequently can be planted earlier with less risk of injury by cold. It is fully as quick-growing as the Red-speckled Valentine, very productive and makes round, straight, tender pods of attractive appearance both for market and home use. Qt., $65 \mathrm{c}$; peck, $\$ 3.75 ;$ bu., $\$ 13.50$. 


\section{E. A. MARTIN SEED COMPANY, JACKSONVILLE, FLORIDA}

\section{WAX-PODDED BUSH OR SNAP BEANS}

DAVIS WHI TE KIDNEY WAX.-Pods remarkably long, straight and of a handsome waxy white color; enormously productive, Seed white. Write for price.

WAR heavy crops of long, showy pods, tender and of the finest flavor. vigorous grower, bearing up well bringing top prices. Is remarkably free from rust. $0 t .65 \mathrm{c}$. 1n shipping, it stands

DWARF GOLDEN WAX. - An old, well-known favorite variety for private gardens. Pods long, semi-round, golden yellow and very fleshy and of the best quality. Qt., 65c; peck, $\$ 4.00$; bu., $\$ 15.00$.

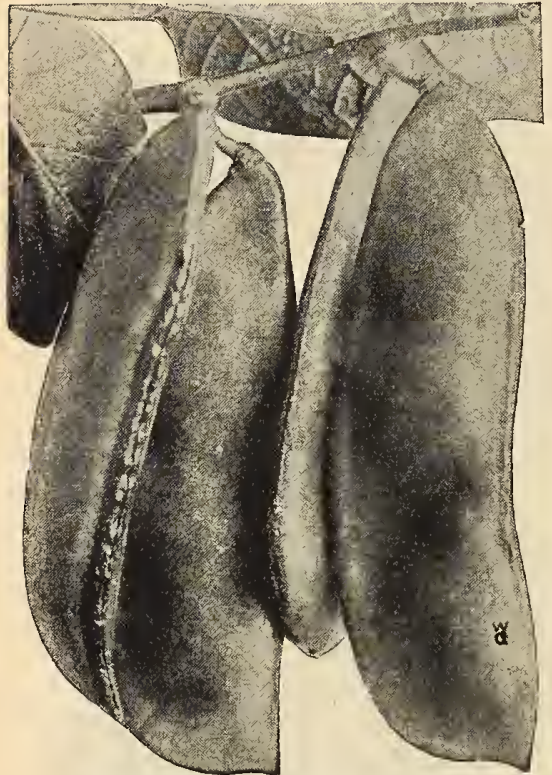

Fordhook wush Lima Beans

\section{Pole or Running Beans}

\section{ALMOST THE ENTIRE YEAR.}

One quart to 150 hllis, 10 to 12 quarts to the acre in drills. Matures for table use from 48 to 85 days from germinatlon.

These are more tender and require rather more care in culture than the Bush Beans and should be sown two weeks later. They succeed best in sandy loam, which should be liberally enriched with short manure in the hills, which are formed acm cording to the variety, from 3 to 4 feet apart. From five to six seeds are planted in each hill, about 2 inches deep. As the matured Bean is used mostly the season is too short for succession crops in the North though it is advantageous to plant succession in the southern sta tes, especially in Florida in the sjuthern states. especially in Florida, where the season of growth is almost the entire year. Rough cedar or similar poles about 7 or 8 feet high should be used for Lima Beans to cli mb on. They should be prevent being blown over.

KENTUCK Y WONDER. - The most popular of all Pole Beans, especially in this pods are immense, often attaining a length of 9 to 10 inches and borne in large clusters. Bright green, very meaty, tender and stringBright green, very meaty, tender and stringless when young. assuming a saddleback depth, and becomi ng somewhat irregular and spongy as the Berans ripen. Very early. Qt.,
$65 c$; peck, $\$ 4.50$; hu., $\$ 17.00$.

OLD HOMESTEAD. - This we regard as far ahead of any of her green-pod Pole Bean. is ten days earlier; enormously productive and entirely stringless. Qt., 65c; peck, \$4.50; bu., $\$ 17.00$

LAZY WIFE. - So named on account of the large number of pods it affords, making it easy to obtaln a supply. One of the best varieties for snaps of the late green-podded Pole Beans. The pods grow in large clusters, are 5 to 7 inches long, broad, thick, fleshy and entirely stringless. They have a rich, buttery flavor. The dry Beans, which are white, are_flne for winter use, Sold out.

The quality is remembered long after the price is forgotten.

\section{DWARF OR BUSH LIMA IB]EANS}

\section{Mature earller than Pole Llmas.}

One pint of small-seeded sorts plants from 100 to 125 feet, and is sufficient for an ordinary garden, or one quart of the large seeded sorts. For succession. make two plantings, four weeks apart. Mature in from 75 to 80 days from planting.

SPECIAL INFORMATION ON LIMA BEANS.-Our personal experience and observation has proven to us that it will pay, in planting the large varieties of Lima Beans, to be particular and place the eye down when planting. When beans germinate they force the bean upwards and out of the ground and when the eye is ul, this compels the sprout or germ to grow under the bean to force it out of the ground and often this breaks the sprout and causes failures which are sometimes attributed to bad seed and other causes. We are the normal size and weight. This especially applies to the Furd hook variety.

BURPEE'S IMPROVED BUSH LMA. - Bush form of the well-known Large Llma, and although not so early as the preceding variety, the large size and excellent flavor of the Beans make it desirable. Qt., 75c. Write for Prices in Quaritity.

HENDERSON'S BUSH LIMA.-This variety has enjoyed great popula rity. They are two weeks earlier than the Pole Limas and wonderfully prc iductive, averaging about sixty pods to the bush, bearing three to four sm all Beans. Of hardy growth, very proliflc and continuous in bearing till frost. $Q t$. $60 \mathrm{c}$; peck, $\$ 4.50$; bu, $\$ 16.00$

FORDHOOK BUSH LiMA. The Beans of this new varlety are of the large lima type, but are thicker and rounder, and of superior flavor. Th $\theta$ bush itself is of stiff, erect habit, holding the Beans well off the ground, so that the pods do not become discolored or injured from being beaten to the ground by wind or rain. It is also very prolific and the pods contail from four to five large, fat Beans each. lying closely together. The pocts are so closely packed that the Beans are very easily shelled. The green Beans, even when of full size, are tender, juicy and sweet of flavor when cooked. We recommend this new introduction to our customers as a thoroughly distinct and valuable lmprovement in Bush Llmas. Qt., 75c; pec $k, \$ 4.75$; bu., $\$ 18.00$.

POLE LIMA OR BUTTER BEANS.

LARGE WHITE LIMA.- Elther green or dry, this is the standard table vegetable, and the best shell Bean known. Give it rich ground and plenty of room. Qt., $65 \mathrm{c}$; peck. $\$ 4.50$ : bu., $\$ 17.00$

SMALL LIMA, or SIEVA. - Similar in every way to Large Lima, except that it ls only half as large, seeds and pods being smaller. Largely grown in the South and immensely popular. Qt.. 75c; peck, $\$ 4.50 ;$ bu., $\$ 17.00$.

Our beans are grown for us by the most rellable growers very best to be obtained. 


\section{CAREFULLY MARTIN'S HY TE ST BEETS SURE TO TESTED MARTIN'S HY-TEST BEETS GROW}

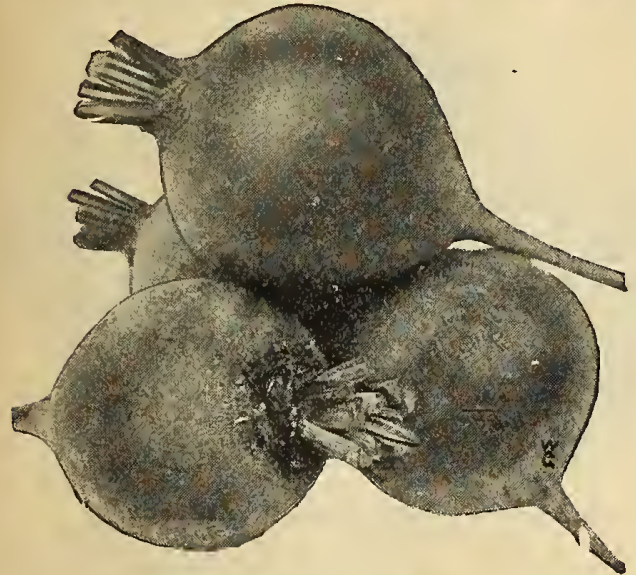

Martin's 'DarkRed "Beets

Two ounces will sow 50 feet of drll1, 6 to 8 pounds one acre. Mature for table use 35 to 60 days from germinatlon.

CULTURE.-The ground for Beets should be rich and well spaded or plowed. In this latitude Beets are sown in January to May, and from the first of August to December. Some market gardeners sow them every month in the year. Seeds should be soaked twelve hours before planting as this softens the bur and allows the seed germ to prove itself much quicker. For field culture, sow in drills 2 to $21 / 2$ feet apart, and cover a bout 1 inch. Thin out to 4 inches apart. For a small garden, the drills need not be more than 15 inches apart.

Prices on all kinds of Beets are by mall, postpald.

IMPROVED EARLY BLOOD TURNIP.-Dark red, smooth, uniform size and of excellent quality. One of the best for main crop. as it keeps in condition longer than the other kinds. Pkt., 10c; oz., 15c: $1 / 4$ lb..40c: $1 \mathrm{lb} . \$ 1.25$.

EXTRA-EARLY EGYPTIAN BLOOD TURNIP.-An old standard sort both for market gardeners and family use. Produces fine. smooth, deep red roots. About ten days earlier than the Blood Turnip. Pkt., 10c; oz., 15c; 1/4 lb., 4Jc; lb. $\$ 1.40$.

Extra Early Ecllpse.-A most popular market gardener's Beet for the South, as well as a favorite for home gardens. Of remarkably fine form, smooth and free from stringy roots. Small top and a rapid grower. Color a deep blood red, which it retains fully and after being cooked. Quality extra fine, sweet and tender. A heavy cropper, and its handsome appearance makes it an easy seller when placed on for fall planting. Pkt.. 10r: oz., 15c; $1 / 4$ lb., $40 \mathrm{c}$; lb., $\$ 1.35$.

MARTIN'S DARK RED.- The King of Béets. A blood-red, early, turnipshaped variety. Has small, upright tops: fine round shape; skin and flesh dark shaped variety. Has small, upright tops: fine round shape; skin and fiesh dark desirable sort for truckers and market gardeners. Pkt., 10c; oz., 15c; 1/4 lb., 40c; lb., $\$ 1.50$.

LONG SMOOTH BLOOD.-Long, smooth and very dark red; a late variety. Our strain of this variety cannot be excelled, and will produce perfect beets, which will always

be in demand in market. Pkt., 10c; Oz., 15c; 1/4 lb., 35c; lb.. \$1.25. for early market in the South than any other lind. It takes on its turnip shape even in early stages of its growth, a decided advantage both for forcing and early cropping. Pkt., $10 \mathrm{c} ; 0 \mathrm{z} ., 15 \mathrm{c}$. $1 / 4$ lb., $43 \mathrm{c} ;$; lb.. \$ 135

LENTZ; EX TRA EARLY BEET.-Small top, round dark red, and grows large, but is always sweet and tender; a good winter sort

Some market gardeners claim this beet ean be raised for market in a shorter growing time than any other variety. A great favorite in Florida for shipment to northern

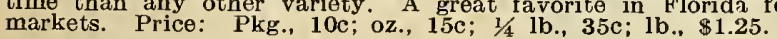

\section{Swiss Chard or Spinach Beet}

The stalks when cooked and served like asparagus make a most delicious salad. The leaves sh uuld be prepared like spinach, kale or turnip salad. Sown early in the spring it yields salad all summe : Grow a row and you will not be without it hereafter. Pkt., 10c; oz., 20c; 1b., \$1.50.

\section{MANGEL-WURZELS}

SIx to elght pounds of seed will sow an acre.

CULTURE.-The following varieties are extensively grown for feeding stock, and are excellent food to increase the flow of milk. As they grow much larger than the varieties cultivated for table use they require more room, and should be sown in dills about 2 feet apart. The seeds should be dropped about 2 inches apart in the drills, and $w$ hen strong onough, thinned out to 12 to 15 inches in the drils, and when strong enough, thinned out to 12 to 15 inches in the
row. The long varieties are best suited to a deep soil, and the globe row. The long varieties are best suited to a deep soil, and the globe
sorts succeed better than the long sorts on sandy soil. Study your

Prlces on all varletles of Mangel-Wurzels as follows: Pkt., 10c; oz., 15c; lb., \$1.00.

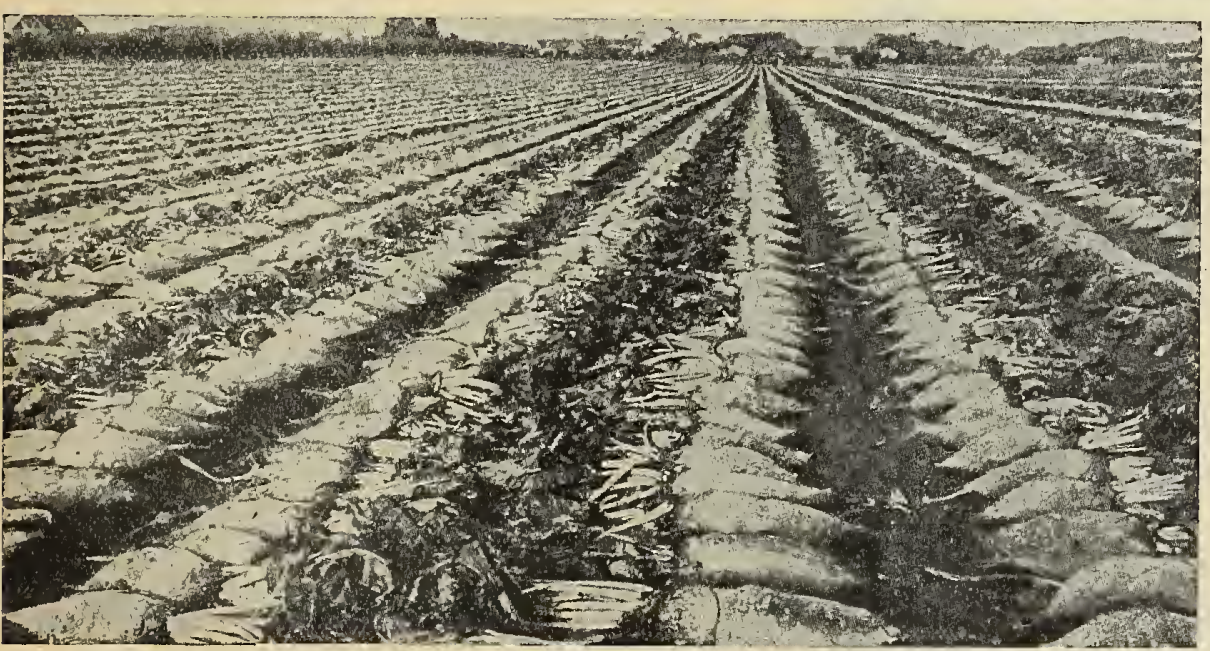

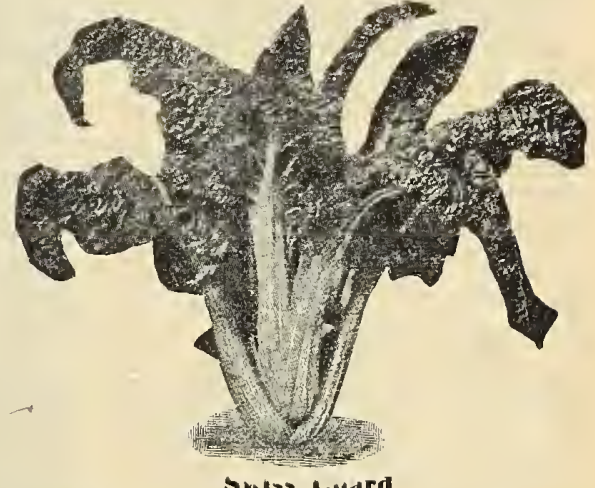

brotso Catard

LARGE RED GLOBE. -Globe-shaped; red; similar to 'Yellow CHAMPION YELLOW GLOBE.-The best Yellow Globe Y yielder, splendid keepor. of to 50 tons per acre; quality superior; the best for deep soil.

\section{BRUSSELL'S SPROUTS}

One ounce will produce about 3,000 plants.

Of the cabbage family, producing numerous heads on the stem of most delicious quality, as well as cabbage-like head at the top Use and cultivate the same as winter cabbage.

PERFECTI ON.-A new and great ly superior variety of American growth which forms hcads ready for picking about three weeks earlier than other varieties. It makes stronger plants and more heads. A profitable crop for market gardeners. Pkg., 10c oz., 50c; lb., $\$ 6.50$.

\section{BROCCOLI}

Requlres a longer season than elther cabbage or caulifiower to develop: TURE — The same cultivation as suggested for caulitlower should be given to Bruccoli.

bete CAPE. - The compact and hard, and it is a hardy, vigorous and easily grown sort Pkt, 15c: 1/2 oz., 40c; oz., 75c.

Do not fall' to Include In your order Martln's Dark Red Beet, an exceptionally fine varlety which will most certainly please you. 
For cutting matures 65 to 120 dyys, according to variety.

CULTURE.-Have soil in your bed in the best possible condition. Do not make it too rich or your plants will grow quíckly and consequently be weak. Such plants will not stand the shock of transplanting. Soil that has been manured the previous year is to be preferred. Seed should be drilled 6 inches apart, and not too thick; cover lightly and press the soil down firmly around seed. Keep plants watered and free from grass For weeds. Plant during February and Varch; again in fuly and August. ounces of seed will supply enough plants to set one acre. We advise rows $21 / 2$ feet apart with plants 18 inches apart in the row.

All prices are mail, postpaid.

MARTIV'S EARLY SUWANEE CABBAGE.-Quickest maturing flat-head cabbage in existence. We offered this wonderful variety for the first time last fall. Our supply was so short that we did not list it in our fall catalog, but later offered to the Florida planter our surplus stock through our weekly price list. We also sent out trial packages all over the South. We are now getting very complimentary reports from e rery section. Farly Suwanee will mature about twelve to fifteen days earlier than Jersey Wakefleld. Heads are very firm almost round but slich than Is not only are very frm, almost round, but slightly hattened on top, Is not only a quick maturing variety, but the leaves are very tinely webbed garden or for market, our suggestion is, plant Early Suwanee Cabbage. garden or for market, our suggestion is, plant Early Suwanee Cabbage.
But to do this it will be necessary for you to get your order in EARLY. Pkt., 25c; oz., 50c; $1 / 4$ lb., $\$ 1.75$, lb., $\$ 6.00$

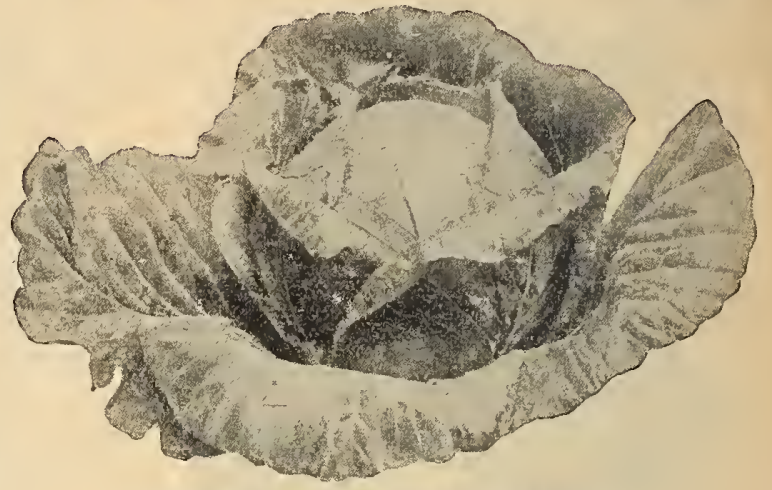

ALL-HEAD EARL Y.-. M' any of our local gardeners are having great success with this variety. Especially recommended on accoun $\dot{s}$ of its uniform size and shape and reliability for heading; makes a deep, flat head, solid and uniform in color, shape and size. In tenderness it is unsurpassed. Can be grown either for summer or winter use. By reason of its compactness it can be planted closer and will yield more heads to the acre than varieties of a more spreading habit. Pkt., 10c; oz., 30c; $1 / 4$ lb., \$1.00;

\section{COPENHAGEN MARKET.} Very fine, nearly as early as Wakefield with large, round, solid heads, Crop failed. Pkt., 15c; oz., 40c; $1 / 4$ lb., $\$ 1.50,1 b$ CHIVES $\$ 5.75$ CABBAGE.

CHIVESE CABBAGE. - The kind of cabbage universally grown in China. Does not head up solid like our Cabbage, but makes a loose roll of leaves, tender and white, but Stems are thick and brittle like celery. It is better to be blanched by tying up the outside leaves around the plant. A great curiosity and really a delicious vegetable. Pkt., 10c, oz. 35c; $10 ., \$ 4.50$ TED EARLY JERSEY WAKEFIELD. - A favorite sort with market gardeners and truckers to

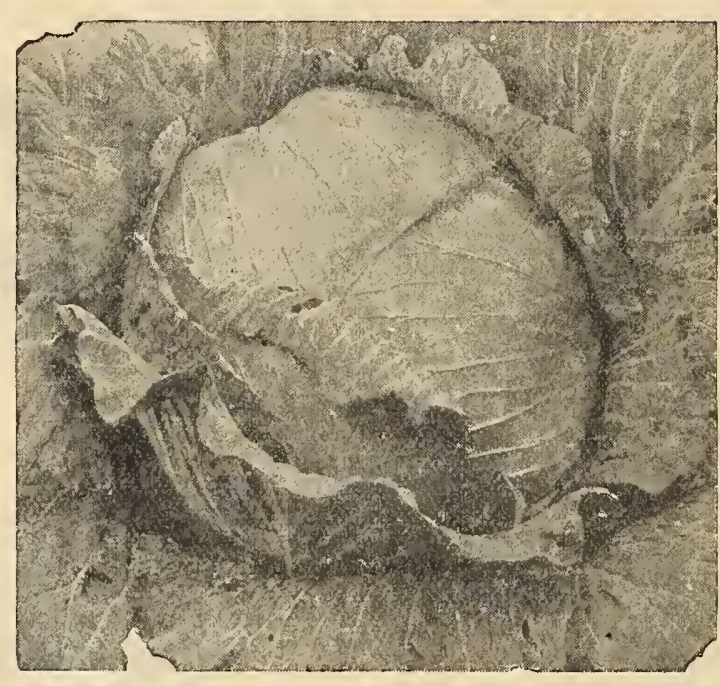

Succession Cabbage grow for earliest Cabbage, both for home market and for shipping Makes compact, solid, blunt-pointed heads; small leaves, permitting close plant-
ing. Very hardy, not only to resist cold, but other unfa vorable conditions, insuring the greatest likelihood of profitable and satisfactory results. Our stock is grown and selected with the grcatest care. Pkt., 10c; oz., 35c; $1 / 4$ lb., $\$ 1.25 ; 1 b ., \$ 4.00$.

EARLY DWARF FLAT DUTCH. - One of the most reliable cabbages for early spring planting. Plant is short-stemmed, upright, and. haling comparatively fow and short gether. Hcads large, solid crisp and tender. Pkt., 10c; oz., 30c, $1 / 4$ 1b.,
$\$ 1.00 ; 1 b ., \$ 3.50$.

IMPROVED EARLY DRUMHEAD. - An intermediate kind between the cone-shaped early and late varieties; can be planted closely, takes name from its shape. Pkt., SUCCESSION. - Largely a market gardener's variety in many parts of the South, being used almost exclusively for shipping crops. Rather large size, well flattened on top. In maturity, almost ten days later than barly Summer and Early Flat Dutch, but nearly double the size of those
varicties. Firm and solid, a very

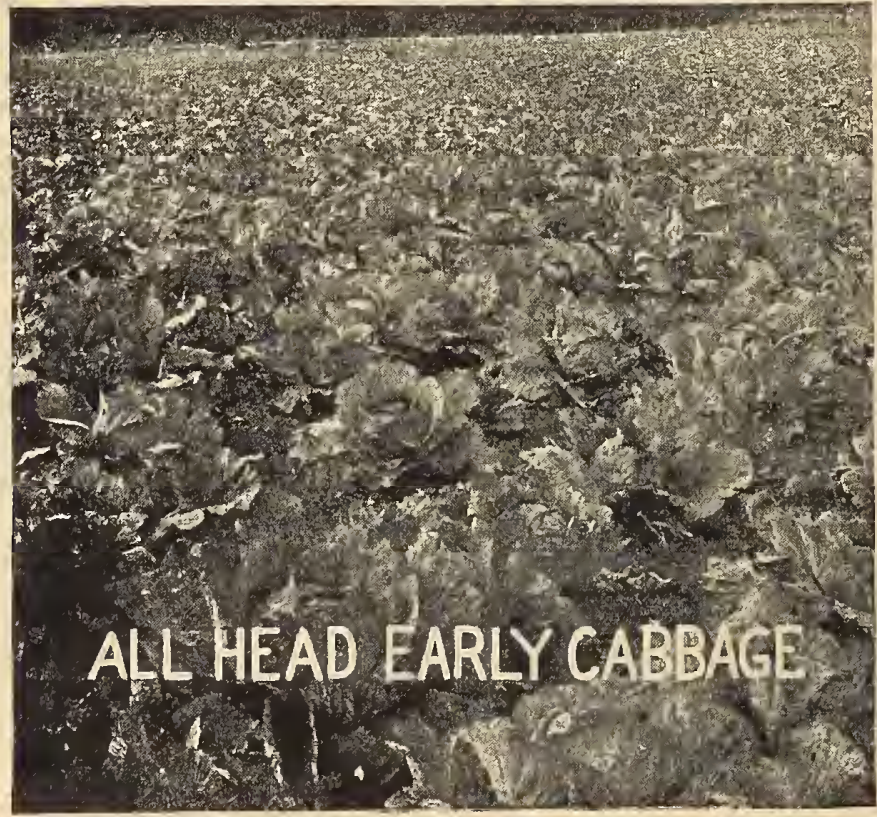

sure header and stands shipment to the North, arri ing in good condition and color. Succession is a good variety and a favorite in many parts of Florida. Pkt., 10c; oz., 3jc, $1 / 41 b ., \$ 1.00 ; 1 b$. ,

FED ROCK (Henderson's $\Lambda^{r}$ ammoth). - The largest and surest-heading l'ed cabbare. Heads as lar and $s$,id 25 . lat FLORIDA HEADkm. One of, 35 , $1 / 4 \mathrm{lb}$., 1.25 , $10 ., 54.50$. or For seculad-ealy surelv. It is a true, sure, hard header. $\mathrm{Pkt}$., 10c, oz., 30c, 1/4 lb.,

PREMIUM LATE FLAT DUTCH.-As a variety for winter nuarket this Cabbage has no superior. Heads are large, round, solid, broad and flat on top, often tinted with reddish brown after being touched by frost. They open white and crisp, are tcnder and wcll flavored. It is a fall and winter variety and one of the best keepers. With good cultivation on moist, rich ground, 95 per cent of them will head up. Decidcdly one of the 30c; $1 / 4$ lb. $\$ 100$ lb $\$ 3.50$

HENDERSON'S EARLY SUMMER.-A favorite roundheaded variety. Pkt., 10c; oz., $35 \mathrm{c}$; $1 / 4 \mathrm{lb} ., \$ 1.00$; lb., $\$ 3.75$. Heads the list for winter use. Pkt., $10 \mathrm{c} ; 0 z, 30 \mathrm{c} ; 1 / 4 \mathrm{lb} ., \$ 1.00 ; 1 \mathrm{lb}$., \&3 75. CHARLESTON WAKEFIELD. This is a few days later than the Jersey Wakefield but makes a larger and more solid head Pkt, 10c; oz. 35c; 1/4 1b, \&125; 1b., \&.00. FINE EARLY WINNINGSTADT. One of the best for
er early or late use. Pkt., 10c; oz., $3 \mathrm{cc}, 1 / 4 \mathrm{lb} ., \$ 1.00 ; 1 \mathrm{~b}$. , $\$ 3.50$. $A R G E$ LATE DRUMHEAD.-A favorite winter cabbage.

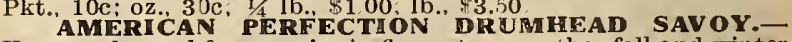
Very tender and far superior in flavor to any other fall and winter cabbage. Pkt., 10c; oz., 35c; 1/4 lb., \$1.25, 1b., \$4 50. 


\section{MARTIN'S CARROTS}

Two ounces will sow 100 feet of drill, 3 pounds required for an acre. Matures about 60 days from germination.

CULTURE.-Carrots require a very finely pulverized soil to grow them to perfection. A good, light. well-enriched sandy loam is the best for this crop. For field culture, sow in dills 3 to $31 / 2$ feet apart. so as to culti rate by $h$ rse. crops, cover $1 / 2$ inch deep and thin to 6 inches in the rows; for late, cover $1 / 2$ inch deep and thin to 4 inches.

Chantenay Half-Long.-A new stump-rooted French variety, the best of its class. I nexcelled in producti eness and quality. Vcry uniform in growth. Roots early and fine for both market and home gardens. Pkt., 10c; oz., 15c; $1 / 4$ lb., $50 \mathrm{c}$ lb., $\$ 1.50$.

DANVERS HALF-LONG.-One of the heaviest croppers: roots dark orangecolor, 8 to 10 inches in length, thick and ending in a somowhat abrupt point. Pkt. $10 \mathrm{c}$; oz., $15 \mathrm{c}$; $1 / 4$ lb., $40 \mathrm{c}$; $1 \mathrm{~b} . . \$ 1.25$.

EARI,Y SCARLET HORN.-Popular early variety. Color a deep orange, of a most delicious flavor and makes a most splendid crop in light, shallow soils. A favorite in both market and home garden. Roots 4 to 5 inches long. Pkt., 10c; oz., 20c; $1 / 4$ lb.. 50c; lb.. $\$ 1.75$.

OXHEART, or GUERANDE.-Deserving of general cultivation. It grows 3 or 4 inches in diameter, is early, nearly oval in shape. Pkt., 10c; oz., 15c: 1/4 lb., 50c; lb., $\$ 1.50$.

RUBICON.-Half long and stump rooted: color deep orange: finest quality. Pkt., 10c; oz.. 20c; $1 / 4$ lb., 50c; 1b.. \$2.00.

IMPROVED LOVG ORA VGE. - Especially fine on lizht soils, making long smooth tapering roots of a deep orange-color, and free from side roots: superior in every respect. A fine winter sort for table, market and stock. Pkt., 10c; oz., 15c: every respect. A fine

\section{CARROTS FOR STOCK}

CULTURE.-Sow 3 pounds to the acre. These roots are often 15 inches in circumference; greatly enjoyed by stock and gives fine color to butter. 500 bushels can he raised on one acre. 1 bushel is equal to 1 bushel of corn in feed value.

BELGIAN YELLOW. - Largest. heaviest cropping and most nutrifious yellow variety in cultivation. Easily gathered as the roots grow largely above the ground. Pkt., 10c; 0z.. 15c; $1 / 41 \mathrm{~b}$, $30 \mathrm{c}$; lb., $\$ 1.25$.

\section{COLLARDS}

CULTURE.--One ounce will produce about 2,030 plants. or 150 feet of row. Sow in soring. or s.mmer. as directed for cabbage. either in beds. to transplant when large enough. or in rows where intended to stand. They are rapid growers.

NORTHI CAROLINA SHORT-STEM.-A decided improvement, and has proved very popular where grer grow. Has short stem. large, spreading leaves, very hardy, withstanding drought. in summer and cold in winter. Its fiavor and cooking qualities are the very best. Pkt., 10c; oz., 1.jc: lb., \$1.03.

SOUTHERN, or GEDRGI4. -This variety is the old-time favorite. Stands all sorts of ad erse condi i ns withult injury. Is very hardy. In many places where the $s$ il is ton $p$ ) or to grow cabbage, the Collard grows easily and makes a good substitute for cabbage. 1'kt.. 5c; oz.. 10c; 1/4 lb.. 30r: 1b., \$1.00.

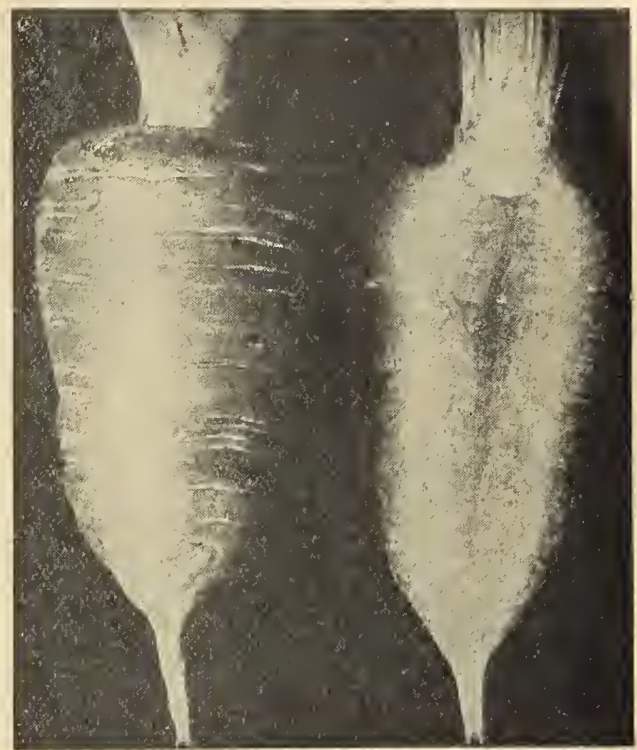

CUCUMBERS

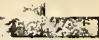

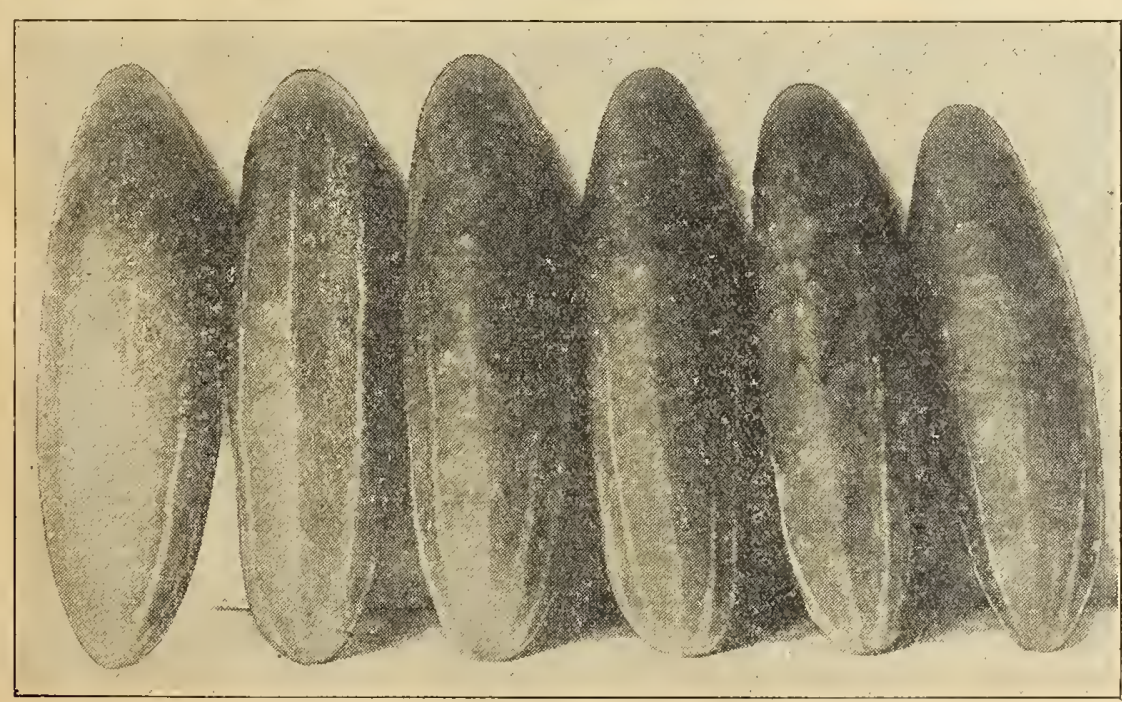

One ounce of seefl will plant 50 hills, 3 pounds to the acre. Matures from 36 to 50 days.

CULTURE. - For early ilse, plant as soon as the ground is warm in hills 4 to 6 feot apart each wav, ei zht to ten seeds in a hill. Cover $1 / 2$ inch deep. Whon danyer of inse ts is past. thin out the plants. lea ing $\mathrm{Ave}$ or sis of the strongest in each hill.

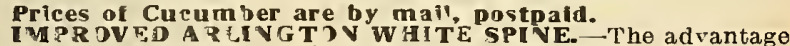
claimed for this variety are improvement in shape, color. earliness

and shipping tuali iss. Pkt.. 53: oz.. 15? lb. \$1.00. variety for shipping, Pkt., 5r:; oz., 15e; lb.. \$1.00.

inch long and inches thick: remains crisp a long time. It is a grand market sort. Pkt. 50: oz. 15c: lb. $\$ 1.25$. Crows 10 to 12 inches long, but makes ine pickles when young; the full-sized fruits are hest for sveet pinkles and sli ving. Dark gren in color firm and crlsp:

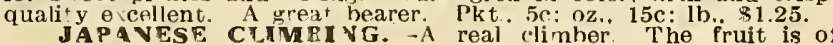
evtra quality and dark green. Proli $1 \mathrm{c}$ and a desirable table variety. Pkt., $5 \mathrm{c}$; oz.. $15 \mathrm{c}$ : Ib.. \$1.50.

green b., \$1.50. WEST INDIA GHERKIV. The only genuine Gherkin
oval covered with spines: lixht green. For plekling ex-

DAV'S PERFECT. - A superb variety: Dark glossy green, slim and symmetrical, with an average length of 10 to
12 in. They hold color till nearly rlje when 12 in. They hold color till nearly rlpe when they turn white without a yellow streak on when fit for table use. Very tender. brittle and of exceptional flavor, Farly as earliest strain of White Spine and outyields al

others. Pkt.. 5c: oz. 15c: lb.. \$1.25. and borne in pairs; lirht green. a grest bearer. Pkt. 5c: 07.. 15c: 1b. $\$ 150$. Wearer. $\mathbf{W}$ I T E : SPINE, HENDERSON'S PERFECTIED SA fine dark green selection of Arlingtion white Spine. Pkg., 5c: iz.. 15c: lb.. \$1.25.

MARKET GARDENERS AND LARGE FARMERS will find it to their advantage to write us for special prices on large quantities of seed. We carry a big stock at all times. 
One-fourth ounce produces about 500 plants; 2 ounces make enough to set out an CULTURE acre. Matures heads in 90 days from planting.

methods of cultivation will answer grow on soil well adapted to cabbage, and the same are sown at all seasons. They must be put out just as early as danger of freezing has passed. Rapid cultivation is necessary to bring the plants to head before hot weather. The heads will be improved if the leaves are tied over them when beginning to form.

HENDERSON'S EARLY SNOWBALL.-This is undoubtedly the finest variety ever introduced; it is the earliest and produces beautiful snow-white heads of the most deintroduced; it is the earliest and produces beautiful snow-white heads of the most de-
licious llavor. The seed we offer is pure and genuine. Pkt., 25c; 1/4 oz., 75c;oz., $\$ 2.50$; $1 / 4$ lb. $\$ 8.50$; 1 b. $\$ 33.00$.

1/4 lb, $\$ 8,50$; lb. $\$ 33.00$. A new variety and we think the best early, large-growing kind: forms a large head, which is solid, crisp and tender, and will form heads under unfavorable conditions more surcly than any other. Pkt., 25c; $1 / 4$ oz., 75 c; oz., $\$ 2.25$; $1 / 41 b .$, $\$ 8.00$.

\section{CELERY}

One ounce sows about 100 feet and produces about 8,000 good plants; 8 ounces to set one acre. Matures from 120 to 160 days.

CULTURE. - Celery requires a moist and fertile soil. If your soil is not fertile. you must make it so by heavy applications of well-rotted manure or commercial fertilizer. In Florida, sow seed for general crop from August 15 to November 15. Seed must not be covered more than $1 / 4$ inch and bed must be well shaded. When plants are from 4 to 6 inches high, cut tops off two or three times to make stocky plants. Transplant when 6 inches high into trenches and as the plants grow, keep drawing the earth up around them, to blanch the stalks for market.

GOLDEN SELF-ALAN CHING (French Grown).-Of compact growth, with larga, solid heart and thick-ribbed stalks, which blanch casily. Crisp and solid. Free from stringiness and of most delicious flavor. Both stalks and leaves are of a beautiful golden yellow. Pkt., 10c; 0z., \$1.25; lb., \$15.00.

BOSTON MARKET. - D warf branching variety, grown so extensively about Boston. Solid, crisp, and of excellent flavor; its compact, dwarf habit allows closer planting and requires less earthing up than taller sorts. Pkt., 10c; oz., 50c; 1b., \$7.50.

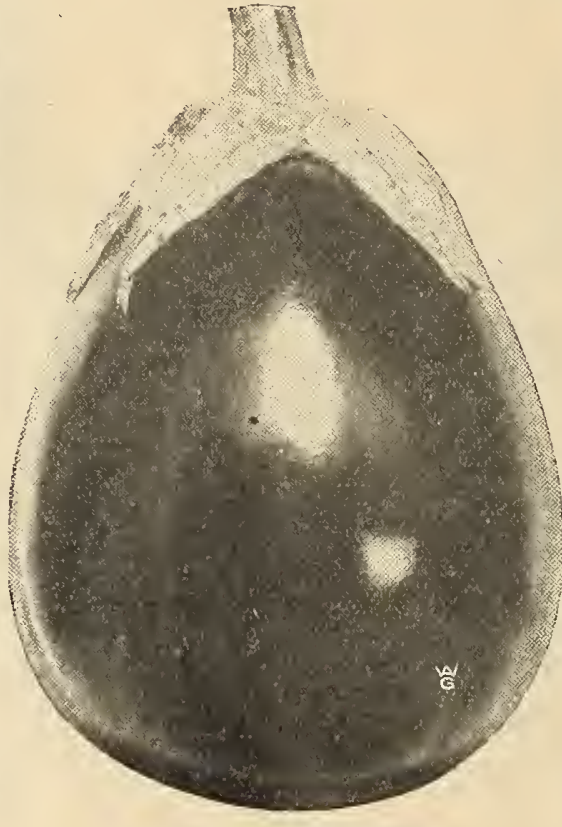

Black Beauty Eggplant

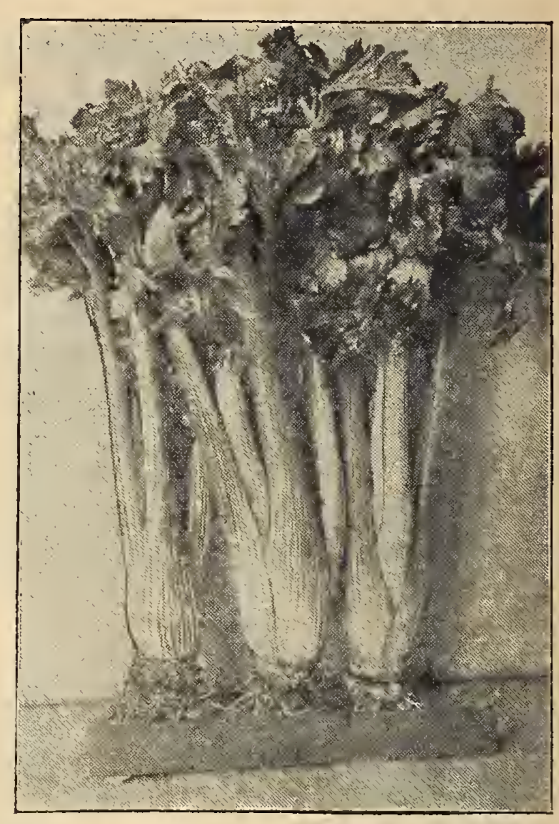

Golden Self-Blanchlng Celery

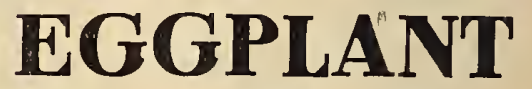

One ounce for 1,000 plants, requirse about 4 ounces to plant an acre. Matures In about 120 days from sowing.

CULTURE. - Eggplant seed germinates slowly and should be started in a strong heat. The soil should be one part leaf-mold and one part sandy loam. It is important to secure a rapid and continuous growth. Set 30 inches apart. pinch off the larger leaves when transplanting.

FLORIDA HIGH BUSH: $\rightarrow$ Rich purple: oblong in shape; exceedingly productive; will stand more heat than any other variety. Bushes stand high up. holding the fruit well off the ground, thereby preserving the fruit better than other sorts during rainy weather, also diminishing the number oz., 40c; lb., $\$ 5.00$.
BLACK BEAUTY.-Fruts large, handsome shape, and of a rich glossy black. It is as early as any, very productive and thornless. Our stock is true and is as good as can be grown. Pkt., 10c; oz., 53:; lb., $\$ 6.00$.

IMPROVED LARGE PURPLE THORNLESS. - For years this variety has been the standard for southern market gardeners and shippers. Our seed is pure and the plants thornless. In a properly cultivated crop. streaked or off-colored fruit is almost unknown. Plants are large, strong and vigorous, each plant producing from 5 to 8 large fruits of dark, rich purple color. Earliest large-fruited variety. A trial will make you appreciative of the superiority of this variety over many others. A Pkt., 10c; oz., 40c; lb., $\$ 5.50$.

\section{ENDIVE}

One ounce will sow 100 feet of row: 3 pounds will plant 1 acre of land In rows 3 feet apart.

CULTURE.-Seed may be sown any time during the year. When plants are well started, thin out to 10 inches apart in the row, or they may be transplanted to fresh rows. When plants have reached a good size, gather the leaves closcly together and tie loosely in an upright bunch. This bleaches the inner leaves in about ten days and adds to the crispness as a salad, as it renders the flavor mild and delicate.

BATAVIAN, or ESCAROLLE.-Forms large heads of broad, thick leaves, which can be blanched for a salad or it will make excellent cooked greens. Pkt., 5 cts.; oz., $15 \mathrm{c} ; 1 / 4$ lb., 35c; lb., $\$ 1.25$.

GREEN CURLED.-One of the hardiest and best for general use. The deep green leaves are beautifully cut and curled, easily blanched and become very crisp and tender and fine-flavored. Pkt., 5c; oz., 15c; $1 / 41 b_{2}, 35 \mathrm{c} ; 1 \mathrm{~b} ., \$ 1.50$.

m WH TE CURLED. - This beautiful variety does not need blanching to prepare it for use. The midribs being naturally of a pale golden yellow, and the finely curled leaves almost white. Pkt., 5c;02., 15c; $1 / 4 \mathrm{lb} ., 40 \mathrm{c} ; 1 \mathrm{~b} ., \$ 1.50$. 


\section{KOHLRABI}

One ounce to 100 yards of row.

A vegetable intermediate between the cabbage and turnip, which combines the flavor of both. It forms a turnip-shaped bulb above the ground, which is prepared for the table like turnios. If used when young and tender, makes a delicate and desirable vegetable. Also known as "Turnip-rooted Cabbage." Sow in rows 18 to 20 inches apart, thinning out to 8 inches.

EARLY WHITE VIENNA. Tho best variety. Bulbs about the size of an apple when ready for use. Pale whitish green color. They have a delicate cabbage
flavor. Pkt., 10c; oz., $25 \mathrm{c} ; 1 / 41 \mathrm{b.,} 90 \mathrm{c} ; 1 \mathrm{~b} ., \$ 3.00$.

\section{KALE or BORECOLE}

One ounce will produce 3,000 plants. Four pounds to plant an acre. Matures in about 50 days.

CULTURE.-Sow from the middle of March to the beginning of April in prepared beds; transplant in April and treat in the same manner as for cabbage. Of all the cabbage tribe, this is the most tender and delicate, and should be much more extensively grown than it is. The varieties are all extremely hardy, and are best

When touched by frost. CURLED SCOTCH.-Rarely exceeding 18 inches in height, but spreading out under good cultivation to 3 feet in diameter; leaves beautifully curled and bright green. Plst., 10c; 0z., 15c; 1/4 1b., 50c; lb., \$1.75.

GREEN CURLED SCOTCH. C. Cows about 2 feet high; leaves dark green. curled and wrinkled; very hardy, and is improved by a light frost. Pkt., 10c; oz.. 15c; $1 / 4$ lb., 50c; lb.. \$1.75.

SIBERIAN. Leaves curled on edges; hardy, withstanding the most rigor
winters; blue or slate-colored leaves. Pkt., 10c; oz., 15c; 1/4 lb., 50c; 1b., \$1.75.

\section{LEEK}

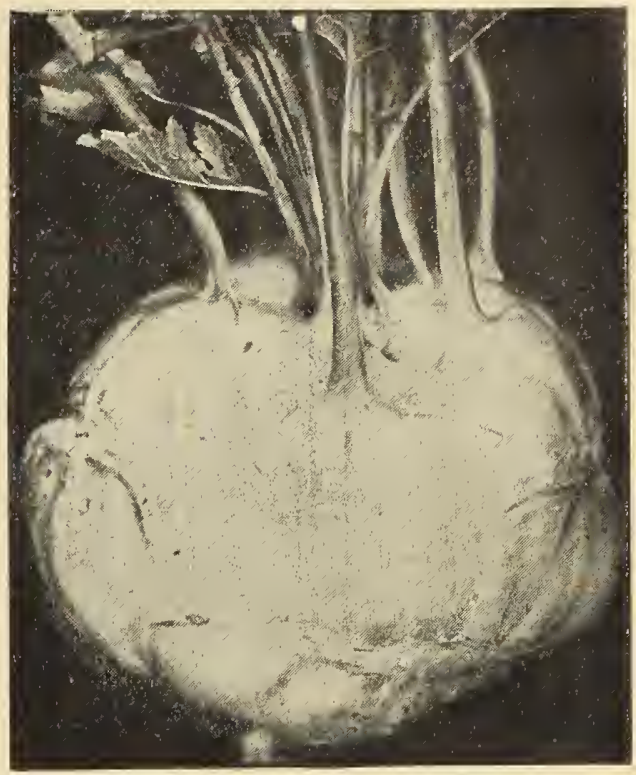

Four pounds to plant an acre.

Early White Vienna Kohirabl

Culture of Leek is about the same as onions. Sow either in early fall or spring. Sow in beds or drills, and, when 6 inches high,

transplant in rows, setting as deep as possible without coverin; center leaves. LONDON FLAG.-The oldest and best known and most largely grown variety. Pkt., 5c; oz., 25c; lb., $\$ 3.75$.

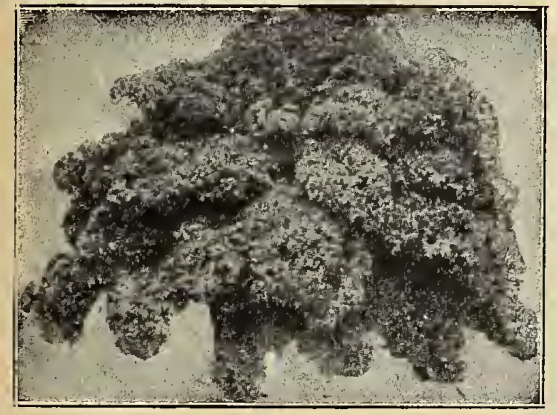

Dwarf Green Curled Scotch Kale

\section{MUSHROOM SPAWN}

CULTURE. - Mushrooms may be grown in cellars, under benches of greenhouses, or in sheds, wherever the temperature of 50 degrees can be kept up through the winter. The beds should be made from November to February, according to the time the 7 ushrooms are wanted, and it requires about two months for them to begin bearing. Secure fresh horse manure, free from straw and litter, and mix an equal bulk of loam from an old pasture with it. Keep this under cover, taking care to turn it every day to prevent heating, until the pile is large enough to make a bed the required size. Three to 4 feet wide, 8 inches deep and any length desired are the proper proportions for a bed, but these may be varied. Prepare the mixture of loam and manure, makin with the back of the spade. Leave this to with the back of the spade. Leave this to heat through for a few days, and as soon as the heat subsides to 90 degrees, make holes in the bed about a foot apart each way. and about one inch deep, into which put pieces of the spawn 2 or 3 inches in diameter; the up the holes with the compost, and at the expiration of a week or ten days the spawn will have thoroughly diffused itself through the bed. Spread a layer of fresh soil over the heap to the depth of 2 inches and cover with 3 or 4 inches of hay, straw or litter. Examine the bed often to see that it does not get dry. Take special care, however, when water is given, that it be at a temperature of about 100 degrees.

$\begin{array}{ccc}\begin{array}{c}\text { Per } \\ \text { brick }\end{array} & 10 & \begin{array}{c}100 \\ \text { bricks }\end{array} \\ \text { bricks }\end{array}$

American pure cul-
ture spawn...... $\$ 0.20 \quad \$ 1.80 \quad \$ 16.00$

\section{WATER CRESS}

CULTURE.-Sow Water Cress in the spring, along the edges of creeks or ponds. The seed can also be sown in seed hed in a of streation, and the young plants transplanted and attractive

\section{ATTENTION! \\ MARKET GARDENERS, TRUCK GROWERS, LARGE FARMERS.}

We want you to go over this Catalog carefully, make up a list of the seeds you need and the quantities of each, and send to us for special prices.

We are in close touch with you, understand your soil and climate, and our many years' experience in the state has taught us the needs of the Florida farmer, and we are in position to serve you better than any outsider.

We have one of the largest stocks of selected and tested seed to he found in the south We know that, quality considered, we can supply your wants at as reasonable prices as any other we can supply your wants at as reasonable prices as any other here to serve you and hope that you will call on us often. plant for creeks or ponds, but purifies the water. $I_{i}$ is also developing into quite a profitable industry in some sections for shipment and sale in our larger markets.

TRUE WATER CRESS.-Grows along the banks of ponds and streams, and is easily introduced: leaves are quite large and thick; a fine salad, sold in immense quantities in the large markets in spring. Pkt., 10c; oz., 40c; 1/4 lb.. $\$ 1.25$.

CRESS or PEPPER GRASS. - This is much used with lettuce, to the flavor of which its warm, pungent taste makes a very agreeable addition. The seed should be sown in drills about 16 inches apart. on very rich ground, and the plants well cultivated. Repeated
sowing is necessary to secure a succession. Pkt., 10c; oz., 15c; $1 / 4$ lb., 30c; 1 b., \$1.50.

Hogan, South Jacksonville, Florlda.

E. A. Martin Seed Co., Jacksonville, Fla. June 21st, 1919 .

. Aentlemen: Last fall my son purchased a few of the Early Suwanee Cabbage seed which you advertlse. I found thls to be the best cabbage I have ever ralsed. I usually plant two or three varieties of cabbage but this year I am only planting the Early Suwanee as it has proven to be the best cabbage I have ever planted. I sold them at $\$ 1.25$ per dozen ihe whole season through. I am right here near you and wlll deem it a pleasure to see any one
about this cabbage you have. Thls is the best cabbage I about thls ca

Yours very truly, B. F. THOMPSON 


\section{E. A. MARTIN SEED COMPANY, JACKSONVILLE, FLORIDA}

\section{Martin's Lettuce}

One ounce will sow 100 square feet, or 120 feet In drill.

Three pounds to an acre. From 40 to 50 days from sowing to matarity.

Lettuce can be sown almost every month in the year in our section. If you have hotbeds or even coldframes, you can produre fine big heads all through the winter months. In Florida it is grown as an open-ground crop through the winter months, it is grown as an open-ground crop through the winter months, and when plants are well up transplant in rows 2 feet apart. placing plants 6 inches apart in the row. L placing plants 6 inches apart in the row. bitterness, the gio vth must be rapid. If Lettuce is grown in above manner and head varieties used, you will not fail to make good heads.

BIG BOSTON.-. This beautiful splendid Lettuce has steadily gained in populari $\mathbf{i}^{+}$until now it is more extensi ely grown than all other vasie ies throughout the largo trucking sections of the South. It may be grown in the open ground for summer and fall use. or in frames under canvas. and always makes large, fine, buttery yellow heads with thoroughly blanched hearts: crisp, tender hearts: crisp, tender. White and s reet. Wo cannot recommend too highly our splendid strain of this most exrellent variety.
It gives the best of satisfaction under all possible conditions. Pkt., 5c; oz., 15c: 1/4 lb., 50c: lb., $\$ 1.50 ; 5$ lbs., $\$ 6.25$.

PRIZE HEAD EARLY.-Leaves green and red, very thin' crisp and tender. une of the very best for private use. Pkt.' 5c; oz., 15c; lb., \$1.00.

CALIFORNIA CREAM BUTTER.-Good for open-ground planting at all seasons in the South. Heads large and solid the planting at all seasons in the South. Heads large and solid. the inside blanching to a beautiful cream
The pure strain of this variety can be The pure strain of this variety can be dis'inguished by the sniall spots on
the outer leaves. Our stock is strictly the outer leaves. Our stock is strictly
high grade and of the purest strain. Pkt., 5c;0z., 20c; $1 / 4$ lb., 60c; lb., $\$ 1.75$.

HENDERSON'S NEW YORK CABBAGE.-Fine new sort, with weighing noarly four pounds: nearly weighing noarly four pounds: nearly as large as summer cabbage; one of oz.. 15c: $1 / 4$ lb.. $60 \mathrm{c}$ : lb.. \$1.75.

SIMPSON EARLY CURLED. White-seeded. A leading early sort. good for forcing or open ground; a favorite with market gurdeners. Pkt

MAY KI VG.-Handsome, light green, heading variety of medium size and excellent quality. Outdoors the heads mature exceptionally early, attaining a size suitable for use before other sorts, and often the edges of the outer leaves have a brownish tinge. The plant is very compact for so large a hoad. It is very satisfactory also for forcing under glass. Pkt. $5 \mathrm{c}$; oz.. 20c; $1 / 4$ lb.. 50c; 1b., $\$ 1.75$.

BLACK-SEEDED SIMPSON. - Very popular sort among market gardoners. Forms a large, loose head, is nearly white, curly leaves thin. exceedingly tender and of good quality. Splendid for growing under glass and early planting outside. glass and early planting outside. $\$ 1.75$.

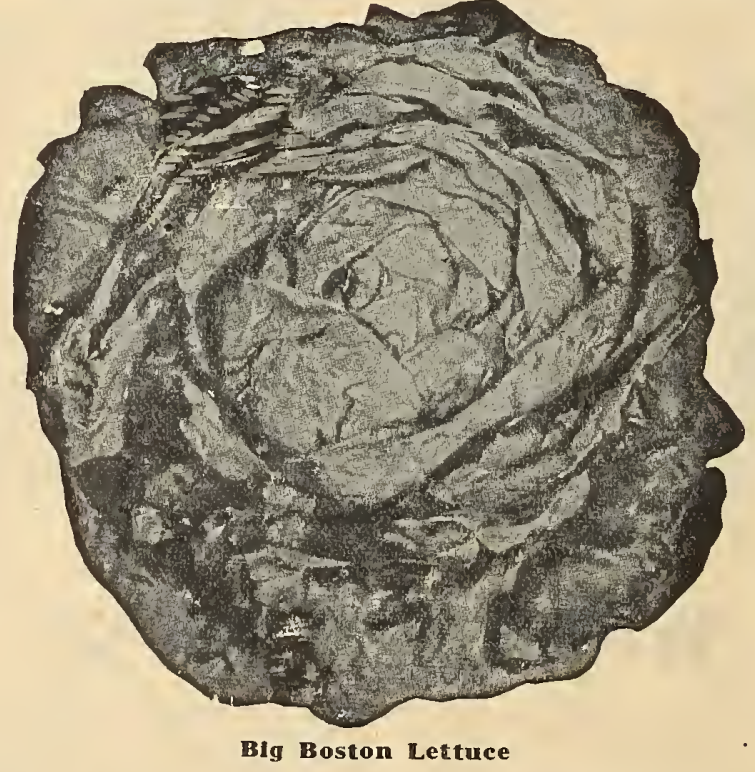

OSTRICH PRUME.-Double curled. Exceeringly ornamental. Green Very superior to any other curly sort. Very delicate in texture; well named. Pkt., 10z; oz., 15c; 1/4 lb.. 2je; lb., 90c.

\section{PARSLEY}

One ounce for 150 feet of drill. Seven pounds to plant an acre. About 65 days from sowing to cutting.

CULTURE.- Sow thickly in rows a foot apart and half an inch deep. For winter use protect in a frame or light cellar, or in pots or boves in the house. dance of finely curled leaves. Pkt.. 10c: $0 z$. $15,: 1 / 4,1 b, 49 c ; 1 b ., \$ 1.50$.

\section{PARSNIPS}

About 8 punds to plant an acre.

The value of Pars ios is not well enough known in the South. They are not only very valuable as culinary vegetables but they make the very best cattle feed exceeding enen the rarrot in value for this purpose rovequire a deeply prepared loam for their fullest development. The seed is very slow to germinate and sholld he wn parls it the sriving in rovs 18 inches apart for hand cultivation or 30 inch 's apirt for horse cultivition. 'Thin out to 6 inchr's in the row. (iul i ace J', OU.
SUGAR, Or HOLLOW CROWN. - The very best sort in existence. A large yielder of the finest quality. Pkt., 10c; oz., 15c; $1 / 41 \mathrm{~b}, 40 \mathrm{c} ; 1 \mathrm{~b} ., \$ 1.50$. 


\section{HIGH MARTIN'S HY-TEST ONIONS FULLY BRED MARTIN'S HY-TEST ONIONS TESTED}

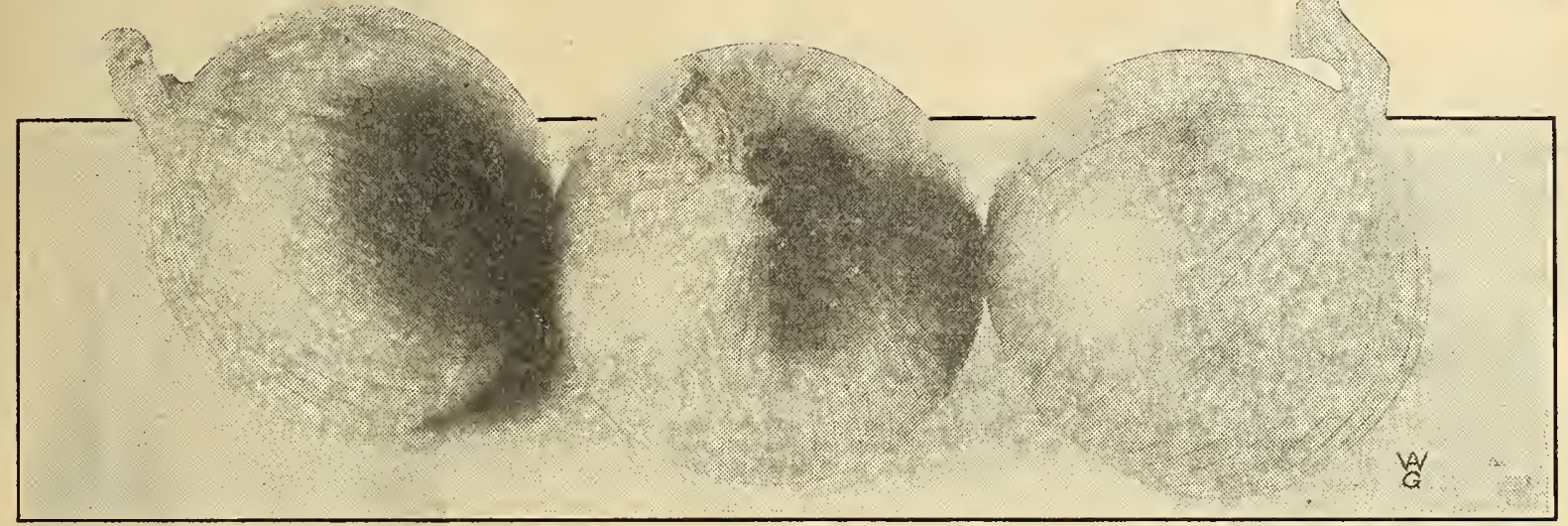

Prizetaker Onions

One oumce will plant 100 feet of drill, 5 or 6 pounds In One ounce will plant 100 feet of drill, 5 or 6 pounds in
drills for an acre. For sets from 50 to 60 pounds should be drills for an acre. For sets from 50 to 60 pounds should be
sown to the acre, according to the richness of the soll. Masown to the acre, according to the
tures about 180 days from sowing.

CULTURE.-The Onion, unlike most vegetables, succeeds well when cultivated on the same ground for successive years. Sow thinly in drills about $1 / 4$ inch deep and 1 foot apart; cover with fine soil and press down with the back of a spade or a light roller. When the young plants are strong enough, thin gradually so that they the young plants are strong enough, thin gradually so that they frand 3 or 4 inches apart. Keep the surface of the ground open and free from weeds by frequent hoeing, taking care not

too deeply, or to collect it about the growing bulbs. Bermuda. The Red Bermuda is also on for Florida is the White Bermuda. The Red Bermuda is also grown to considerable extent.
Creole is also planted to some extent; this is sometimes spoken of as the Spanish Onion, at other times the Bermuda Onion is spoken of as the Spanish Onion.

\section{Bermuda Onions} (GENUINE TENERIFFE-GROWN)

These are the Onions which southern growers are shipping every spring in enormous quantities to northern markets. They are tender and of the finest Onion flavor. Our genuine Teneriffegrown seeds are grown especially for us and imported direct, and we know there is no better stock to be had. May be sown either in the fall or early spring. Both White and Red varieties.

WHITE BERMUDA ONIONS
WHITE BERMUDA. - The standard variety for market crops for shipping. While it is known as "White Bermuda," it is really a light straw color or pale yellow. We make this explanation as many who grow it for the first time expect to find a pure white Onion. Less than sis monchs required from the time of sowing the seed to the full maturity and shipment of the crop. Pkt., 10c; oz. $35 \mathrm{c} ; 1 / 4 \mathrm{lb}$., $\$ 1.25 ; 1 \mathrm{~b} . \$ 4.00$.

RED BERMUDA. Identical with White Bermuda, except $t$ is a pale red and is the right variety where a red onion is preferred. Pkt.; 10c; Oz., 35c; $1 / 4$ lb., $\$ 125 ; \mathrm{lb} ., \$ 4.00$

Our Ceed is earliness.

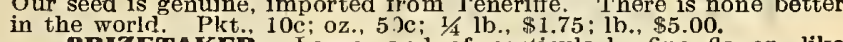
PRIZETAKER. - Large, and of particularly fine flavor, like nearly all Spanish Onions. Straw color; the flesh pure white, sweet, nearly all Spanish Onions. Straw color, the flesh pure white, sweet, mild and tender. Ripens up fine and hard, and makes a very
tractive Onion. Pkt. 10c: oz., 3.5c; 1/4 lb., \$1.0); lb. $\$ 3.75$.

\section{Red Creole Onion}

Greatest of all red Oaions. Best keeper, best producer, both in yield and money. The skin is brownish red, fiesh very solid and fine grained and rather strong flavored. Extremely productive and the besu shipper and keeper of all sor us. Without doubt, the greatest Onion for the southern Grower. iratures a little later than the Bermuda Sorts. but does not rot as easily.

Largest and best Onion under cultivation. For home garden use it is unexcelled. They can be retained after harvesting a full year without rotting. Pkt., $10 \mathrm{c} ; 0 z ., 35 \mathrm{c} ; 1 / 4 \mathrm{lb} ., \$ 1.25 ; 1 \mathrm{~b} ., \$ 4.00$.

\section{Onion Sets $\begin{gathered}\text { Measured } \\ \text { Bushell) }\end{gathered}$}

Ten to twelve bushels to the acre, according to size. Prices subject to market change.

Add 10 cents per guart if wanted by mall.

CULTURE 10 cents per quart if wanted by man. about $1 / 2$ CUL TUR.-Plant the sets 4 inches apart, in rows about sets entirely. Fall planting of Onions is succeeding very well in the south, and should be more generally practiced.

WHITE SILVERSKIN.-Plant from August to and through March. This is a uniformly early, round, tender and very handsome variety, with an opaque, white skin. Qt., 35c; pk. $\$ 1.50$; bu., $\$ 5.00$.

YELLOW DANVERS.- Mardiest of all the ordinary varieties of Onion Sets. While not the earliest, they are a good all-around, very productive variety. Write for closest market prices on larger quantities. Qt., $35 \mathrm{c}$; pk., \$1.50; bu., \$5.00.

WHITE MULTIPLIER.- Differs from the Yellow Potato Onion in color, being pure white, and does not make so large Onions. but is a better keeper than the yellow.

WHITE BERMUDA ONION SETS.-Qt., 35c; pk., $\$ 1.50$; bu., $\$ 5.00$.

NOTE. - We ship Onion Sets, measured bushel, whlle most seed houses shlp and quote 32 pounds for a bushel. 32 pounds will not measure a bushel and is only about three pecks. These facts should be thought of when ordering.

MARTIN'S HY-TEST SEEDS are tested in our seed testers and by trial on our farm. You can't go wrong on our seeds, they are DOUBLE-TESTED. 


\section{MARTIN'S OKRA}

One ounce will plant 100 hlls. Twenty pounds to plant an acre. About 60 days Cultivated for its green seed-pods, which are used in sou.

paragus. Hights served like asapples and then used for soup at any time.

CULTURE.--Sow secd thinly in dry, warm soil, in shallow drills, 2 feet apart. After plants are up. thin to 9 inches apart; hoe frequently, and draw a little earth to the stems as they grow. Gather when quite green and about $1 \frac{1}{2}$ inches long.

WHITE VELVET. - Bears round, white, smooth pods, of extra large size, in great abun-

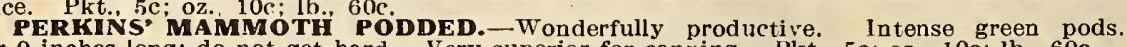
8 or 9 inches long: do not get hard Very superior for canning. Pkt.. 5c: oz., 10c: lb., 60c. thick and fleshy: early and prolific. Pkt., 5c: oz., 10c: lb., 60c

LONG GREEN.- Pods long, green, ribbed; heavy bearer. Plst., 5c; oz., 10c; lb., 60c.

\section{Martin's Favorite Okra}

Sold out on Martin's Favorlte Okra last season, long before the demand was supplied. It has given excellent results far beyond our expectations-we have recelved numbers of testimonlals. All the truckers and home gardeners also who have trled thls varlety are well pleased.

$A$ new and distinct Dwarf Green Variety. This combines the good points of all the Green varieties, and grown for the home, table or market is superior to any other. The originat or predicts that this will. within a few years. supersede all other Green Okra. just as the White a half feet, produces long slender green pods (10 to 12 inches) comparativcly free from ridges and the most prolific the originator has ever seen, easily produces 20 per cent more caskets of uniform size pods than any other.

We assure you that you will make no mistake in planting Martin's Favorite Okra, either for home or market.

We anticipate a big demand for this variety and the supply is limited, and our supply may be exhausted before all of our customers orders are filled. However, we trust that every grower
will be able to try this new variety. Price per lb., 85c; oz., 15c; in 5-1b. lots., 85c lb.; in 10-1b. lots, $75 \mathrm{c}$ per $1 \mathrm{~b}$.

\section{PEPPERS}

One onnce to plant 100 yards of row. Is edible in 90 to 120 days.

Peppers are very popular in all sections of the South. They are largcly used in salads, etc. The thick-fieshed sorts are very fine sliced. Peppers should be sown early in boxes or hotbeds and transilanted into a boxes or hotbeds and transilanted into a 2 loamy well-fertilized situation in rows about 2 feet apart, and 18 inches to 2 feet in the row. Cultivate often and thoroughly, continuing until frost, and you will be rewarded
with a continuous crop as long as cultivation with a continuous crop as long as cultivation
is kept up. The seed we offer is of the very best strains, carefully tested.

RUBY KING.- Enormous variety, $41 / 2$ to 6 inches long and ahout 3 inches thick. The fiesh is very thick, tender, mild and to the taste. Fine sort for stuffing cellent dish of salad. Foliage is very distinct cellent dish of salad. Foliage is very distinct, oz., 50c; $1 / 4$ lb., $\$ 1.75$; lb., $\$ 6.00$.

MAMMOTH BELL, or BULL NOSE. - Most popular sweet varicty. Very mild in flavor and flesh very thick. It is a very fine variety for pickling. Pkt., 10c; oz., $50 \mathrm{c}$ : $1 / 4$ lb., $\$ 1.75 ; \mathrm{lb} ., \$ 6.00$.

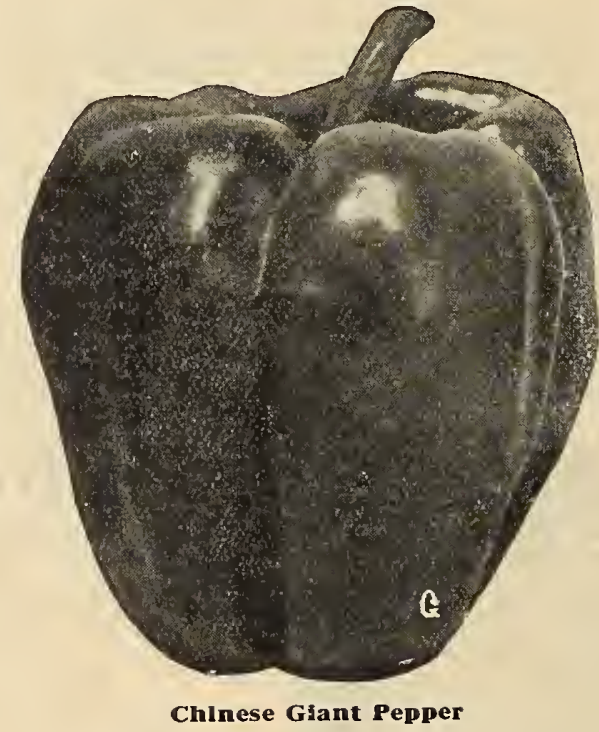

PIMENTO PEPPER

This Pepper is of the "Pimento" type and has been brought
to a degree of perfection which we have not found in any

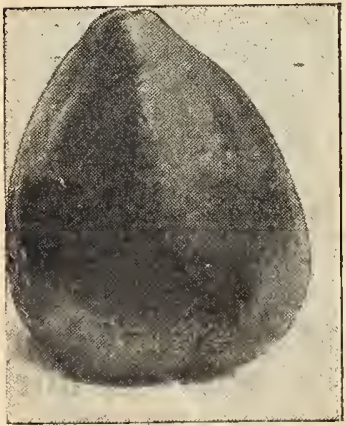

Plmento Pepper. other strain or variety that we bave ever seen or grown. Fine for the home garden. both green and ripe. So smooth and uniform in shape that the skins can be easily slipped off after burning over a hot fire a fow seconds or by boiling a few minutes in hot water. It can also be pared like an apple by using a sharp knife. The hull or types, and yields about a half more edible product to the same measurement.

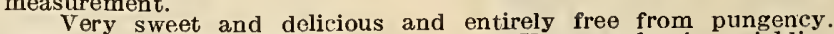
When ripe it is a beautiful scarlet red. Very productive, yielding heavy crops until cut off by frosts. In consequence of the many superior and valuable qualities of this Pepper it is much sought and grown and valuable qualilies of this Pepper it is much sought and grown by canners for pimento pickles
$1 / 2$ oz.. 25c; 07.. 45c: $1 / 1$ lh.. $\left.9^{n} \mathrm{c}: 1 \mathrm{l}\right) . .3 .50$.

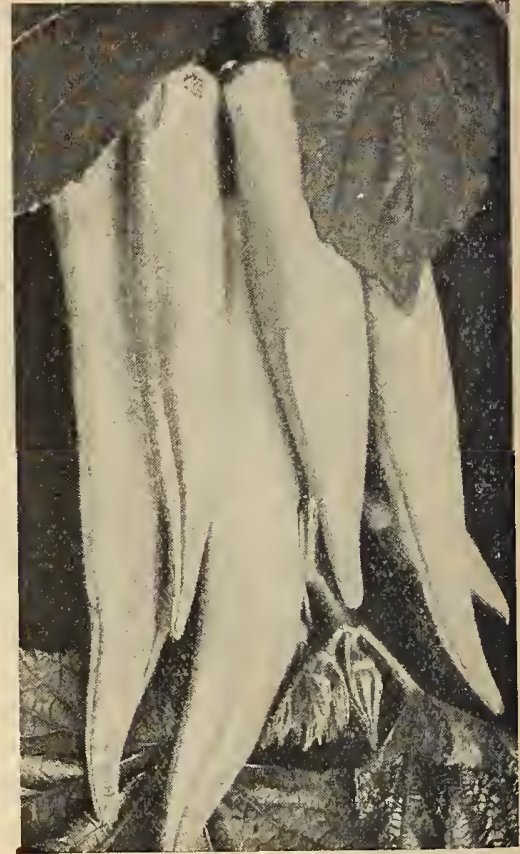

Martin's Favorlte Okra.

SWE E T SPANISH MONSTROUS.-Laigest sweet Pepper Plants are of extra strong, vigolous growth, branching freely and very prolific. Fruits much larger than Ruby King and Large Bell, almost square in shape. Flesh very thick. Its flavor is rery mild and frec from flerv taste. Pkt., 10c; oz., 40c; $1 / 4 \mathrm{lb}$. $\$ 1.50$; 1b., \$5.75.

RUBY GIANT. $\rightarrow$ (New) Largest of all Red. Pkt. 10c: oz. $50 c ; 1 / 4$ lb., \$1.75; lb., \$6.50.

CHINESE GIANT. - An enormous sort, sometimes measuring six inches in dianetcr. Very handsome, mild and sincrior qualit $v$ for stilffing. Plants are vigor us and very prolific, lat mituring. We strondiy recommend this, either for home use or $\$ 1.75 ;$ ib., $\$ 6.50$.

CAYENNE.-A long. slim pod, rather pointed, and when ripe, a bright red color. Extremely strong and pungent. Pkt.. 10c; oz., 40c $1 / 41 \mathrm{~b} ., \$ 1.50 ; 1 \mathrm{~b}$., $\$ 5.50$.

RED CHERRY.-Fruit small and cherry-shaped: largely used for pickles, as they are very hot. Plkt., $10 \mathrm{c}$ : oz., 40c; $1 / 4$ lb., \$1.50; lb., \$5 50 .

NEAPOTITAN. - Valiable for our southern shippers and mirket gard ' $n$ ers from thi fict thut it is $\mathbf{1 0}$ days to two weeks earlier than any other large mid red Pepper. Plants are very strong, very stocky, and the peppers are borne erect, the plants complctely laden with large. handsome fruits, bearing continuously until frost. The skin and flesh are bright red, thick meat, sweet and mild as an apple. Carries well and keeps in prime condition a long time. Pkt., 10c; oz., 60c; $1 / 4$ lb., $\$ 2.25 ; 1 b$. $\$ 8.00$.

E. A. Martin Seed Co., Jacksonville, Fla.: Gentlemen-Please send me at once by express C. o. D. (12,000) twelve thousand Early Jersey Wakefield Cabbage Plants, 200 Improved Large

Purple Eggplants and 200 Henderson's Early Snowball Caulifower. were fine plants and have done extra well ln the field. Hope this order wlil do as well. Yours truly. 


\section{MARTIN'S ENGLISH or GARDEN PEAS}

CULTURE.-Two or three bushels are required to the acre. The smooth varieties are the hardiest and should be planted first. The seed is usually sown thickly in double rows, and these double rows, constituting one row, should be about $31 / 2$ to 4 feet a part. Cover seed 2 or 3 inches, and, if too thic:k, thin to about $1 \frac{1}{2}$ to 2 inches. Cultivate often, especially in dry weather. A thick stand is desirable. It is not necessary to proside supports for the dwarf sorts. Peas grow fairly well on poor soils, but a little fertilizer will greatly increase the yield. Well-rotted stable manure in the drill is spelendid, but fresh manure should be avoided unless it is broadcasted.

FIRST AND BEST.-Splendid strain of first-early Peas. May not be, in certain respects, the equal of some of the newer specialties. yet: for general purpose planting. where a tested variety is wanted, this will give full satisfaction. Pt., 35c; qt., 60c; pk., $\$ 4.00$; a tested variet

BLISS, EVERBEARING.-New second-early variety, about ten days later than the American Wonder, bearing large, well-filled pods, containing about seven or eight Peas each. The vine is of dwarf habit, growing from 15 to 20 inches in height. Pt., 30c; qt. $50 \mathrm{c} ;$ pk.j $\$ 3.25 ;$ bu. $\$ 14.50$

CLAUDIT--Resembles the Alaska, except that the pod is broader and a trifle longer. 40c: qt.; 75c; pk., \$4.50: bu.., \$17.00

ALDERMAN. - Very large-podded Pea, robust and vigorous, produring pods of the largest size. The pods are even larger and longer than the average large-podded sorts, and are well filled with large Peas of most excellent flavor. Vines are strong and branching, bearing rich, deep green, straight, handsome pods, pointed at the end. Belongs to the tallgrowing main-crop class of Peas. Vines are from $31 / 2$ to 4 feet in height. A point of superiority which must not be overlooked is the unusual fiavor and quality of the Peas. As is true of most wrinkled varieties they are delicious, but the Alderman is of a quality surpassing many of the others. Be sure to include Alderman Peas in your order. Pt., 40c; qt., 75c; pk., \$4.25; bu., \$16.00.

TALL TELEPHONE.-Pods are very large, filled with immense Peas of a first-class quality; on $\theta$ of the finest yet introduced. Height, $41 / 2$ feet. Pt., 40c; qt., $75 \mathrm{c} ; \mathrm{pk} ., \$ 4.25$; bu., $\$ 16.00$.

DWARF TELEPHONE.- (Carter's Daisy).-Excellent new yariety; large, well-filled pods: Peas of fine fiavor. Height, $11 / 2$ feet. Pt. $40 \mathrm{c}$ : qt. $75 \mathrm{c}$. pk 84.25 bu 16.00.

CHAM PION OF ENGLAND. $\frac{2}{2}$ One of the best late Peas grown. of delicious flavor and a very profuse bearer. Desirable for home use, and especially recommended for market gardeners, and for extensive planting for the home market. Height, 5 fcet. Pt., $30 \mathrm{c}$; $\mathrm{qt}$. $50 \mathrm{c}$; pk., $\$ 3.75$; bu., $\$ 14.50$.

GRADUS, or PROSPERITY. The most popular, large-podded, wrinkled sort Matures just after the extra-early varieties and produces a good crop of pods 4 inches long, providing it is planted on lisht, warm rich soil, but very disappuinting under adHerse conditions. The quality is excelient. bu., $\$ 17.00$.

DWARF CHAMPION, RICE'S IMPROVED.--Very productive; Peas large fine fiavor. Height, 2 fcet. Pt., $35 \mathrm{c}$; qt., $60 \mathrm{c}$ pk., \$4.00; bu., \$15.00.

PHILADELPHIA, EXTRA-EARLY. One of the best first-early sorts. Very productive, and free from runners. Grows from 2 to 3 feet high, and will mature for table about forty-five days from germination. frequently in less time. A good Pea for market gardeners. Pt., 35c; qt., 60c; pk. $\$ 4.00$; bu.. $\$ 15.00$

THOMAS LAXTON.-A heavy cropper, bearing uniform, long, straight, square ended, dark green pods, containing seven to eight large, rich-flavored Peas: a deep green color adding to their attractiveness when served. Almost as early as the extraearly smooth Peas. 3 feet high. Pt., $45 \mathrm{c}$; qt., $80 \mathrm{c}$; pk., $\$ 4.50$; bu., $\$ 17.00$.

A LASKA.-Our strain of this variety is the very best. This Pea is increasing in popularity every year. Especially valuable beautiful green of its pods and Peas, which it retains longer than any other varietics, making it particularly valuable for shipping making it particularly valuable for shipping purposes. Sperially desirable for canners.
Pt., 45c; qt., 80c; pk., $\$ 4.50$; bu., $\$ 17.00$.

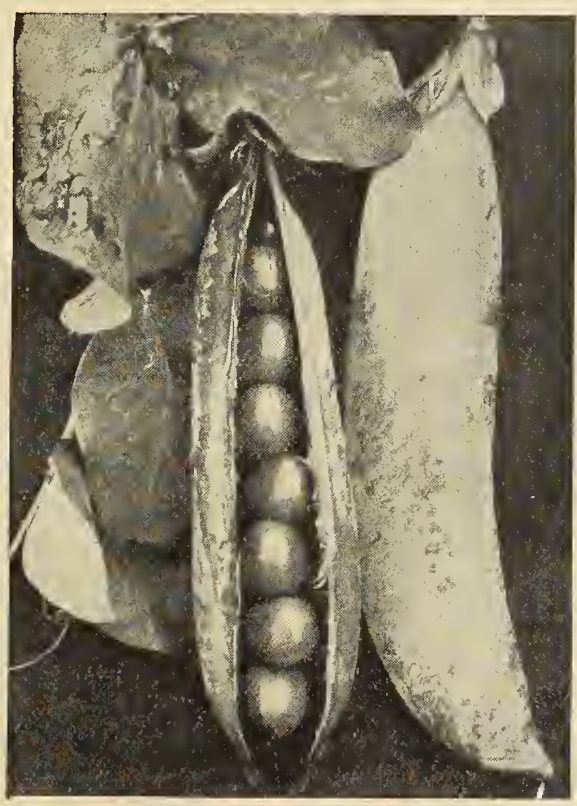

Garden Peas

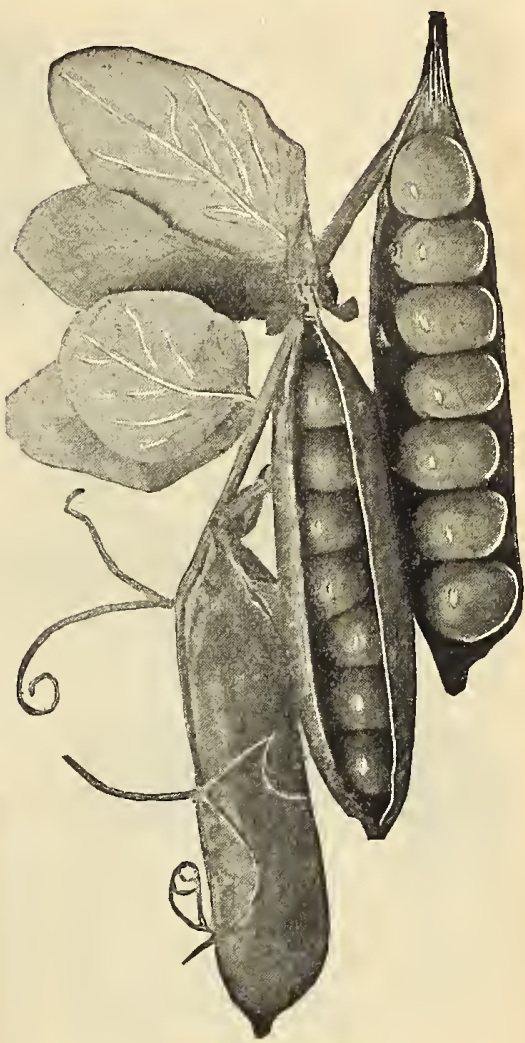

Alderman Peas

\section{MARTIN'S} POTATOES

In drills 3 feet apart, 12 to 14 bushels to the acre; one peck will plant about 125 hills.

\section{VARIETIES}

The best varieties for planting in the South, and especially in Florida, are the early and extra-early varieties. such as the Bliss Red Triumph, Irlsh Cobbler, Improved Rose Number 4. These are the extra-early and the best for growing in Florlda for the first crop. Second earliest can ln some sections be grown with proflt, but not generally throughout the state for commercial purposes.

The time of planting potatoes in Florida depends upon the section of the state. In the far southern portions they can be planted as early as Derember, growing later up to $\mathrm{N}^{\top}$ arch as we go farther north, indicating the change necessary to conform to the seasons and location, the difference being about ten to twelve days for each 100 miles.

ROSE NO. 4.- A favorite with Florida truckers; has given universal satisfaction for several seasons.

\section{PRICES ON POTATOES}

Rose No. 4

$1 / 4$ bu. $\quad$ Bu.
$.90 \quad \$ 3.50$

Bag.
$\$ 6.50$

\section{SEED POTATOES FOR FALL PLANTING}

Spauiding's No. 4 Rose. Write for prices.

For fall planting the small native grown potatoes are pianted whole and not cut as the northern potatoes are for spring.

We sell a great quantity of seed potatoes each season and our seeds are noted for the high quaify and being the best selected stock if want ain quantities of 5 bags or more, it wiil pay you to write us for special prices.

Potatoes weigh 60 pounds per bushel. Add postage if smail quantity is wanted by mall. 


\section{NEW MARTIN'S HYYTESTT RADISHES FRESH CROP MARTIN'S HY-TEST RADISHES TESTED}

\begin{abstract}
Two ounces wlll sow 100 feet of drill; 8 to 10 pounds to plant an acre. Matures for table In 20 to 30 days.

CULTURE.-Sow in the spring as soon as the ground can be mellow soil. 'The early, smali varieties can be sown broadcast among other crops. such as beets. atong other crops. such as beets. peas, etc. Sow every ten days for Gulf Coast, they can be sown all through the winter.
\end{abstract}

Prices are by mall, postpald.

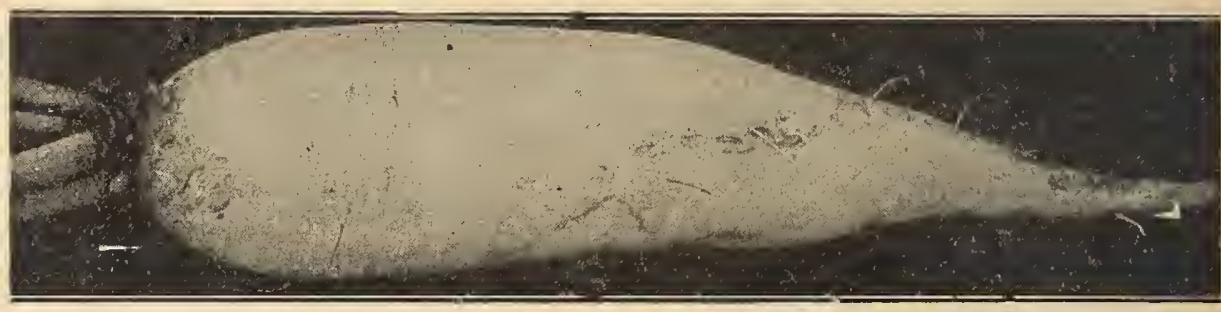

White Hercie Kadist

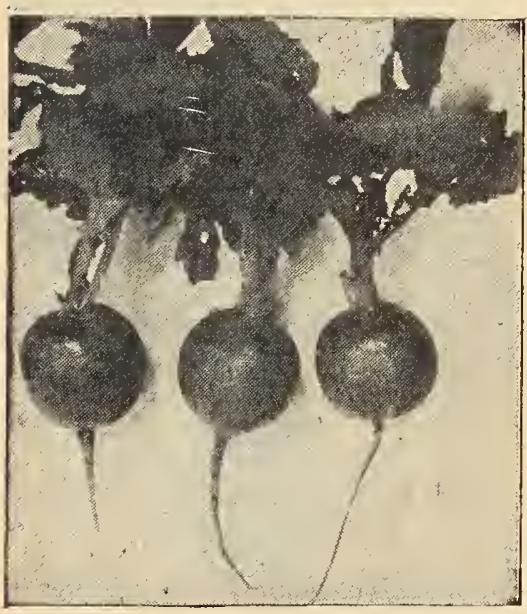

Round Black Spanish Radish

EARL Y LONG SCARLET SHOR T-TOP.-One of the best Radishes on the list; very early, attaining a large size; of very best flavor, and will remain in eating condition longer
without getting pithy than any other sort. Our strain of this sort is very fine. Pkt., 10c; OZ, $15 \mathrm{c}, 1 / 4 \mathrm{lb}$, 35c: $1 \mathrm{~b}$. \$1.25. sorts on the market. An early planting sort; very hardy; quick growing. Turnin-shaped. bright scarlet with white tip; one of the most salable sorts. Flesh firm and crisp; small tops, Pkt., 10c; oz., $15 ; 1 / 41 \mathrm{~b} ., 35 \% ; 1 \mathrm{~b}, \quad \$ 1.25$

F R E fine forcing Radish, maturing in twenty days from skin $b$ i rht scarlet, but tipped at the end with pure white. Pkt., 10c; oz., 153: 1/4 lb., 30c; lb., 1.15

WHI TE ICICLE.-Produces beautíful, long, white roots, extremely early, hence decidedly popular for forcing and a solendid sort for light, deep soil for out-of-doors. In twenty-flve days after sowing this radish is ready for pulling. Pkt., 10c; oz., 15c; $1 / 41 \mathrm{~b}$. $40 \mathrm{c}$; $1 \mathrm{~b}$. $\$ 150$.

LONG BLACK SPANISH.-One of the largest, latest, as well as the hardiest of $\mathrm{Rad-}$ ishes. Roots of medium size, oblong, black, and flesh is of firm texture. Pkt., 10c; oz, 15c; $1 \mathrm{~b}, 35 \mathrm{c} ; 1 \mathrm{~b}, \$ 1.25$. cellent: one of the best for fall and ROUND BLACK SPANISH. - Roots round, sometimes top-shaped, three or four inches in diameter; skin black; flesh white. Fine for winter use; as the roots keep a long time. Pkt., 10c: oz., 15: $1 / 4$ lb., 40c: lb $\$ 1.50$

EARLY RED, or SCARLET TURNIP.-Dark crimson color, with white flesh. Splendid for general early use. does not get pithy as soon as most of the early sorts. Pkt., $10 \mathrm{c} ; \mathrm{oz} .15 ; 1 / 4 \mathrm{~b}, 30 \mathrm{c} ; 1 \mathrm{~b}, \$ 1.00$.

rerer forcing or open ground. Tops 6 to 7 inches long. The flesh is very tender, crisp and delicious. A handsome variety bright red in color, and remains in good condition for several days. Pkt., $10 \mathrm{c} ; \mathrm{oz} ., 15 \mathrm{c} ; 1 / 4 \mathrm{lb}$., 30c: 1 . 1.00 . continues until nearly six inches long making it almost an all-season Radish. Flcsh flrm, continues until nearly six inches long, making it almost an all-s
solid and pure white. Pkt., $10 \mathrm{c} ; \mathrm{oz}, 15 \mathrm{c} ; 1 / \mathrm{lb} . .35 \mathrm{c} ; \mathrm{lb} ., \$ 1.25$.

\section{MARTIN'S}

Two ounces will sow 100 feet of drill; 25 pounds one acre. Matures for table use in about 40 days.

One of the most desirable winter and spring greens, and is better liked and usually sells at much higher prices than kale or turnip salad. Is largely grown for shipping.

CULTURE.-For early summer use, sow early in spring in a good, well-fertilized soil, in drills 1 inch deep, $1 \frac{1}{2}$ to 2 feet between the rows. For winter and spring use, sow in October. Requires but little cultivation. Best developed and most tender and succulent when grown in rich soil.

\section{MARTIN'S SQUASH}

One ounce of early varletles wlll plant 50 hlls; one ounce of marrow sorts, 25 hills. Early varieties mature for table use in about 40 days.

CULTURE. The plants are very tender and sensitive to cold, and planting must be delayed until settled warm weather. The general principles of culture are the same as those given for cucumbers and melons. but the plants are less particular as to soil. The summer varieties should be planted 4 feet apart each way and the winter sorts, 8 feet. Three plants are sufficient to a hill. Care for winter use, as the slightest injury will increase the liability to decas

GIANT SUMMER CROOKNECK.-Largest and one of the earliest summer varieties: fruits often two feet long, very warty and

deop orange ln color. Pkt.. 10c; oz., 25c; 1b.. \$2.00. Patty Pan Squash. Earliest. very productive; light cream-color. Popular for northern shipments for both fall and spring crops. Popular for northern shipments for both fall and spring crops.
Pkt.. 10c: oz..20c: $1 / 4 \mathrm{~b} 40 \mathrm{c}$ : $1 \mathrm{~b}$. $\$ 1.25$. MAMMOTH WHITE BUSH.- Tmproved form of the Early White Bush or Patty Pan. Is early. uniform in growth, and very prolific. Has beautlful, clear white skin and is from 8 to 12 inches in diameter. Tender and of good flavor, Fine quality and size for home gardens and nearby markets. Pkt., 10c; oz., 25c; $1 / 41 \mathrm{~b} ., 40 \mathrm{c}$

YELLOW SUMMER CROOKNECK.-Favorite in both

\section{SPINACH}

BLOOMSDALE SAVOY-LEAVED.-Heavy cropper, of fine quality and very hardy; succulent leaves curled and crinkled like a Savoy cabbage; hardiest and most productive sort. Pkt., 10c; oz., 15c: $1 / 4$ lb., $25 \mathrm{c}$; $1 \mathrm{~b} ., 75 \mathrm{c}$.

NEW ZEALAND.-Entirely different from the true Spanish in type in that it thrives during the hot weather in any soil, rich or poor. The tender shoots are of good quality and may be cut throughout the summer. Plant three or four seeds in a hill 2 feet apart each way. Pkt., 10c; oz., 15c; $1 / 4$ lb., 35c; 1b., \$1.25.

home and market gardens. Fruits rather small, of bright orange color Rich and buttery. Pkt.. 10c; oz., $20 \mathrm{c} ; 1 / 4 \mathrm{lb} ., 50 \mathrm{c}$, $1 \mathrm{~b} ., \$ 1.75$. $\$$. form good quality of its fine-grained and nutty-flavored flesh, and its good keeping qualities. Pkt., $10 \mathrm{c}$; oz., $25 \mathrm{c}$; 1/4 lb., $50 \mathrm{c}$; lb.. $\$ 1.50$. BOSTON MARROW.-Fall and winter variety: large oval;
skin thin: when ripe, bright orange, with a netting of light cream color; flesh rich salmon-yellow. Pkt.. 10c; oz., 25c; 1/4 1b., 50c; lb., $\$ 1.50$. WOOD'S PROLIFIC.-A fine Squash of the Narrow type; round and thick; deep orange, with a small seed cavity. Quality excellent, productive and keeps well. Pkt., 10c; oz., 20c; $1 / 41 \mathrm{~b} ., 50 \mathrm{c}$; lb., \$1,75

ITALIIN VEGETABLE MARROW. $\rightarrow$ A summer variety in bush habit; fruits oblong, about 12 inches in length and 5 inches in diameter: color dark green, marbled with yellow and dark green stripes. Pkt.. 10r: 07.. 25?: 1b.. \$2.00.

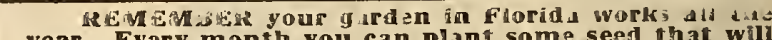
year. Every month you can plani some seed that wil keep fresh vegetables for your table every day in the year. Are you preparing to do vour part to help keep down the High Cost of LIving?

Prepare now to heat these tiogh prices, and the only way to do this is to plant a garden and increase your fnTade ernds.
} 
One ounce wlll produce 1,500 plants. For table use, 90 to 120 days, according to varlety.

CULTURE.-Tomatoes do best on light, warm, not overrich suil, and success depends upon securing a rapid, vigorous and unchecked growth during the early part of the season. Sow in hotbeds from six to eight weeks before they can be set out of doors, which is when danger from frost is past. Transplant carefully and cultivate well as.long as the ines will permit.

JOHN BAER TOMATO. The earliest Tomato on earth. our seed came from a source that we know to be reliable and was Our seed came from a source that we know to be rellable and was grown especially for us. This tomato has a bright red color and produces large, beautiful soid shipping Tumatoes, earlier than any other Tumato that can be planted. It will produce the most perfect Tumato ever grown. Will produce an enormous crop, seedless, solid and meaty: fruit weighs $61 / 2$ ounres. Being such a tremendous yielder, a bushel of "Sohn Haer" Tumatoes can be gathered in one-third the time of any other tomato. Pkg., 10c;

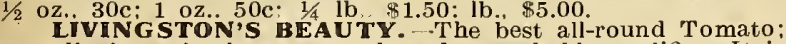
exceedingly early, large. smooth and remarkably proliqc. It is grown more largely by tru-kers and market gardeners than any other sort. The variety is of glossy crimson. With a slisht tinge of purple: skin tough, good keeper and shipper. Pkt., 10c; oz., $35 \mathrm{c} ; 1 / 4$ lb., $\$ 1.00,1 \mathrm{~b}, \$ 3.25$

35c; $1 / 4$ Ib. $\$ 1.00,1 b$ STONE. Resembles the well-known Stone in color. shape, and time of ripening; the habit of growth like the Dwarf Champion. Ripens evenly, very solid, and of excellent quality. The fruit is large, of dark brick-color, solid, fleshy and is not Tubject to rot like some varieties, nor does it over have a green subject to rot like some varieties, nor does it ever have a green
core. We can especially recommend it for a late crop. Pkt., 10c, core. We can especially recomme
oz., $25 \mathrm{c}: 1 / 4$ lb., $90 \mathrm{c}$, Ib.. $\$ 3.00$

EARLIANA. Has easily gained the reputation of being the best first-early Tomato. The plants are quite hardy, with rather slender branches and moderate growth. well set with fruits nearly all of which ripen extremely early in the season. The Tumatoes are bright red and grow close together in clusters; all of medium size. a eraging $2 \frac{1}{4}$ inches in diameter. They are smooth and solid quite thisk through and free from rough ribs or cracks. The flesh is a deep red, with solid center and small cells: slightly acid flavor. Pkt., 5c, oz., 35c; $1 / 4$ lb., $\$ 1.00$; lb., $\$ 3.50$

DWARF CHAMPION (Purplish Pink)--Sometimes called the Tree Tomato Especially desirable for small gardens, called the Tree Tomato. Esperially desirable for small gardens, as they may be grown as close as three feet. The vines are and attractive, firm solid, with thick flesh and meaty center. and attractive. firm. Solid, with thick fesh and meaty center. Bears in clusters of 3 to 5 good-sized fruits and continues

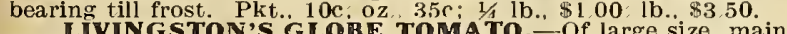
tained throughout the season. always smooth. firm-fleshed, and has very few seeds especially in the early frutits. Ripens evenly through and through Fine glossy rose in color. tinged with purple. Very attractive, Bears fruit in clusters of from three to seven fruits. Especially adapted for slicing, as the flavor is very

PEAR-SHAPED YELLOW.-Fruit pear-shaped, deep yellow color. Used mostly for preserves. Pkt., $10 \mathrm{c}$; oz., 50c; $1 / 4 \mathrm{lb} ., \$ 1.50$; lb., $\$ 5.00$.

MARTIN'S REDFIELD BEAUTY.-Cannot be beaten as an all-round variety. Second early, vigorous grower, fruits crimson an all-round variety. Second early, vigorous grower, fruits crimson shipper, the skin does not break easily. If you plant artin's Redfield Beauty for either market or home use you are planting the best. field Beauty for either market or home use y

Pkt., 10c: Oz., 35c: 1/4 lb., \$1.00, lb., \$3 50. The vines are igorous, producing a very large stalk and an unusually thick stem. which is accounted for in the great size and weight of the fruit. One of the best-flavored sorts grown, almost solid, and contains scarcely any seed. The fruit, when ripe, is cardinal-red.

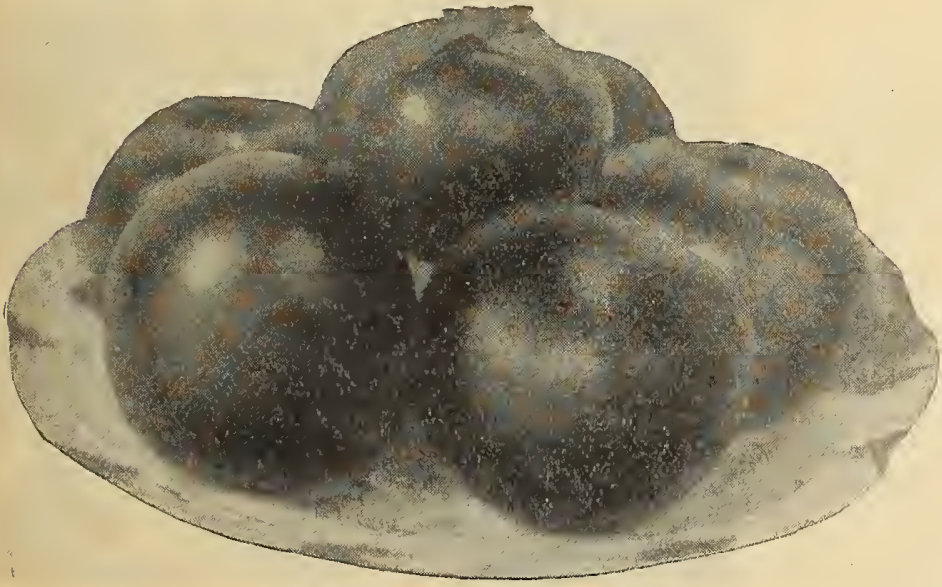

Dwarf Champion_Tomatoes

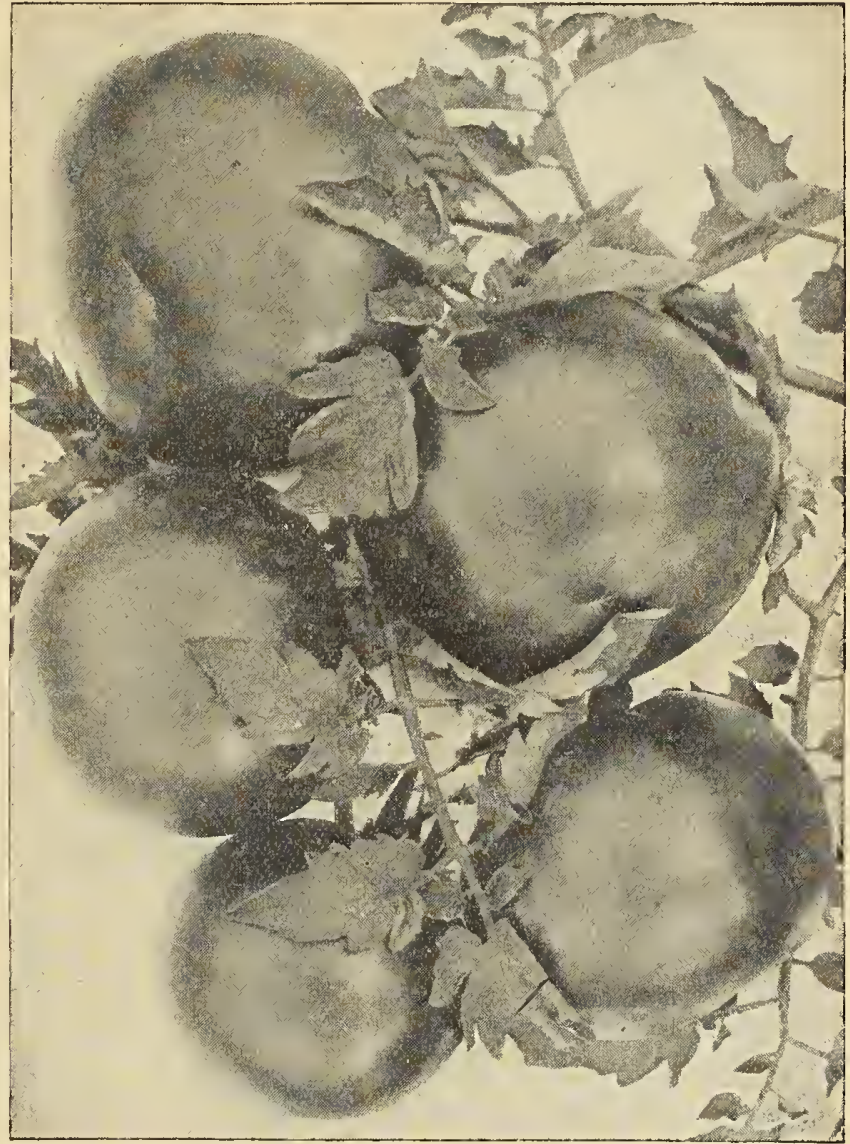

Joun baer romatoes

and, on account of its compact structure, will keep longer than any other sort. Pkt., 10c; $1 / 2$ oz., 20c; oz.. 40c; $1 / 4$ lb.. $\$ 1.50$ : lb.. $\$ 5.00$.

DUKE OF YORK. - Round, rich scarlet, large size; flesh firm and of fine flavor: blight proof. The Duke of York is the only reliable blight-proof variety Splendid shipper and makes a fine market blight-proof variety Splendid shipper and makes a fine market
appearance. Fruits form in clusters of 5 to 10 and are above the avpearance. Fruits form in clusters of 5 to 10 and are above the average size; a strong, healthy grower; big cropper, and stays in
bearing a long time. Pkt., 10c; oz.. 35c; 1/4 lb., $\$ 1.25 ; 1 b . . \$ 4.50$.

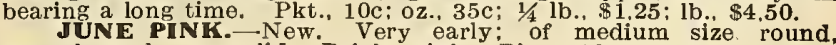
smooth, and very solid. Bright pink. Pkt., $10 \mathrm{c} ; 0 \mathrm{oz} ., 35 \mathrm{c} ; 1 / 4 \mathrm{lb}$., $\$ 1.25 ; \mathrm{lb} ., \$ 4.00$.

All prices of Tomatoes are by mall, postpald.

\section{You Cannot Afford}

under present conditions to buy seeds from sources where you are not sure what sort of seeds you are getting. You must plant the best seeds.

\section{PLANT MARTIN'S HY-TEST SEEDS}

St. Augustlne, Fla., Aug. 20, 1918.

Dear Sirs:

Havling seen such wonderful flowers In town grown from your seed, I am wonderling if you issue a catalog? If so, I would be grateful if you would semd me one. 


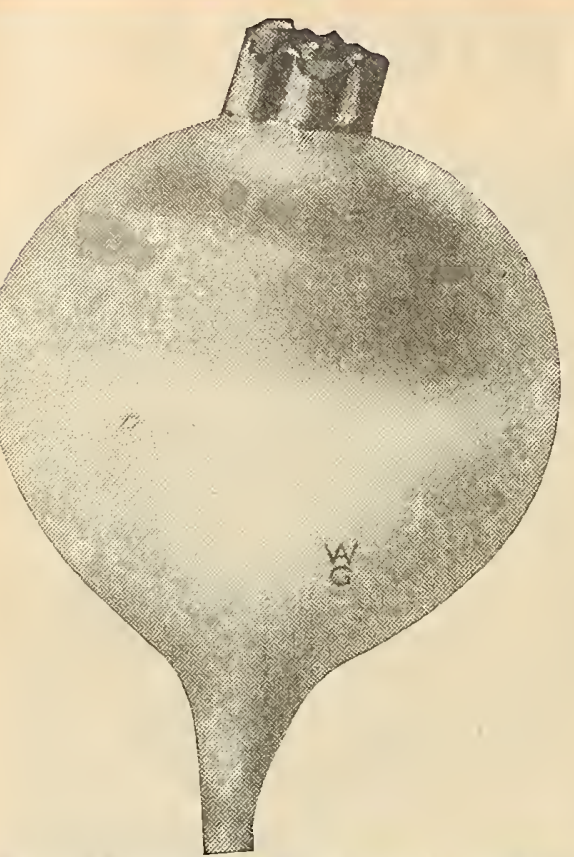

Red or Purple Top Strap-Leaved Turnlp

\section{MARTIN'S TURNIPS}

Turnips can be planted in Fiorida almost the year round. Quantity prices on Turnlps.

From 3 to 4 pounds to an acre. Matures for table use In from 55 to 85 days, according to variety.

CULTURE.- Plant for succession from September to April in drills 14 inches apart and thin out plants to 6 inches. Turnips thrive best in a highly enriched, sandy gravelly or light loamy soil. Spring sowings should be put in early so that they wil attain a good size before hot weather; otherwise they will become tough and bitter.

All the prices are by mail, postpaid.

EARLY WHITE FLAT DUTCH (Strap-leaved).- -An old standby, and one of the most popular early varieties in the south for eicher spring or fall plantings. Of medium size and a quick grower. is fiat with very small fine tap-root. Flesh and
skin pure white; fine grained and sweet. Pkt., 10c; oz., 15c; 1/4 lb., 25c; ib., 75c.

RED, or PURPLE-TOP STRAP-LEAVED.-The most widely cultivated and best-known variety. Used largely for sowing broadcast among corn and potatoes. It is round and fiat, white on the bottom and a reddish purple above ground, and a very quick grower. It is esteemed as a fine table variety. Pkt., 10c; oz., 15c; $1 / 41 \mathrm{~b} ., 25 \mathrm{c}$; (75.

SEVEN-TOP.-The most popular variety for winter and early spring "greens" in the South. Very hardy, growing all through the winter. Can be cut at all times. be sown from August till December and in early spring. Pkt., 10c; oz., 15c; 1/4 1b., 25c; $1 \mathrm{~b}, 65 \mathrm{c}$.

EXTRA EARLY WHITE EGG. $\rightarrow$ A Turnip of the sweetest flavor ready for use in six weeks from the time of sowing with good seasons. In quality it is the finest of all While the size is small, compared with some others, its earliness and quality more than make up for any lack of size. Skin and fiesh are pure white; bulbs almost egg-shaped solid, fine-grained and a good keener. Very attractive when bunched for market. Pkt. $10 \mathrm{c}$; oz., 15c; $1 / 4 \mathrm{lb} ., 25 \mathrm{c}$; $1 \mathrm{~b} ., 85 \mathrm{c}$.

RED-TOP WHITE GLOBE.-One of the largest and finest of all the Turnips; beautiful globe shape, with pure white flesh and a red or purple top. Of very rapid growth for a globe variety, and will produce more to the acre than any known variety. growth for a globe variety, and will produce more to the acre than any known vali
May be sown either broadcast or in drills. Pkt., 10c; oz., 15c; $1 / 41 \mathrm{~b} ., 25 \mathrm{c} ; 1 \mathrm{~b} ., 85 \mathrm{c}$.

EXTRA-EARLY PURPLE TOP.Earliest Turnip in cultivation and a splendid variety; bulb white, flat, of medium size, with a bright purple top; one of the sweetest and finest flavored of summer sorts. Pkt., 10c; oz., 15c; $1 / 4$ lb., $25 \mathrm{c} ; 1 \mathrm{~b},, 75 \mathrm{c}$.

AMBER GLOBE.-Flesh is beautifully yellow, very fine-grained and very sweet. Will grow to very large size in the South; is one of the very best keepers for winter use. Pkt., 10c; oz,, 15c; $1 / 41 \mathrm{lb}$., $25 \mathrm{c}$; $1 \mathrm{~b} ., 75 \mathrm{c}$.

WHITE GLOBE. - Color pure white; shape round; size large; solid, quick in growth for a large Turnip, producing a great weight to the acre. Rapidly growing in popular favor, more especially as a late winter and spring variety. Productive, hardy and closely resembles in size and shape the popular Purple-Top Globe. Pkt., 10c; oz., 15c; $1 / 41 \mathrm{~b} ., 25 \mathrm{c} ; 1 \mathrm{~b} ., 75 \mathrm{c}$.

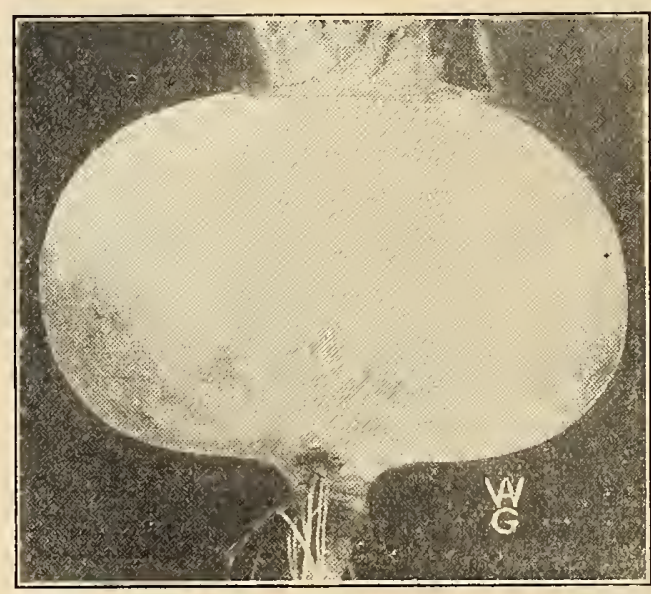

Eariy White Flat Dutch Turnip
SOUTHERN PRIZE or DIXIE.-. Makes large, round, white Turnips in addition to solid; hardy and needs no protection, the most popular winter and spring salad Turnip grown. Pkt., 10c.: oz., $15 \mathrm{c}$; $1 / 4$ lb., $25 \mathrm{c}$; 1b., $65 \mathrm{c}$.

LONG WHITE COWHORN. Roots are long and carrot-shaped. Onethird to one-half of the root is formed above ground, A deep rooter, resisting drouth. Flesh pure white, fine-grained, sweet and of good table quality. Hardy. By many it is sown in combination with Dwarf Essex Rape for winter pasture. Pkt., 10c; oz., 15c; $1 / 4$ 1b., 35c; 1b., $\$ 1.00$.

YELLOW GLOBE.-A splendid sort for general crop; grows large; a good keeper, with bright, yellow flesh. Pkt., 10c; oz., 15c; $1 / 4$ lb., 25c; lb., $75 \mathrm{c}$.

IMPROVED GOLDEN BALL.One of the sweetest and most desirable y ellow-fleshed varieties; of medium size; a perfect globe shape, with firm, hard, yet rich and sweet fiesh; it has no equal as a table variety; keeps well. Pkt., 10c: oz., 15c; $1 / 4$ lb., 25c; 1b., 75c.

\section{RUTABAGA}

The fiesh of the Rutabaga is firmer and richer, generally speaking than that of the turnip. of which family of plants it is an important member. They are usually more highly prizod for winter markets, whereas the turnip comes into value for the spring and early fall markets. Perhaps the most general use of the Rutabaga, however, is for the feeding of stock. In many sections it forms a valuable adjunct to the ordinary stock food, and its nutritive value has been frequently demordinary stock food, and its nutritive value has been frequently dem-
onstrated. Because of the fact that the yield is usually very heavy, a stock food is provided that is at once cheap, rich, succulent and nua stock

CULTURE.-They like a rich, well-prepared soil, and should be sown in drills 30 inches apart, and thoroughly cultivated. When bulbs begin to form, throw dirt to the bulbs, keeping them well covered. This prevents the objectionable neck, so often seen on Rutabagas. They should be given room to allow development and to this end should be thinned out to about 8 inches in the row.

IMPROVED AMERICAN PURPLE-TOP RUTABAGA.-This strain is of American origin, bred to a smaller top and short neck. The bulbs are of great size, yellow-fleshed and purple crown, one of the most desirable varieties now cultivated. Pkt., 10c; oz., 15乞; $1 / 1 \mathrm{lb} ., 25 \mathrm{c}$;
$1 \mathrm{~b} ., 85 \mathrm{c}$.

The War Garden shouid have taught everyone that own veretables. Profit by your exnerlence. DON'T QUIT THE WAR GARDEN.

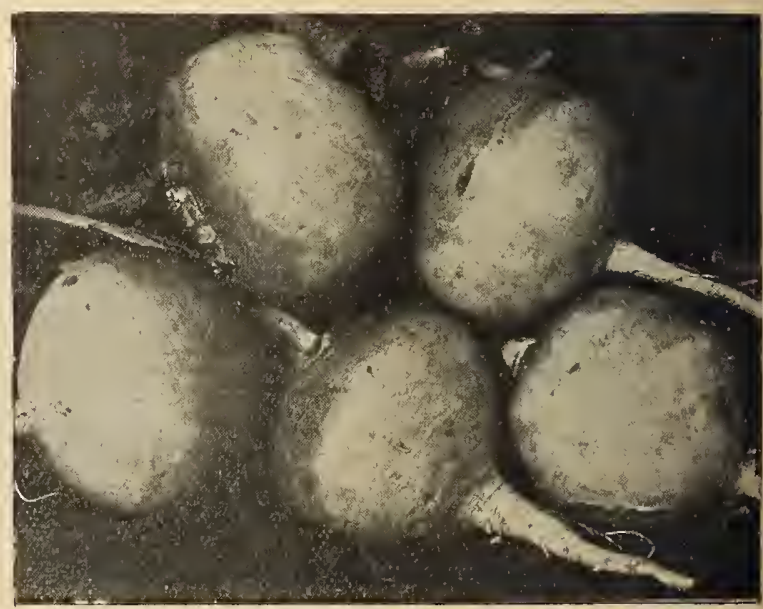

Improved American Purpie-Top 2 Rutabaga 


\section{Martin's Hy-Test Flower Seeds}

Regardless of what your occupation may be, or how meager your experience, there are flowers that any one may grow there are flowers that any one may grow
successfully from seed. You should devote

Ali Flower seeds put up in 5c and $10 \mathrm{c}$ packets and sent postpaid. Speciai prices in buik.

\section{ALYSSUM, SWEET}

This is a very hardy annual, blooming early in the spring, covering itself with innumerable clusters of small, pure white very delicate. Grows about 1 foot high.

\section{ASTERS}

Beautiful and popular annuals, desirable for beds, being in bloom when most other plants are nearly over. Very useful for cut

\section{Mixed.-Dwarf and TaiI.}

\section{CALLIOPSIS, or COREOPSIS}

Beautiful showy summer bedding annuals, with large, bright flowers of golden yellow, varied with rich brown. Excellent for cutting and decoration.

\section{CANDYTUFT}

Popular favorite, flowering profusely the whole summer. Very valuable for edgof white and various colors. Heirht, 1 foot.

Mixed Coiors. - A splendid mixture.

\section{CYPRESS VINE}

A tender climbing annual, with soft A fern-like foliage and
Ohoice mixed colors.

\section{FOUR O'CLOCK}

A hardy annual of easy culture, growing about 2 feet high. The plant is free-flower ing, bearing blossoms in a great variety of colors and stripes.

\section{HYACINTH, Or JACK BEAN}

A tall, twining plant, often 10 to 20 feet high. Bears purple flowers in long, erect racemes.

\section{MIGNONTTE}

Superb Mixture.-Hade up of the newest and best sorts. It ircludes all shades of color and varieties which produce the of color and variet

\section{MOONFLOWER (EVENING GLORY)}

Grows 30 to 40 feet; covered every evening and cloudy day with large white flowers, 4 to 6 inches across.

\section{MORNING GLORY}

Imperiai Japanese.-One of the grandest climbers, the flowers measuring 4 to 6 inches across, in a limitlcss variety of colors and markings.

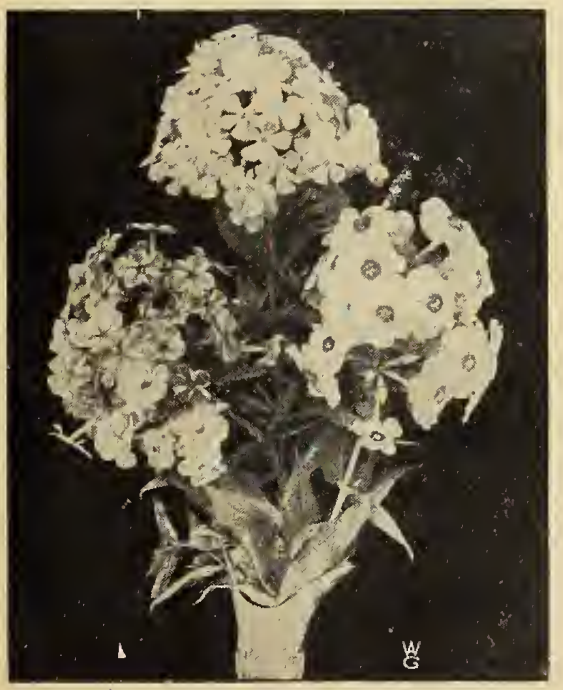

Phiox.

\section{NASTURTIUMS}

In the past few years wonderful improvements have been made in thcse favorites. Types and colors have been added until in our mixtures we have a magnificent array of gorgeous colors. Nasturtiums do best in a loamy, well-watered situation.

Tail and Dwarf Varieties.- $1 / 4 \quad \mathrm{lb}$., 35c; 1 1b., $\$ 1.00$.

\section{PANSY}

Pansies thrive best in a moist, shady Pansies thrive best in a moist, shady be sown in the autumn for early spring blossoms, or can be sown early in the year for good flowers later in the spring. The plants must be transplanted twice in order to get the largest flowers; once from the seed box to a chosen bed, and again to the open garden. This is important for large size pansies; use manure liberally. The blossoms are usually larger in the spring and again in the fall, and while they bloom freely all summer, the blossoms are small during the hot

Our Mixed FIowers of all shades and markings. A splendid mixture.

\section{PETUNIA}

The richness of color. duration of bloom and ease of culture will always make Petunias popular, especially for massing in beds.

Doubie.-A splendid strain, producing a large percentage of double fringed flowers in bright colors, beautifully marked. Mixed colors.

Singie.-A choice mixture; all colors.

\section{PHI OX}

Fine Mixed.-These favorites are dazzling in the effect they give in massing. A wide range of colors

\section{PINKS}

Finest Mixed.-Thnse charming, oldfashion'd flowers ara gr at f*vorite's. Our mixture is the fincst procurable.

\section{POPPY}

Poppy Mixture.-A grand mixture of all the newest and best double and single annual Poppies, covering every color, from dcep scarlet to pure white. The wonderful variety and brilliant colorings make a most effective display.

\section{PORTULACA}

Succeeds in a sunny situation, and produces flowers of almost every color in the greatest profusion. The double is especially beautiful. Sow when weather becomes settled and warm. Height, 6 inches.

Singie.-Large-flowering, mixed colors.

Doubie. - Extra-double, all colors mixed. SUNFLOWER

Doubie.-Double yellow varieties 3 to 5 feet high. Exceedingly beautiful.

\section{SALVIA}

Brilliant flowers are borne in profusion from early summer till frost. Excellent for cutting. Seed sown early in the house produce better plants than from cuttings. produce bette
Height, 3 feet.

\section{SWEET PEAS}

Cuiture.-Some time before planting dig out a trench a foot deep, put in several inches of well-rotted manure and cover with six inches of earth. Early in February open the row three to four inches deep, drop the seeds (about four seeds) every three inches, cover about two inches. and two or three times during the season bank the soil against the roots. The white-seeded kinds are tenderer than the black-seeded, and should not be planted too early. They may also not pe planted in October, November and Dece planted in October, November and Degive slight protection and they will become well rooted and grow off at the first ovening of spring and produce an abundance of of spring and produce an abundance of
bloom earlier and for a longer season than spring plantings.

Don't gather the biooms grudgingiy the more you cut them the better and ionger they bioom.

Eckford's Mixed.-An unsurpassed mixture, combining every shade and type. choice large-flowering sorts, the colors being

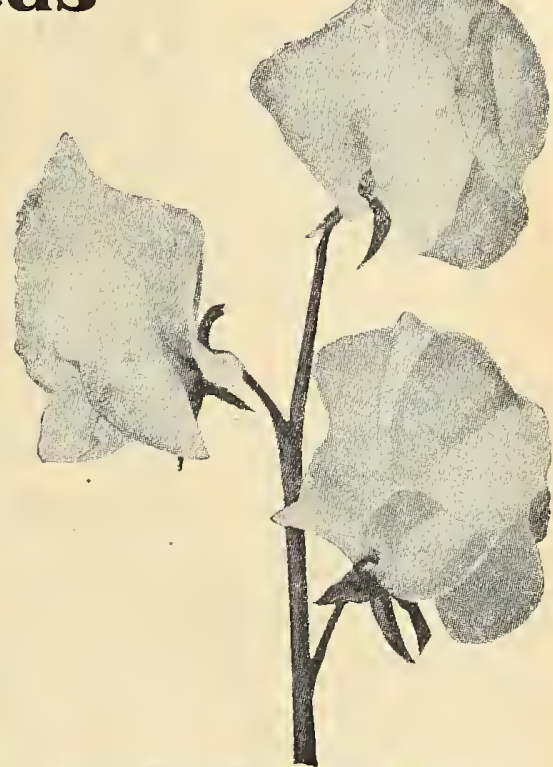

Sweet Peas-The Garden Beauties

distributed as evenly as possible throughout For diversity of color, size of flowers and beautiful forms, this mixture is unexcelled $1 / 41 \mathrm{~b} ., 35 \mathrm{c} ; 1 \mathrm{lb}$., $\$ 1.00$.

\section{THUNBER GIA}

A rapid climber, growing 4 to 6 feet high. Splendid for trellises, fences, etc. bearing beautiful fowers-white, yellow and buff, with black eye.

\section{VERBENA}

Annual for beds, borders, massing, window-gardens, covering mounds, etc. Flower of most brilliant colors, blooming from early summer till late fall. Soak a fow hours and sow in boxes indoors, trans zinnia (Youth and oid Age).-Few flowers are so easily grown from seed. or bloom so abundantly and continuously. Finf for beds and borders: in fact in any location.

\section{FLOWER SEEDS}

We carry the following Flower Seeds in bulk which are selected for being the highest quality and we know will give just the results desired:

Sweet Peas-Eckford's

Mixed. Mixed Col

ors...........

Knight, Deep Ma-

roon

roon Peas-Bianch

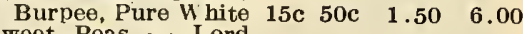

weet Peas - Lord

Blue.

az. $1 / 4$ lb. lb. $5 \mathrm{lbs}$

sweet Peas - Queen

of

Salvia, or Scarlet Sage

Verbenas- - Miammoth

15c $50 \mathrm{c} \quad 1.50 \quad 6.00$

Finest Mixed.

Zinnias - Giant Double, oz. 1/4 lb. $1 \mathrm{~b}$.

Finest Mixcd. all colors $\$ 1.00 \$ 3.00 \$ 10.00$ Zinnias - Giant Double.

Golden Yellow ......

$1.00 \quad 3.00 \quad 10.00$

Zinnias - Giant Double,

Scarlet.......... $1.00 \quad 3.00 \quad 10.00$

asturtiums, Mixed Col- $10 \mathrm{c} \quad 35 \mathrm{c} \quad 1.00$

Nasturtiums, Mixed Col- $10 \mathrm{c} \quad 35 \mathrm{c} \quad 1.00$

ors. Dwarf......... 10c 35c 1.00

$\begin{array}{cccc}\text { Pansy-Mixes and markings.. } & 75 \mathrm{c} & \mathbf{3 . 0 0} & 10.00\end{array}$

Giant Pansies in separate colors:

Giant Adonis-Lavender Blue.. pkg. $\$ 2.00$

Giant Freya-Rich Wine Color,

edge white.

Giant Psyche - Purple violèt.

$50 \mathrm{c} \quad 2.00$

edge white. 


\section{E. A. MARTIN SEED COMPANY, JACKSONVILLE, FLORIDA}

\section{$B \cup L B S$}

The first step is to secure good Bulbs of good size, clean, sound and solid. Don't buy bulbs at "Bargain Prices." Such usually have been carried over in cold storage from the previous season or have been planted out in spring, then dug in the fall and sold at a low price. You cannot get fine flowers from such bulbs.

We have our bulbs especially grown for us by the most competent growers, and our

\section{SUGGESTIONS FOR GROWING HYACINTHS}

Bulbs should be planted in Florida from October to January. However, later planting meets with success, but the above-mentioned months gi re better results.

\section{OUTDOOR CULTURE}

The soil should be moderately rich. or made so with well-rotted manure or bone-meal fresh manure should not be used, as it will injure the bulbs. Good results cannot be obtained without free drainage. The common plan is to dig up the soil to a depth of about 6 inches and then fill in with a couple of inches of sand or gravel. The bulbs can be planted on this and surface soil filled in over them.

\section{INDOOR CULTURE}

Bulbs intended for blooming indoors can be planted from September until January; the earlier they are potted the better. After potting the bulbs shnuld be sot in the open the earlier they are potted the better. After potting. the hulbs shnuld be sot in the open ing weather, then be br,ught into a csol greenh use, cell $r$ or $r u r m$ where the temper ture will nat go abuve fifty degrees. An occ si n.l witering will be required after th y are

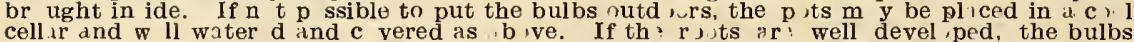
can $b$, br ught into a co l room, and the $f$ linge and fl wwer spikes will $d$ vel p quickly. By f ll Jwing these directions one can have a supply of flowers until after Easter, if the puts aro brought to light at intervals of two or three weeks.

\section{GROWING HYACINTHS IN WATER}

A novel way to grow Hyacinths is by setting them in glasses, just allowing the bottoms of the bulbs to touch the water, then placing the glass in the dark until the bulbs are thoroughly rooted. The water should be changed every ten days, and a small piece of charcoal plared in the bottom of the glass will prevent the water from becoming foul.

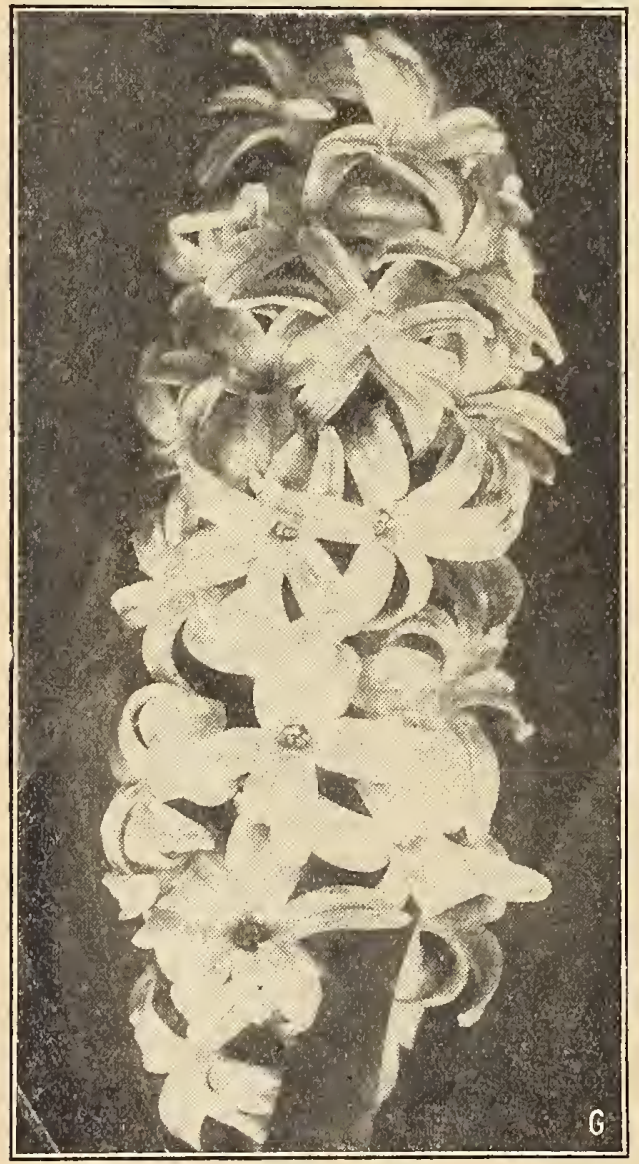

myacinth

\section{ROMAN HYACINTHS}

The flowers, while smaller than those of the Dutch 1 yacinths. are borne in much greater abundance, each producing about six graceful spikes of bloom, whi h makes it a most valuable sort for cutting. White Roman Hyacinths are the ki $\mathrm{d} m$ mst largely used for cut flowers. They are the earliest to bloom and are dciliuusly fragrant. We quote as follows by mail postpaid:
Each, ,0e; per doz., $\$ 1.00$

Roman Hyacinths, White.

\section{EXTRA SELECTED NAMED DUTCH HYACINTHS}

The varieties offered in this list have been selected as the varieties which have proved the most satisfactory. We quote as follo,vs by mail, postpaid

Single Dutch Hyacinths, white...............Each, 10c; per doz., 7 ic Single Dutch Hyacinths, Biue . . . . . . . . . . . . . Each, 10c; per doz., 7 jc Single Dutch Hyacinths, Rose or Pìnk. ...........Each, 10c; per doz., 7 ic Double Dutch Hyacinths, Blue, all shades............. Double Dutch Hyacinths, Rose or Pink . . . . . . Each, 10c; per doz., 7 ic Double Dutch Hyacinths, Red, all shades . . . . . . . . . . Each, 10c: per doz, 7 ic Double Dutch Hyacinths, white, all shades...........Each, $10 \mathrm{c}$; per doz., $75 \mathrm{c}$

\section{PAPER WHITE NARCISSUS}

For planting among shrubbery, in unused corners or for naturalizing in grass where they remain undisturbed for years, these are without doubt one of the bes hardy bulbs, coming into bloom early and supplying an unfailing source of cut flowers. The Paper White Narcissus is very satisfactory for outdoor blooming.

We quote as follows by mail, postpaid.

8c each; 60c per doz.

\section{FREESIAS}

The justly popular Freesias are greatly prized for the dolightful fragrance of their delicately colored flowers, which, when cut, will remain in good condition for a lon time in water. They are easily grown or forced in good loamy sil, with an admi stur of leaf-mold and sand. For the information of all not acquainted with these bulbs we may say that they are quite small but produce large blooms in comparison to their size. 6c each, 50c per doz.

\section{FREESIA REFRACTA ALBA}

The body of the flower is pure white, with lower segments spotted lemon-yellow. Their fragrance is remarkable and very lasting.

\section{DAFFODILS}

DAFFODILs, Emperor.-A magni icent flower of great substance, having an immense trumpet of clear, golden yello $\mathrm{N}$, and broad primrose yello $N$ perianth: very early splendid for forcing or planting out of doors. Price by mail. postpaid: Each, 10c; \$1.nn mor inz.

LAFFODILS, Poeticus Ornatus.-Pure white, yello v cup, margin deep scarlet: nearly a month earlier than Poeticus: splendid forcer. It is not so siveetly perfumed as Poeticus, but is large, showier and earlier. Price, by mail, postpaid. Each, 10c per doz., \$1.00.

If your order is for 100 Bulbs or over, write for special price. 


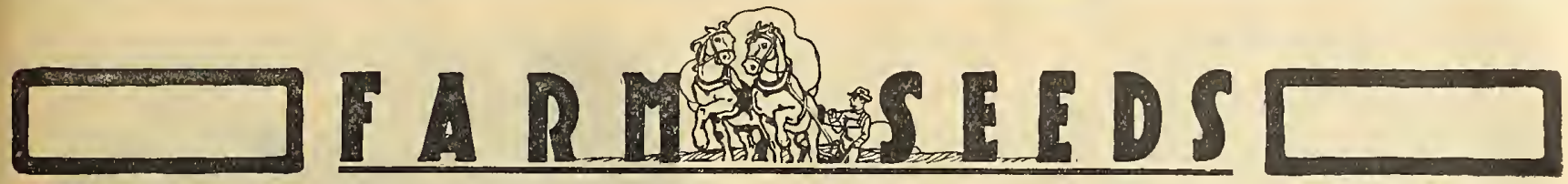

\section{FORAGE AND GRASS PLANTS}

\section{Florida Can Lead the World in the Production of Hay}

While all know that Florida, of all states in the Union, has shown the most remarkable growth of fruits, vegetables and tobacc , culturc it is not so well known that she is far ahead of other states in her gre at wealth of forage and grass plants.

Time was when it was not thought possible to grow grass in the state. That seems a great while ago. Certain it is that Florida is the richest grass and forage state in the Union. So many of these grasses and forage plants are, too, perennials-once planted, always planted, and so many are legumes and soil-enriching.

Here is a partial list: The velvet bean (legume) has its best habitat in Florida; Speckle Velvets, Whites, Lyons, Early Y kohama and New Chinrse. And since the Yokohama ripen in September and mature as for North as North Carolina, Florida should build up a good industry in growing these beans for the latitud's farther north where other velvet beans will not do well. The Speckle. Velvet, as is well industry in growing these beans for the latitudes farther north where other velvet beans wiln not do well. The speckle. known, produc's more vine and stores more nitrogen in the soil than any other known plant. For winter grazing and for himus making and land upbuilding it has no equal. The White Chinese, a month earlier, and more proliffc in beans and equally prolific in vines, may sup-

Equally important and valuable in Florida is beggar weed, a legume. Coming up in June in all cultivated flelds, reseeding itself each year and practically a perennial, good for hay, or pasture, or green manuring, growing eight feet high and making more than 40,000 pounds of green stuff per acre, and rich in feeding nutrients. Florida could not and does not want any better crop than heggar weed.

In cowpeas the wilt-resisting varieties, the Iron and the early two-crop Brabhams do well and serve best. In Florida the peanut (lcgume) which is as much of a forage as a nut plant. is just as much at home as in North Carolina or Virginia. Johnson grass does well in Florida. So does the legume, kudzu.

A wonderful product whose best habitat is Florida, too, is Japanese sugar cane, a perennial with ten or fifteen stools or suckers from each joint of the stalk as planted, making ten or twelve tons of cane per acre good for forage or making fifteen gallons of finest syrup per ton.

The African hog goober is also adapted to the state, as also are chufas. Teosinte, fifteen feet high, stooling thirty to fifty stools per seed, $t$ wenty tons or more green stuff per acre, making 225 pounds of green stuff from one seed. Florida is the home of this wonderful plant. Bermuda, the perennial, does well, too, in the state, as do also the remarkable perennial and green-all-the-year grasscs, St. Augustine, St. Lucie and Carpet grass.

The li : e stock industry has grown so rapidly during the last few years that Florida is now regarded as one of the most important live stock states in the South. Florida live stock men are importing some of the finest blooded cattle and hogs the country affords.

The largest sale of registered cattle ever made in the great southwest was made to a Florida live stock man.

To keep this live stock up to standard they must be properly cared for. This can best be done by planting fall grasses, etc., for your winter grazing.

\section{MARTIN'S HY-TEST OATS}

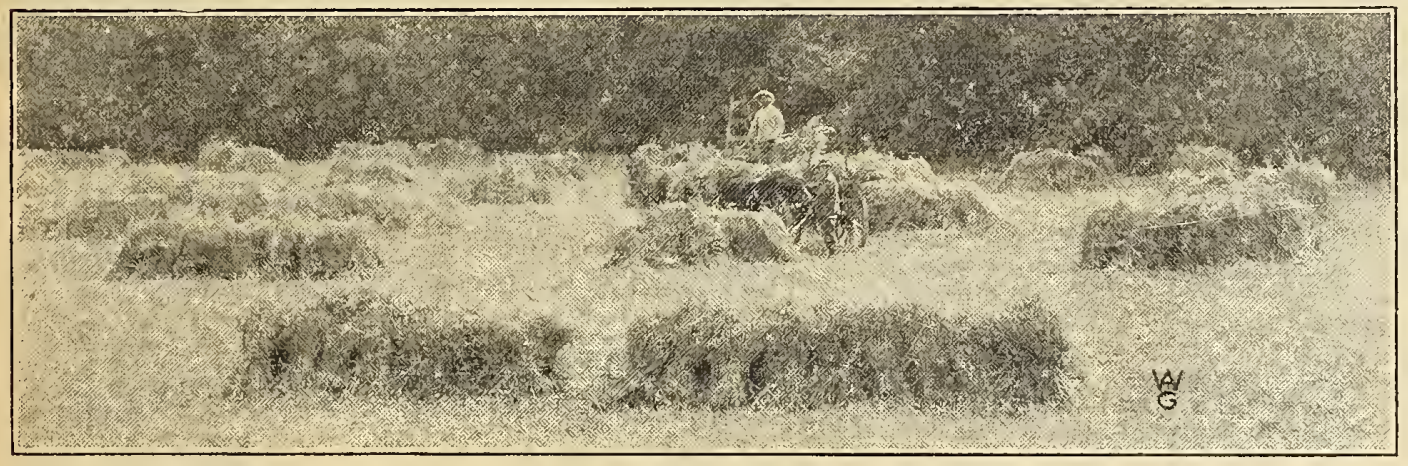

Inferior Seeds are at the

most

expensive at any price. Plant only the very best seeds. Martin's "Hy-test" seeds will Field of Fuighum Oats please you.

\section{Prices subject to change without notice Write for prices in large quantities From 2 to 3 busheis to piant an acre}

\section{FULGHUM OATS.}

This new Oat has won a great reputation in the last two years and we cannot recommend it too highly to our customers. The grains and stalks are as large as the Appler and are double the size of the Texas grains. 1t is about threc weeks earlier than the Appler and is as early as the light, thin, unsatisfactory spring "Burt" Oat. It is sturdy in habit and not apt to blow down. Has long drouthresisting taproot. Natures evenly. The earliness of the Fulghum resisting taproot. Matures evenly. The earliness of the Fulghum crops and for early spring feeding. It is rust-proof cold-resistant crops and for early spring feeding. It is rust-proof, cold-resistan and quite beardless and drills in the machinc hetter than Appler.

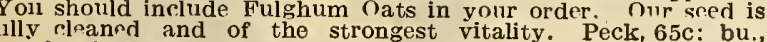
carrfully clrannd and
$\$ 2.0$ ): 5 bu luts, $\$ 1.75$.

Note-For Winter Grazing.-In Florida and the Southern states there is an increasing demand for quick grazing crops. Oats take an important place in supplying this demand and our demonstration and information has proven the Fuighum to be one of the most satisfactory varieties that can be planted. While we emphasize this Oat for grazing we must not take from it any of its good qualities as a grain producer and we dun't hesitate to say it is the best general purpose oat that can be planted. Our seed of this variety has been carefully selected and espe:ially grown for us this variety has been carefully selected and esperially grown for us for years and are the highest quality select d seed nats that can be
produced. The pedigree of the seed must be considered. Martin's produced. The pedigree of the seed $\mathrm{m}$.

BURT-The Burt Oat is an extremely early variety, producing an abundance of straw of good length. It is the best poor-land oat known, also the safest and earlirst to plant in the spring. The grain is small, light, slim and, under favorable weather conditions. is of a very light straw-color. A good percentage of the grains have beard, and are frequently borne in clusters of two. The genuine Burt Oat is a sure leader, coming to maturity ten days to two weeks before Rust-proof. Two bushels of Burt Nats should be used in seeding an acre, and, where they are to be made into hay, three bushels will be found profitable. We sell great quantities of these oats for fall planting, and when properly put in, they go through the winter all right and come in extremely parly in the following Price on application. Peck, f5c; bu., $\$, .00 ; 5$ bu., $\$ 1.75$.

(Oats continued on next page.) 


\section{E. A. MARTIN SEED COMPANY, JACKSONVILLE, FLORIDA}

\section{OATS - Continued.}

TEXAS RED RUST-PROOF.-There is no better Oat than the Texas Ked Rust-proof, providing one gets the genuine Uat, grown in the State of Texas. It is safe to say that 75 per cent of the Oats sold as Texas Rust-proof never grew in that state. Farmers should be more careful in purchasing their seed Oats. The Texas Oats are heavy grains, nearly all of them having a distinctive beard. Color varies, according to the season. They are largely planted in the spring and early fall. Two bushels should be sown to an acre. Peck, 65c: bu., \$1.75: 5 bu., \$1.50.

APPLER.-Equally well adapted for sowing in the spring and the fall. but when put in the spring, should be sown before th middle of Narch. It makes a strong, quick-growing Oat, with bunchy heads and heavy grain. While originating in the state of Georgia, this ()at has been grown to a considurable extent both in this suction and in other Southern states, and has proven to be on of the best and most reliable of rust-proof Oats for the South. Peck, 65c: bu., $\$ 1.75: 5$ bu., $\$ 1.50$.

THE FAMOUS 100-BUSHEL. - The claim for this Oat is that it is an improvid type of southern Oat. rust-proof. has heavy grains. large straw, and is extremely productive. While the claim for it is extra productivity, we certainy cannot, nor can anyone else, guarantee 100 bushels to the acre, but it should come as near or nearer to it than many other Oats on the market. Peck, 65c: bu., $\$ 1.75 ; 5$ bu., $\$ 1.50$.

\section{BANCROFT OATS.}

Our experiments with this improved strain of rust-proof oats last year proved to be one of the best and largest yielding and surest cropping of spring oats. It matures in about ninety-five days, and is a very superior variety, both in yield and in appearance of grain. Wherever they have been gro rn they have made a decid ad impression as a most superiur cropping oat. We recommend them to our customers believing that they will become one of the leading and standird varieties in a very short time. Peck, 65c; bu., $\$ 2.00 ; 5$ bu., $\$ 1.75$.

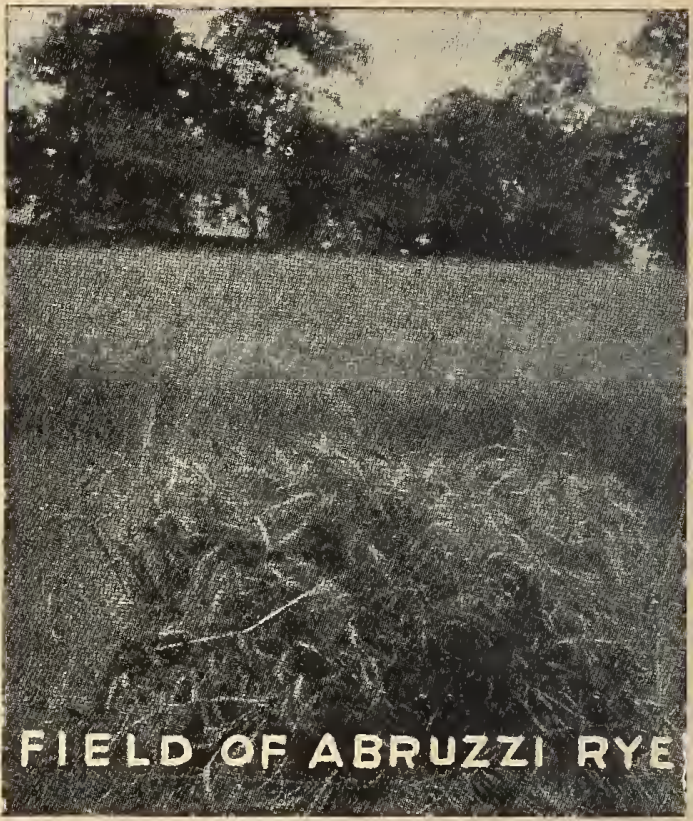

Naples, and brought with it this record: "Abruzzes, a superior rye grown in the Abruzzi Province, a mountainous district east of Rome. This strain is one of the best grown in Italy, having made an average yield of 28.2 bushels per acre for a period of ten years." This rye was tested by the United States Department of Agriculture found to tested by the

Abruzzi Rye is far superior to the ordinary rye varieties. In carefuliy conducted tests, we find that it will give from two to three times the amount of pasturage or forage that our ordinary varieties

In addition to its heavy yields, it possesses the distinct advantage of growing upright, making it easy for the animals to graze. It does not lie flat on the ground. It grows off upright from the very start.

WE DO NOT KNOW OF ANY CROP THAT WILL GIVE AS MUCH GRAZING DURING THE WINTER AS ABRUZZI RYE. Qt., 25c.; pk., $\$ 1.25$; bu. $\$ 4.00$.

\section{WINTER BARLEY}

Excellent pasture for winter and early spring, as it can be grazed without injury. Sow at rate of $1 \frac{1}{2}$ to 2 bushels per acre during fall or early winter. Pk., $\$ 1.00$; bu., $\$ 3.75$.

Department of Agriculture while on an exploration trip through introduced for the first time about January, 1900. It came from

\section{Dwarf Essex Rape for Winter Forage}

In drill, 4 to 5 pounds to an acre; broadcast, 7 to 8 pounds. Lb., 30c; 5 to 10 lbs. 25c per lb.: 15 lbs. $171 / 2 \mathrm{c}$ per $\mathrm{Ib}$. for feeding hogs, dajry cows, and sheep, as it will produce many tons of good nutritious feed per arre at a time of the year when green feeds are scarce. Throughout a large portion of thr State, farmers and stockmen rould, with advantage, grow more of the succulent forage crops for fording stock during the autumn and winter months, when the supply of grass and other green forage is often limited. Such crops may usually be grown on land that bas already produced an early matiring crop. One of the best of these succulent crops is perhaps Dwarf Essex Rapo-a plant closely related to the cabbage, turnip and mistard.

The seed may be sown at any time from the fifteenth of September to the fifteenth of December. The farmers of West Florida will find it best to plant during the latter part of September, while those of Central and South Florida can plant later in the season.

\section{Sand or Winter Vetch}

If wanted by mail, add for postage.

The Sand Vetch is one of our most valuable forage plants-in fact, the most valuable of all to furnish green forage in winter. It is in general use in this section by dairymen. It is a nutritious feed. fattening and, at the same time, largely increases the flow of milk. Vetch should be sown from August to December at the rate of thirty to forty pounds per acre, with three-quarters to one bushel of rye or winter oats. Vetch is a trailing plant and needs something like rye, oats or wheat to support it, holding it well off the ground and making it easier to harvest and cure. Lb., 40c. 5 lbs., 35c: 10 lbs. and over, $32 \mathrm{c}$.

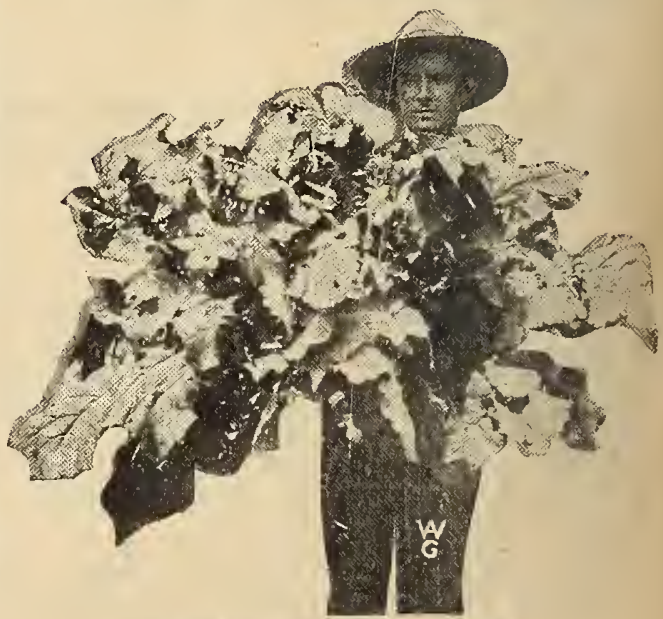

One Plant Dwarf Essex Rape 


\section{Martin's Hy-Test Grasses ITALIAN RYE GRASS}

Sow from 6 to 8 bushels per acre for lawns.

One of the most valuable grasses for fall planting, a quick grower, an annual, dying out the first summer. It is used mostly in Florida as a lawn grass, and makes one of the quickest growths that can be planted. It is generally sown over Bermuda or other lawn season, and the sale is steadily increasing. Bus., \$4.00.

\section{RHODES GRASS}

Rhodes Grass, scientifically known as Chloris gayana, is a good hay and pasture grass and does rery well on good farm lands. It stands drouths very well. It is better adapted to truck than to cotton lands.

The earliest record that we find of the grass in this country is in 1902 , when Dr. David G. Fairchild, Agricultural Explorer, secured a bag of the seed in south Africa. It was then attracting a great deal of attention in that country.

\section{TIME OF SEEDING}

Experience with it in Florida indicates that April and May in the spring. or October and November in the fall. would be the most favorable times for seeding in Northern Florida. This same time would probably suit Central and Southern Florida as well as any other time of the year. The seed should be sown in a seed bed thoroughly prepared and covered very lightly. It must, however, be in contact with moist soil to germinate readily. Under favorable condi'ions germination will take place in about three days, and the seedlings may be expected to show themselves above ground in a week.

With good seed, $10 \mathrm{lbs}$. to the acre will be sufficient for a good stand. Prlce, 75c per lb.

\section{SUDAN GRASS}

Sudan Grass is without doubt one of the best grasses. It has proven a remarkablc success wherever it has been sown, and is destined to become one of the standard summer grass and forage crops, and that it will largely supersede millet and other summer forage crops, is confdently predicted. Aillet only produces one crop a year; Sudan Grass will produce two or three good cuttings each season, and cures up splendidly. making a most nutritious and desirable forage or hay crop. From our own and our customers experience we strongly recommend liberal seedings of this grass every where that a summer forage or grass crop is

SOWING THE SEED.-The seed should not be sown until the ground and weather Sown soed should not be sown until the ground and weather in drills from is inches to two feet apart at the rate of about $10 \mathrm{lbs}$. per acre, and cultivated. or can be broadcasted or drilled thickly at the rate of 25 to $30 \mathrm{lbs}$. per acre.

The hay should be cut as soon as the grass is fully headed, and early cuttings are especially ad isable where more cuttings per season are expected. The grass can be cut with a mower. the same as other grasses. Sudan Grass stools out thickly after the first cutting. and makes a thirker growth for the second and third cuttings than for the first cutting.

Sudan Grass is an annual, and requires to be sown each season.

Pound, 4le.

Write for prices on large quantities.

\section{BERMUDA GRASS}

One of the most valuable pasture grasses.

Sow at the rate of 7 or 8 pounds per acre.

This is a most valuable perennial pasturage grass all through the South, and also produces good yields of hay. It is rery well adapted to light soils. and in some sections of the South is the only pasturage grass that will make a good sod on this class of soil. It also does very well on clay and loamy soils. It is rather late in starting in the spring, but stands hot, dry weather remarkably wcll, making a most valuable summer pasturage grass. It
will furnish more summer pasturage during hot, dry spells than any other grass we have

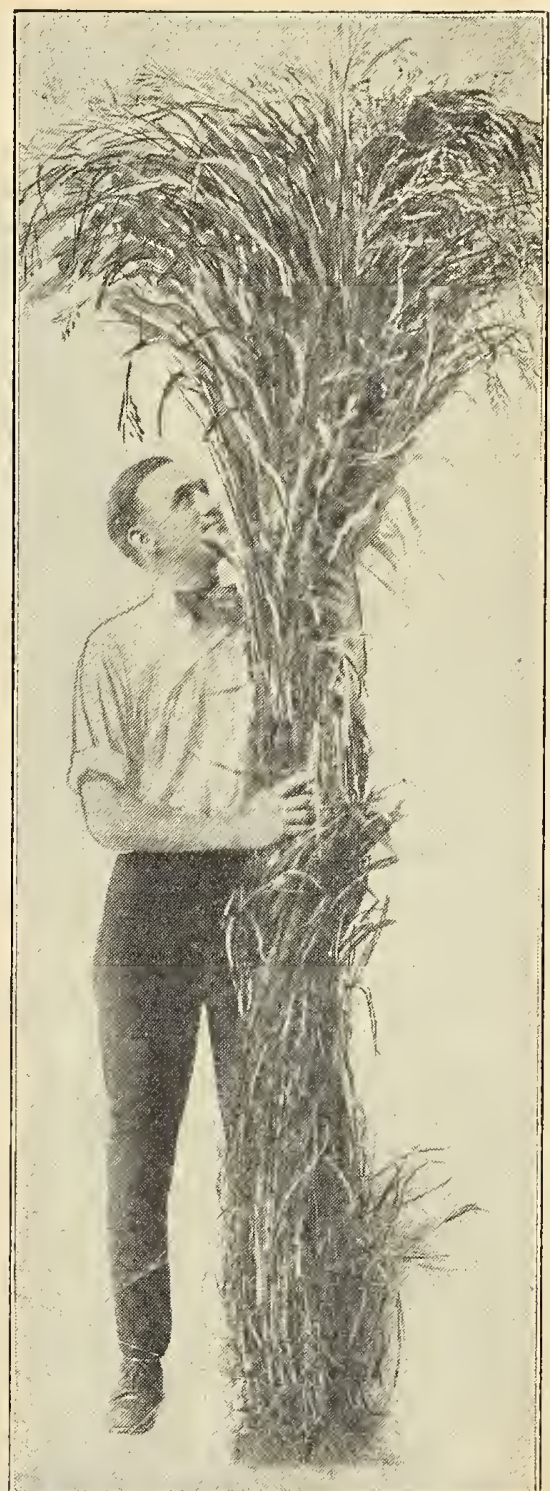

Sudan Grass Fasi yru...eng and heavy yielding Grass ever had experience with. It is rather difficult to eradirate when once estatlished, but this

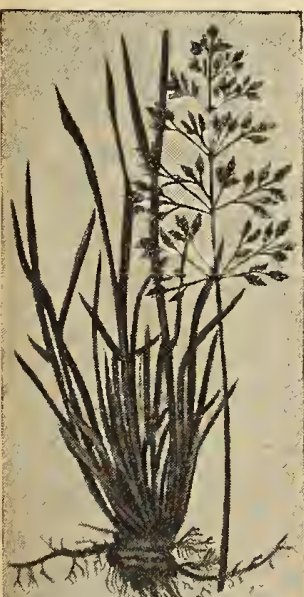

KENTUCKY BLUE GRASS

Kentucky Blue Grass should be included in all Lawn or Pasture Mixtures is also a strong recommendation wherever permanent grass is desired. Protidcd proper methods are used however, Bermuda Grass land can easily, if desired, be planted in other crops, the only requirement being that the Bermuda Grass sod be deeply plowed and thoroughly inverted. so as to give the crops that are planted on same a good start, when the shade from these will prevent the Bermuda Grass from growing. Lb., 75c. postpaid. Special prices on larger quantities.

\section{KENTUCKY BLUE GRASS}

It is rather sensitive to heat, but not so to cold weather, and on this account does its best in the fall, winter and spring. It grows slowly at first, forms a very compact turf, making a fine pasturage where once established. It is much the best, however, to combine other grasses with it for either lawn or pasturage. Sow in the spring or fall. Lb., 85c.

\section{CANADA FIELD PEAS}

Price on application.

This is in no sense a cowpea, but resembles an ordinary garden or English Pea in looks of seed and growth. It is extremely hardy, a great soil-enricher and makes the most delicious hay. Should be sown two bushels to the acre; it is better, though. to sow with oats or other winter grain to hold the vines up, using one bushel of Peas and one-half the regular quantity of grain. Both are cut at the same time. Will not give satisfactory results in Florida. 
White.-Well known. It forms a thick, close turf, is forms a thick, close turf, is expecially on sandy soils, and should enter into the composition of all lawn mistures. Alone it requires four to six pounds per acre; in mixture. from one to two pounds. $\mathrm{Lb}$ $90 \mathrm{c}$, postpaid.

Crimson. - Recommend $2 d$ for fall seeding and should be more largely used in the southern states. Produces an excellent hay and fine winter pasture. This is one of the
finest of all suil-imisro ing crops. Sow at the rate of 12 to 15 pounds per acre. Per lb., quantities write.

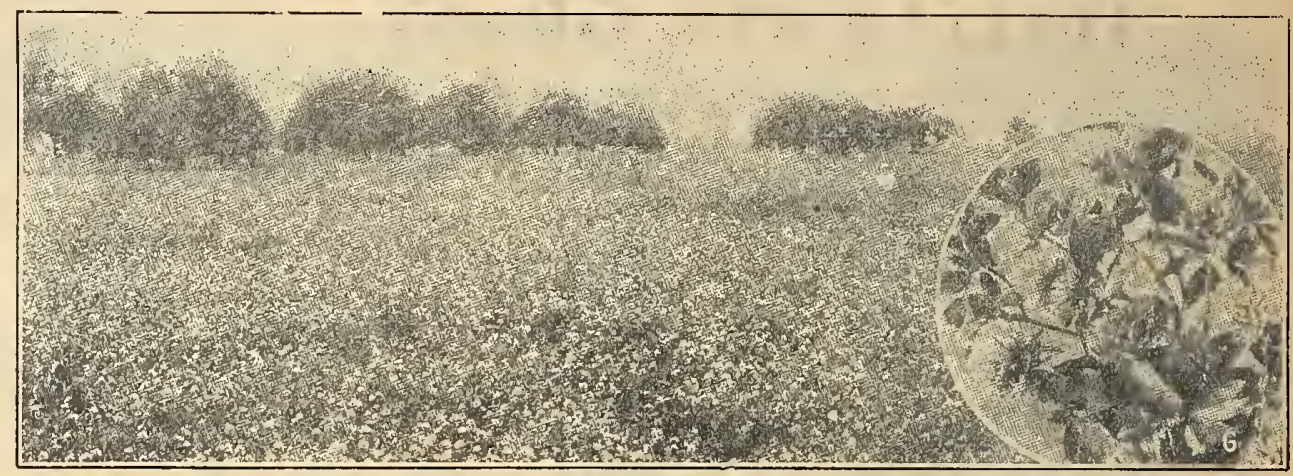

Burr Clover.--Sold in burrs unhulled. A perennial legume, Plant two bushels per acre. Sow July to last of November. Smoothly harrow land and cover only one-third inch in depth. It is better to plant on thoroughly plo ved ground and level and sow the burr directly on top of the land. Our Burr clover is all fresh. Will is not sufficient moisture to wet the seed in the burr, they will no come up. Sprouts with fall rains and matures about ay 20th. Furnishes immense grazing for cattle, sheep and hogs in winter. It akes fine hay. This is fine for a winter pasture and cover crop. In the burr, price per lb., $25 \mathrm{c}$; bu., $\$ 2.00$.

Recleaned 40c. lb., postpaid.

\section{ALFALFA OR LUCERNE}

The broadcast from 25 to 30 pounds per acre. through the southern and middle states, as wherever it succeeds, it proves very con incingly its value as one of the most profitable and satisfactory crops that can be gro $x$ on the farm. Alfalfa will do well on any good loamy soil, but the land must be well and thoroughly prep tred and contain plenty of vegetable matter or be well A heavy application of lime is also of decided benefit. It is also decidediy preferable to sow it on land that has a porous or gravelly subsoil that the roots can penetrate. Alfalfa is a deeprooting plant and will give best results on soils of this character. Has not proven a success in Florida but is recommended for states further north. Lb., 40c, postpaid. Write for prices in large quantities.

Write for descriptive matter and prices on Farmogerm, for better crops of clovers, alfalfa, peas, beans, vetch, peanuts, etc.

\section{MAMMOTH RUSSIAN SUNFLOWER}

The best variety for the farmer. Makes heads nearly double the size of the common kind, and makes a much larger yield of seed. $\mathrm{h}$ ill yield, under favorable conditions, 40 to 60 bushels to the acre. and yields of as high as 125 bushels have been reported under exceptionally favorable conditions. It is highly recommended for poultry and is the best egg-producing food known, and the leaves make excellent fodder, relished by all kinds of stock. 'The seed is a good food for horses. It is claimed in some sections that the

growth of the Sunfower near the house acts as a preventive of malaria. Qt., 30c, postpaid; 1 1b., 35c; 5 lbs., 30c; 10 lbs., 25c, not postpaid.

\section{JAPANESE BUCKWHEAT}

Entirely distinct from all other varieties. It has the advantage of remaining for some time in bloom, and produces seed earlier. It resists drouth and blight very well. The seed is rich dark brown in color and larger than Silver Hull. As much as forty bushels to the acre has been harvested of this variety,
to raise. Lb., 25c, postpaid; bu., $\$ 4.50$.

\section{JAPAN CLOVER Lespedeza striata}

One of the Most Valuable of Grazing and Soil-Improving Crops; Also Makes a Splendid Nutritious Hay Crop

Japan Clover is one of the most valuable crops for the entire South, and is rapidly increasing in popularity wherever it is grown. Its greatest value is as a suil-improving and grazing crop. It is also very largely gro $x$ n as a hay crop, producing large vields of the best hay, superior ia nutritive value to timothy hay.

Once started, it soon spreads and takes possession of the land, making a steady growth of the finest and most nutritious pasturage, greatly relished by horses and all farm stock. It succeeds everywhre throughout the Southern and 7 iddle States, taking pos-
session even of stony hillsides and barren or waste lands. It also session even of stony hillsides and barren or waste lands. It also
does well on low or wet lands, and a combination of Red Top (Herd's Grass) with Japan Clover on this class of soil furnishes excellent grazing. In places where it was so wn several years ago it was found spreading all over the neighborhood, along the roadsides, ditch banks, and over neglected fields; at the same time it is easily subdued by cultivation, and does not in any way prove a pest to cultivated crops.

It will succeed if sown broadcast on old pastures, broom-sedges, etc., without any special preparation, and will soon spread and grow thickly all over the fields where put in, even taking the place of and driving out broom-sedges and wire grass. For sowing in woods that are used for grazing, or anywhere under the shades of trees, where other grasses do not succeed well. Japan Clover is to be where other grasses do not succeed well, Japan elover is to be shade than any other, as it succeeds and does better under denser it makes a dense green carpet, which is very attractive and desirable.

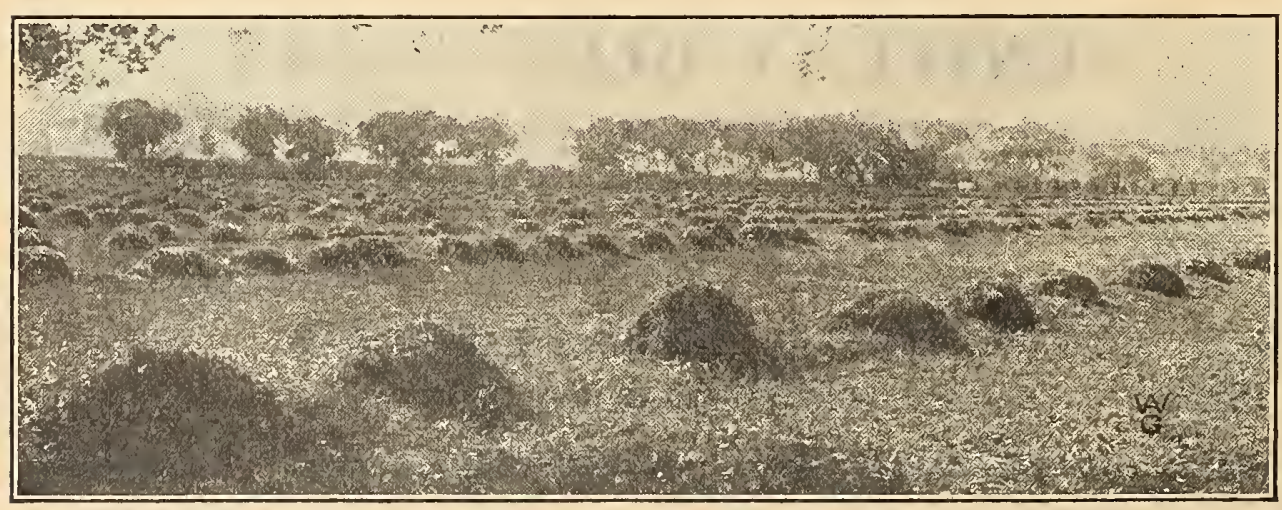

It is best not to graze Japan Clover too early the first scason, so as to give the seed time to mature and fall, which it is constantly doing all summer from the axil of the leaves. After the first season it can be grazed at any time. We do not recommend this clover for land that can be successfully grown in other grasses or clover in this section, but on waste land or poor. worn-out soils it will furnish excellent, nutritious pasturage. and at nutritious pasturage. and at the same time improve the con these poor lands to a conof these poor lands
siderable extent.

Sow at the rate of 10 to $\mathbf{1 5}$ lbs. per acre in MTarch or April. it does not make much showing the first year the seed is sown. Price, 60c per lb. Write for prices in larger quantities. 


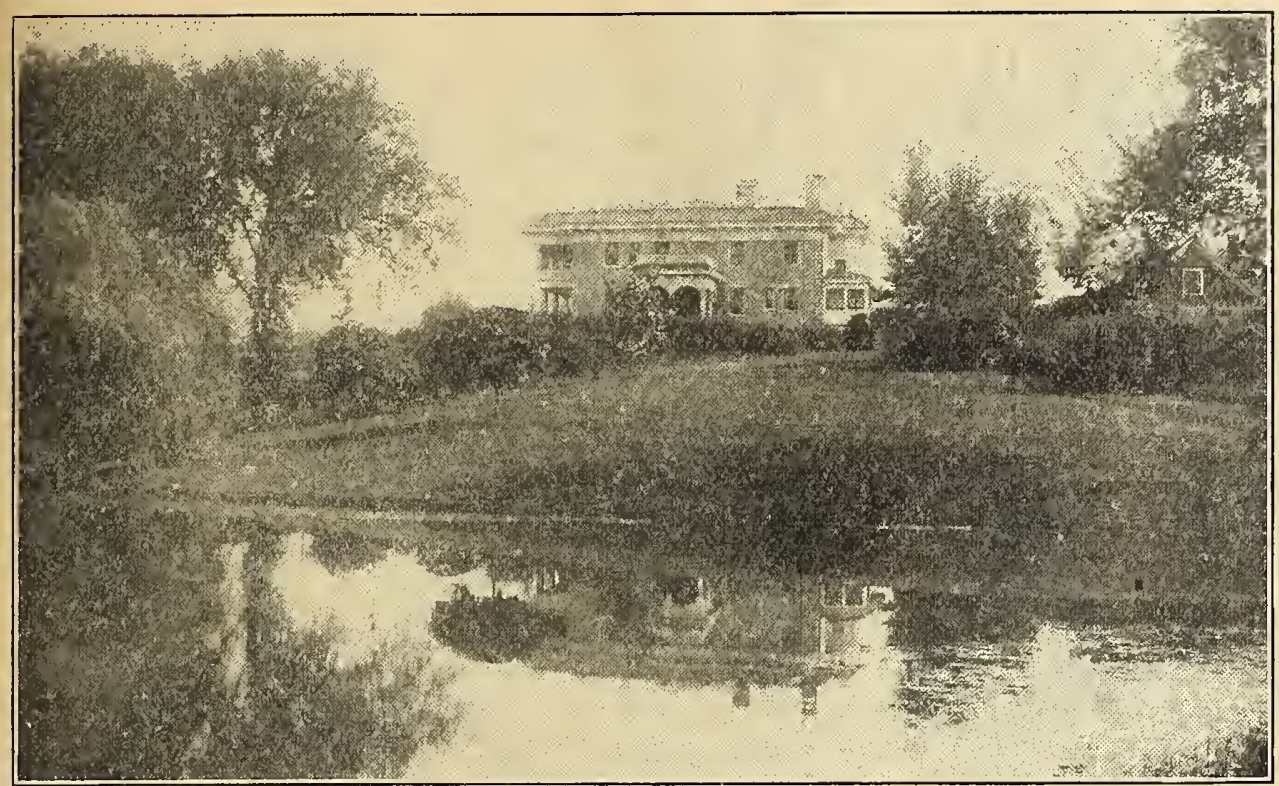

A beautiful lawn will add much to the attractiveness and value of your home
MARTIN'S

FL ORIDA

WINTER

\section{L $\mathbf{A} \mathbf{W} \mathbf{N}$ \\ MIXTURE}

This is a superb special mixture for winter lawns and is adapted only to Florida. If you will use this mi iture and give your lawn good care you will have one of the finest lawns possible to obtain Now is the time to start. Per lb., $75 \mathrm{c}$, postpaid

We have Special Lawn Grass Mixtures for Golf Courses, Country Clubs, Public Parks and Play Grounds. Write us for proves.

Our sperial lawn fertilizer sbould be used to obtain best results. Write us for prices.

\section{A W N S}

It is possible for the lawns in Florida to become famous as the most beautlful in the world. In few places can a new bome become so quickly surrounded with luxuriant vines, trees, shrubbery and flowers. More can be accomplishrd in this climate in one season than can be done in five seasons in tbe North. But, it of course, requires work and skill to keep up the beauty of a lawn. It is necessary to feed the grass well, as you can't expect it to remain beautiful after the elements of plant food have be' $n$ exhaustrid.

Lawns ran be made in Florida all the year. Tbe flrst thing to do in making a lawn is to put the soil in proper condition. Unevinniss in soil textıre and fortility produce unevenness in the growth and color of tbe lawn grass.

Lawns sliould not be clipped too short diring the hottest and driest montbs of tbe year. The knives of the machine should be set high and the short, fine clippings may be allowed to remain on tbe lawn, where they can work down around tbe grass plants and produce a mulch that will cons'rve moisture and protect the crown of the plants from extreme heat if the grass is allowed to grow too long before cutting and a large amount of clippings are produced, they are better raked off and taken away.

in new lawns weeds usually give trouble and verv often ln old ones For this we recommend only band weeding. as it seems to be the only reliable remedy. "eeds should be pulled roots and all as soon as they make tbeir appearance and are large enough to handle. They are more easily pulled from soft moist soil than from a bard dry surface.

\section{ITALIAN RYE GRASS}

Sow from 6 to 8 bushels per acre for lawns.

One of the most valuable grasses for fall planting, a quick grower, an annual, dying out tbe first summer. It is usid mostly in Florida as a lawn grass, and makes one of the quíck'st growths that can be plantid. It is generally sown ovir Bermuda or other lawn grass and will make a green lawn till spring. We are sclling a grtat quantity of this each season and the sale is steadily increasing. Bu., \$4.00.

\section{BERMUDA GRASS}

Sow for lawns 15 pounds per acre.

This is the most valuable lawn grass for Florida, as it is well adapted to light soils and in some sections is tbe only grass that will make a good sod on this class of soil. It also does wrll on clay and loamy soils. It is rather late to start in the spring, but stanrls hot, dry weather rrmarkably well, making a valuable summor lawn. Some gardeners prefer to mix a prretntage of Kentucky Blue Grass and white clover with Bermilda and f'snecially whrn a quick lawn disired, as the clover and the Kentucky Blue Grass will make a good green showing before the Bernuda grass is ready, but the Bermuda grass is to be depended on for a permanent summer lawn. Lb., 75c, postpald.

For winter lawns, ltalian rye is used. We sell carloads of Italian rye each season for Florida winter lawns. See description on this page.

\section{CLOVER SEED}

White.-Well known. It forms a thick, close turf, is excell'nt to sow for pastures, especially on sandy soils, and should enter into tbe composition of all lawn mixtures. Alone, it requires four to six pounds per acre: in mixture. from one to two pounds. Lb., 90c, postpald.

\section{KENTUCKY BLUE GRASS}

It is ratber sensitive to heat, but not so to cold weatber and on this account does its best in the fall, winter and spring. It grows slowly at first, forms a very compact turf. making a fine pasturage whon once estahlisbed. It is much the best, however, to combine other grasses with it for either lawn or pasturage. Sow in the spring or fall. Lb. 85 , postpald.

\section{F E R T I I Z E R S}

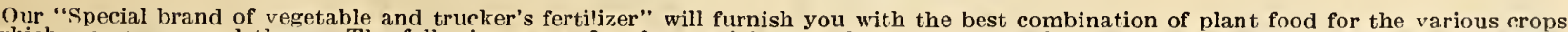

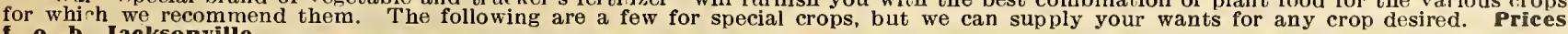
f. o. b. Jacksonville.

Vegetable Special, Cucumber Speclal, Irish Potato Special, Strawberry Speclal, Bean Speclal, Cabbage Speclal, Cantaloupe Special, Watermelon Special, Tomato Special, Sweet Potato Speclal, Speclal Corn-Grower.

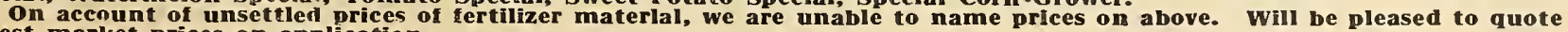
lowest market prices on application. 
It Sticks; It Stays; It Stimulates; It Saves

\section{BUG DEATH}

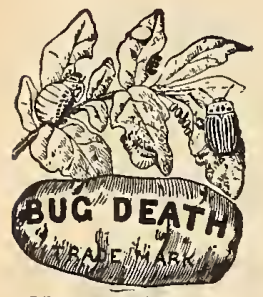

The INSECTICIDE which kills most bugs and worms that eat the leaver of nlants, trees and vine's: protects from injury by the flea heetle. is especially valualle for potato. tomato, squash and cucumber vines, currant and gooseberry bushes, strawherry plants. etc.: helns to ward of Blight, commonly known as Rust, on these vegetables and known as Rust, on these vegetables and berrips. saves beets from wormy leaves. celery from rust, asparagus from injury. cabhages and canliflowers from distruction. BUG DEATH is a fine powder whirh may safely be issed on all plants. trees and vinrs. as it CONTAINS NOPARIS GREEN OR ARSENIC IN ANY FOR II

In careful tests with lrish notatoes those on whirh BUG DEATH was applied yjelded $67 \quad 5 / 9$ hushels more per acre than those treated with Paris Green. At an average price of $5^{\prime \prime c}$ ner hishel this means $\$ 3378$ more por one acre,

6756 more for two acres,

168 9 more for five acres.

.

Consldering a pronortionate average increase of proft on other vegetables, can you afiord not to ise BUG DEATH? follows:

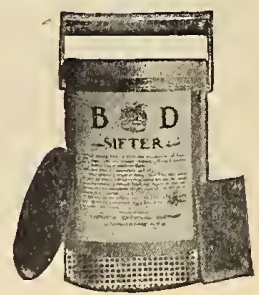

By Parcel Post-Prepaid 1st and 3rd 4th

1-lb roind carton (with sifter top). 3-lb. cart.nn.................. 5 -lb carton. 2 zones. zone. zone.

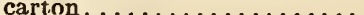
$121 / 2-1 h$. wooden box.

100-lb. Keg.

Acre-an-Hour

$\begin{array}{rrrr}.60 & .63 & .70 & .75 \\ .80 & .85 & .90 & 1.07 \\ 1.50 & 1.60 & 1.90 & 2.20 \\ 9.50 & \text { not prepaid } & & \\ 3 & .35 & .36 & .37\end{array}$

$\begin{array}{lllll} & .30 & .35 & .36 & .37 \\ & .80 & .86 & .88 & .91\end{array}$ (See Parrel Post Information, which will advise you the zone

Full directions for using. hnth dry and in water, on each package.

(ilve this nrelaration a trial and he convinced of its merits

THE ACRE-AN-HOUR SIFTER for one or two acres.

The Diamond Slot Bug Death Duster Por larga areas, 2-row hand nower, 4-row horse power. (Ask us for information.)

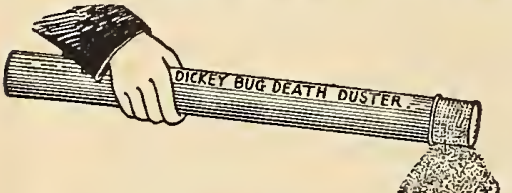

To apnly BUG DEATH in dry form, use

The Dickey Bug

Death Duster

For Small Gardens

It Sticks; It Stays; Kills Bugs; And Pays

\section{Corona Insecticides and Fungicides}

COMPOSED OF THESE STANDARD PRODUCTS.

"Corona Dry" will not burn or injure plants. shrubbery or trees. and is not easily washad off by rains or in watering. It is the same pure chemical compound that is used by commercial growers of fruit and vegetables throughout the country.

200-lb. drums

100-1b. drums
$50-1 b$. drums

25-lb. drums

Ask for

10-1b. packages.

5-lb. packages.

$\$ 5.00$

1/2-lb. package

.60

35

Corona Bordeaux Mixture (Dry) - A standard remedy for Fungous Pests. Ask for 10-1b. nackages....... $\$ 3.00$ 50-lb. drums $\}$ Prices 5-lh. nackages.......... 1.75 25-lb. drums

1-lb, package

$1-10$. package ......... . 40

Corona Dust 10-lb. packages. ..........\$1.50 1-1b. package......\$ .20 5-lb. packages. ........... $\$ .85 \quad 1 / 2-1 \mathrm{~b}$. package ........ .15

Corona Tobacco Duist.-Genuine Tobacco Dust, ground fine for use in the home garden. Full nicotine strength and free from sticks, grits, paper, nails, etc.

sicks, grits, paper, nails, etc. $\$ 1.50$ 1-lb. package .......\$ \$ 20

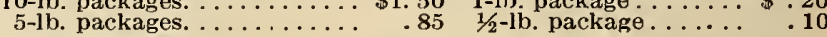

\section{HAMMOND'S SLUG SHOT}

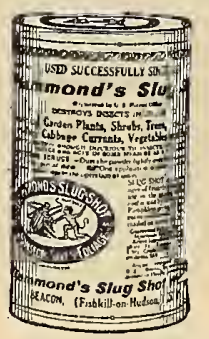

Used from Ocean to Ocean for 39 Years

SLUG SHOT is an Insecticide to destroy Potato slugs and Cabbage Worms on Cabhage and similar plants, and certain Worms on Currants. Tomatoes and Egg Plants: Flea Beetles, Striped Cucumber Beetles and similar leafeating Insects; certain Slugs and Caterpillars on trees and bushes.

SLUG SHOT kills many Injurious Insects without injury to the Foliage.

IF YOU WANT CABBAGE FREE FROM WORMS, USE HAMMOND'S SLUG SHOT.

How to Destroy Cabbage Worms. - Slug Shot can be used lightly or heavily and the cabbage suffers no harm. The cabbage forms its head by interior growth: it throws off its earlier and outside leaves, and no dust can enfold within its head. Apply Slug Shot with a duster (see illustration). sieve it over the plants or full in field or garden. $1 \mathrm{lb}$. can, $\left.35 \mathrm{c}^{\circ} 5 \mathrm{lb}, \mathrm{pkg} . \$ 1.5\right): 10 \mathrm{lb}, \mathrm{pkg}, \$ 2.75$.

The measure of success achieved by SPRAT'T"S DOG FOODS is the outcome of their intrinsic worth, every ingredient entering into their manufacture being chosen either as a health producer, a body builder or vitalizer.

\section{SPRATT'S CAKES}

\section{DOG \\ Pkg.: Price, 35c.}
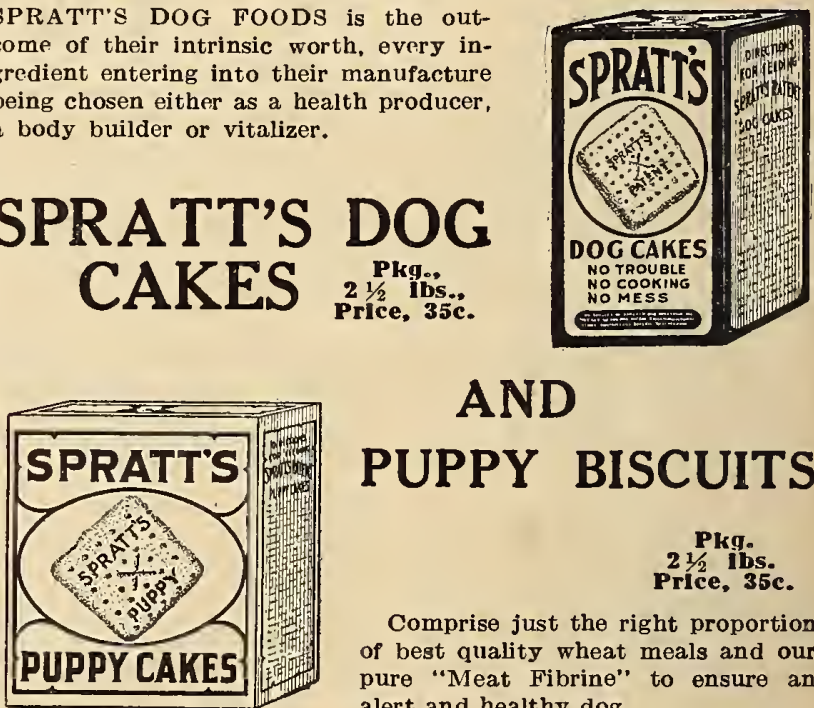

\section{AND \\ PUPPY BISCUITS \\ Pkg. \\ Price, 35c.}

Comprise just the right proportion of best quality wheat meals and our pure "Meat Fibrine" to ensure an alert and healthy dog.

\section{FLOWER POTS AND RED EARTHENWARE SPECIALTIES}

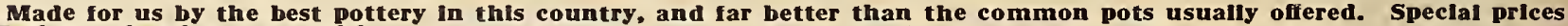
to forlsts using large quantities.

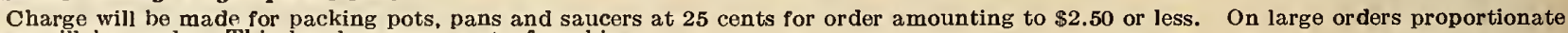
charge will be made. This barely covers cost of packing.

$\begin{array}{rrr} & \text { Standard Pots-Inside } & \text { Measurement. } \\ \text { Size } & \text { Each } & \text { Doz. } \\ \text { 2-inch } & 4 \mathrm{c} & \$ 0.40 \\ \text { 3-inch } & 5 \mathrm{c} & .50 \\ \text { 4-inch } & 9 \mathrm{c} & .75 \\ \text { 5-inch } & 10 \mathrm{c} & 1.00 \\ \text { 6-inch } & 11 \mathrm{c} & 1.25 \\ \text { 7-inch } & 14 \mathrm{c} & 1.50 \\ \text { 8--nch } & 23 \mathrm{c} & 250 \\ \text { 9-inch } & 28 \mathrm{c} & 3.50 \\ \text { 10-inch } & 50 \mathrm{c} & 5.00 \\ 12-\text { inch } & 75 \mathrm{c} & 7.00\end{array}$

$\begin{array}{rl}\text { Per } 100 & \text { Size } \\ \$ 2.50 & 61 / 4 \times 23 \text {-inch } \\ 3.50 & 8 \times 3 \text {-inch } \\ 5.00 & \\ 6.50 & \\ 8.00 & \\ 11.75 & \\ 14.00 & 1-q t . \\ 19.00 & 2 \text {-qt. } \\ 30.00 & 3-q t . \\ 46.00 & \text { 4-qt. }\end{array}$

\begin{tabular}{cr} 
Each & \\
$25 \mathrm{c}$ & Doz. \\
$30 \mathrm{c}$ & $\$ 2.25$ \\
\hline & $\mathbf{3 . 0 0}$
\end{tabular}

PIgeon Nests.

$\$ 20.00$

Per 100

Drinking Founts.

$35 \mathrm{c}$

$70 \mathrm{c}$ 


\section{$\square$ POUITRY:SUPPIIIS $\square$}

In the past ten years farm products have not increased in proportion to the population. with the consequence that their value has greatly increased. The high price of foeds has reduced the number of cattle fattened in the fecding districts, so that there is less of it being done now than at any time within the past ten years, notwithstanding the increased population.

The consequence is that all meat foods have doubled in price, and eggs, poultry and dairy products have had their share in the increase, and from the present indications will have more than their increase, and from the present indications will have more than their in the more thickly settled products can be grown on small rarms in the more thickly setticd parts of the country. and it is inevitabla that they should replace beef to a great extent. The prodicer of pect an increasing market that will become more and more profitpect

\section{Opportunities in the Poultry Business}

\section{RAISE POULTRY}

With poultry and eggs at exceedingly high prices

\section{Now is the Time}

To raise poultry either for just your own use or on a commercial scale.

\section{We will Help You Get Started}

\section{WRITE US} The poultry business presents larger opportunities than any other farin specialty, and, in fact, for thi amount of mont $y$
Invested, a greater profit than most mercantile and manufacturing industries afford. The various branches of the commercial

poultry business can be summed up as follows: to raise small birds for market during the off srason: the winter roaster busin'ss, wher" large roasting chick'ns and capons are produced at a time when there is a scarcity of fresh-killed chickens, and the duck business, where ducks only are raised for market purposes.

There ls no branch of the poultry business that presents less risk and surer gain, with quick returns, than the ege business. Its all-year-round income makes it the most popular branch of the noultry business.

We have a number of customers who raise stock chickens for sale or can furnish eggs.
We shall take plcasure in furnishing thelr names to anyone interested. We shall be glad to put any of our customers' names on this list who have chickens and eggs to offer.

DO YOU KNOW That the value of the eggs and poultry consumed in the United States every year exceeds that of

Every day ln the year there are about $125,000,000$ eggs used in this country, and the value of them and the poultry consumed, per annum, is computed to be $\$ 900,000,000$

Are you getting any of this?

The domestle egg supply is not equal to the demand. Millions of eggs are imported annually. If it pays to produce eggs
in foreign countries, pack and ship them to this country with added costs of freight, won't it pay YOU to produce them HERE?

There's always a market for both eggs and poultry. The question is

\section{How to Get Profitable Products}

It used to be a general assumption, and is so yet, to a certain extent, that after a man had made a failure of anything or everything else, he could make a success keeping chickens. Anyone can keep chickens, is the way they figure it. Quite true. but not every one can make the chickens keep them.

To make the poultry business pay, the first requisite is to keep your poultry in a healthy condition.

Don"t let your fowls get sick. That is our advice to you, and it is easy to follow,

How? First: Breed only from your hest, most vigorouts fowls.

Second: Set your eggs in properly constructed incubators, and raise the chlcks in well-ventilated, well-heated Brooders or Hovers. thereby avoiding the lice that young chicks start with when hatehed and raised with hens. This will give you a start with strong chicks. It's half the battle.

Chickens of whatever age require a ration containing feedstuffs of four different classes: Grains, Animal Food, Green Food and lineral .llatter.

These have been aptly called "Grains, Greens. Grubs and Grits." If any of these are omitted the results are bound to be more or less unsatisfictory.

Whlle this list may snem somewhat imposing, it is in reality simple, and a ration containing all four groups need cost no more than one which is incomplete

We carry a complete stock of the highest quality Grain, Feed, Grit and Shell, Beef Scraps, etc., which you will find descrlbed in this catalogue.

If you are a poultryman or stock-raiser and interested in prices, we will be pleased to add your name to our weekly price list, which we issue on grain, feeds, etc.

Mica Crystal Grit.-This Grit is prenarcd especially for poultry. Perfect material for hoth grinding and shell-making. W'e can supply this in sizes sultable for poultry, pigeons, ducks and small chickens. Grit is the chickens' teeth. and often means the difference betwenn success and failure with poultry.

Crushed Oyster Shell. - Splendid for poultry, to help in the formatlon of egg shells and keep fowls healthy. Use it freely. Feed alone.

Coarse and FIne Cracked Bone.-Consists of ground beef bone, thoroughly dried. lt is more economical and better in every way than common raw beef hone. Rich in bone phosphate of lime, which ls so necessary for making good egg shells and for building up the frame of the chicken. Should be placed in liberal quantities in the frame of the chicken. Should be placed in liberal quantities

clean, dry place, easily accessible to the chickens at all times.
Raw Bone Meal. It is made from fresh bone, from which the moisture has been taken. lraving nothing but the phosphates, lime and protcin. These are the only food propertles of bone, green lime and protrin. These are the only food propertles of bone, green or dry. This hone will keep in any climate or any kind of wrather Blood Meal. - Pure Blood Meal frd to your poultry will make your hens lay, your chicks grow fast, and keep your fowls healthy. Should be mixed with corn meal, bran or wet food.
Darling's Beef Scraps.-For success with poultry, lt is absolutely necissary to give them plenty of animal food in the winter to take the plare of insects, etc. For this purpose, Beef Scraps are one of the best foods that can be used. Feed mixed with mial or bran, at the rate of one-fourth pound of beef scraps per day to a dozen hens. We gilarantee the purity of our Beef Scraps. No pork or fat is used to add weight. It analyzes 55 per cent protcin.

Charcoal. - No poultryman can afford to be without rharcoal, and a little of it goes a long way. It aids digestion and promotes the hnalth of the poultry at all ages. It is prepared in three grades: Fine, for use in mash mixture: Medlum Granulated, for small chicks, and Coarse, for grown fowls.

Beef Meal. - Made from cooked beef scraps, thoroughly dried and ground It is isetter and more economical than fresh beef scraps. because it is concentrated and free from moisture.

Allalfa Meal-Very necessary for the laylng hen. It will insure a yreaier number of eggs, also a larger profiortion of $f$ rtlle ones. Alfalfa is also used to keep laying and breeding fowls in good health, and adds to the luster of the fowl's plumage. 


\section{Price List of Poultry Feed-Prices on Application}

GRAIN, FEED, ETC.

W. C. Oats, Cholce........ 100 lb hags Mixed Corn............ 100 lb. bags Best Wheat............100 lb. bags Best Wheat Bran. . (Best) ................... 100 lb. bags Feed Meal (Corn Hearts) $\ldots 100$ lb. bags Bright C. S. Meal, $71 / 2 \%$ Ammonla

Alfa Ifa Alfarfa Meal (Stock Feed) ... 100 lb. bags Alfalia Meal, Pea Green for

Poultry Mash ........... Ino Ih, hags Feed $C$. $\mathbf{S}$. Meal...........
Calf Meal. ........... $50 \mathrm{lb}$ bigs Call Meal. ...............

\section{POULTRY FEED}

Blue Ribbon Scrateh Feed... 100 lb. bags Blue Ribbon Developling Feed intermedlate Scrateh). . $100 \mathrm{lb}$. bags Blue Ribbon Chick Feed (None

Betteri... lin) lb. bags

Blue RIbbon Growing Mash. $100 \mathrm{lb}$ bags Blue Ribbon Laying vash. 100 ib hags
Purina Scratch Feed ..... 1no lb. bag Purina Chlrken Chowder .. lu lu lb. hags Cracked Corn, Sitted ... lut lb bay Corn Meai, Water Ground.. 92 lb. bags Ground white oats........ 100 Ib. bags Crushed white oats........ 100 lb. hags PIn Head Oats. ........ ino ib. hags Pin Head Oats, 5 lb. packiages $25 \mathrm{c} \mathrm{pkg}$ LInseed Meal ............100 lb. bags Beef Scraps, $55 \%$ Protein

Beef Scraps, $55 \%$

Proteraps, $55 \%$

We Issue a Weekly Prlce List of Poultry Feeds, Supplles, etc., and shall be pleased to add your name to our malliag list il you wiil advise us.

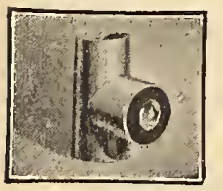

\section{STANDARD EGG TESTER}

A standard tester is shipped free with each machine This tester gives a strong. reflected light. and when used in a dark room illuminates the interior of the egg sufficiently for practical Work.

By mail.

\section{NAPHTHALENE NEST EGG}

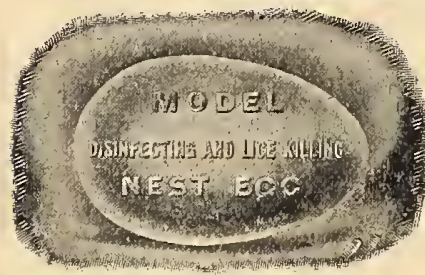

This Nest Egg is usrd, not in reality as a Nest Egg. but is put into the nest to remove and kill the lice-the same as a camphor ball is packed in clothing to keep out the moths. lo one of these Nest Eggs is placed in a nest with remove all vermin, if put in a comove all vermin, if put in a nestlng material a setting hen can remain on the nest with comfort and 'atch chickins instead of lice and mites.

lnlike those made of plaster of paris or other similar materials. it retains its disinfecting and lice-killing qualities as long as there is anything left. Price, 5c each; 50c per doz.; postpald, 5c each extra.

\section{PORCELAIN NEST EGG}

This article does not need any descrituton as it is well known to all who keep poultry. They are made of a good quality of flint glass and will last indeflnitely.

Price, each, 6c: per dozen, 60c.

\section{MOE'S SELF=LOCKING LEG BANDS}

A sealed band that requires no sealer. Lorked simply by pushing it together. ade of a brisht ninkel-colored metal that will not rust or corrode anufactured in eisht sises. Numbered consecuti elv …'h nmh sew Hors from 1 to 5.000.
MOE'S SELF LOCKINC BAND REATY'TO BE USED

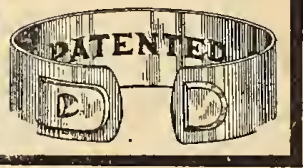

When ordcring please state what you are going to use bands on and we will send you proper size.

12 bands, any sire.

25 bands any size........... 30 100 bands any size $\ldots \ldots . \quad .85$ 500 bands. any size $\ldots . . . .3 .75$ 1000 bands. any size....... 6.50 50 hands ally sime. .50

\section{MOE'S KEY RING CELLULOID LEG BAND}

Made of celluloid in six sizes and ten colors. They are snapped on the bird without difficulty and make idintiflcation readily disc rnible.

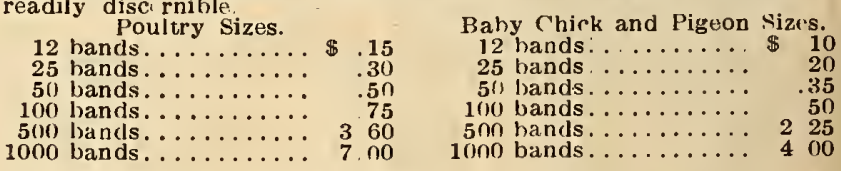

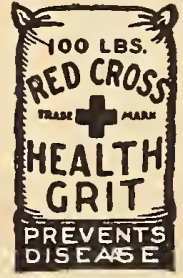

\section{RED CROSS XX HEALTH GRIT AMERICA'S GREATEST HEALTH GRIT MIXTURE \\ ONCE USED ALWAYS USED \\ MAKES PLUMP SQUABS. WHITE MEAT MATURE SOONER, PROLIFIC BREEDERS \\ PREVENTS \\ DISEASE}

No more dlarrhoea, no more golng IIght, no more roup-because It makes RIch Red Blood "IT'S GOOD FOR ANYTHING THAT WEARS FEATHERS."

All birds relish it. Contains in condensed form the best tissuebuilding ingredients for birds known to science, and the greatest amount of gritty matter. Leading pigeon and poultry fanciers every where claim It to be the only scirntifically pre pir r ll lialth
Grit on the market. Packed in I(w-1)ond hags The serial number 16045 is on every bag. and the Red Cross.
In ton iots.

1-2 ton.

1-4 ton

100-pound bag

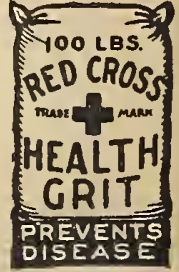

$\$ 4000$ 2100 11. 00 225

\section{B L UE RIB B ON POULTRY FEEDS}

\section{FLORIDA'S BEST KNOWN AND MOST POPULAR POULTRY FEEDS}

BLUE RIBBON LAYING MASH A Great Egg Producer. $2(1-22 \%$ Protein.

BLUE RIBBON SCRATCH FEED All clean grain. Eight different kinds properly balanced

BLUE RIBBON PIGEON FEED A perfect mixture. Grows big squabs.

BLUE RIBBON LITTLE CHICK FEED

The Ideal Chick Starter. Grows Strong. Sturdy Chicks.

A FEED FOR EVERY

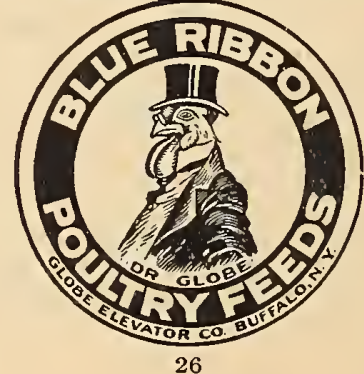

BLUE RIBBON DEVELOPING FEED For chicks four to eight weeks old. Feed it

BLUE RIBBON GROWING MASH Quickly assinilated. Insures even ftath'ring.

We have recommendid and sold these peeds for several siasons. "le sill more every y'ar. Our customers like them and come back for more. Insire your sucess in raising poultry by using Blue Ribbon Feeds. 


\section{HAVE A CONKEY CORNER IN YOUR POULTRY HOUSE}

And Be Ready when Dlsease Appears.

A healthy hen cannot krep from laying: by having CONKEY'S REMEDIES AND TON. ICS always at hand. be ready to $\mathrm{ight}$ the trouble just as soon as it appears.

Check over the following list and send us your order. Every moultry own'r should have on his poultry insurance you fan get.

Conkey's Roup Remedy is a $\quad$ Conkey's Poultry Conditioner is a
ientifically prepared medicine. Coming in contact with the membranes of the off fecd, recovering from disease, during throat and mouth, the seat of the disrase, molting scason or when preparing for the it kills the germs. $1 \mathrm{t}$ ls quickly taken show room. It is a general invigorator. up by the system and being a strong up by the systron blood. builds up the system and assists blood, buids up the system and assists off the disease. Price $30 \mathrm{c}, 60 \mathrm{c}$ and $\$ \mathbf{1 . 1 5}$

Conkey's Roup Plils. - For the individual treatment of hirds and for use in the show room Prlee, 30c, 60e and $\$ 1.15$.

Conkey's Canker Special.-A new remedy that effectively reduces the cankerous growth and brings the hlrd back to normal without a hlemish. Also fine for treating colds, etc Price, 60c.

Conkey's Sorehead Remedy._This disease is known by dilperent names in different localitles, such as Sore Head Pox Is very contagious. and is a very annoxing and disglusting discase. a very anto run. it leads to wcakness and death.

Symptoms.-Scabhy warts on the comb, lohes and face. Prire, 30c and 60c Conkey's Poultry Tonic is the resilt of years of careful stidy and experiment to the hirds. It kiens the howels in good condition. asslsts digestlon and the assimilation of egg-producing and strength-making materlal gives vigor to the fowls

Conkey's Pollttry Tonic is not a food in ltself, and in lts 11 se vo!l escape naying for hran and middlings which comprise the bulk of Inferior "egg producers." Prlce. 30c, 60c.

Conkey's Limberneck Remedy.limberneck ptomaine cholera poisoning is a very fatal disease, requiring immediat treatment. It can be easily cured in all early stages. Prine, pkq.. 60c.

Conkey's Cholera Remedy - We have put out this remedy in sueh a form that lt must be given in the drinking water. Prlce. $30 \mathrm{c}$ and $60 \mathrm{c}$.

Conkey's Bronchitls Remedy.-Bronchitis and Roup are frequently confised but they are separate diseases and requir. snecial treatment. It ls an inflammation of the memhranes of the hronchial tuhes: instead of the membranes of the nostrils and head nassages. Price, 60c

Conkey's Scaly Leo Remedy.-Scaly Leg ls raused hy a parasite working in and inderneath the scales of the feet and legs Price, 606 .

Conkey's Rheumatlc Remedy cures those lame and useless birds tones th system, limbers up the joints and gets them into profit-paying condition in very short order. It ls absolutely dependable if used according to dircetions. Prire, 60c.

reliable remedy for this annoying and deadl disease. It is gllaranteed to do the wor and to satisfy YOI. Prire, 30c and 60c. Conkey's Buttermilk Starting Food Starting Food will put vim and vigor into vour baby chicks at the time they necd it most. It will make them strong and hilsky, so that they can fight off most of the chick diseases that earry off so large a percentage of the yearly hatch Conkey's Buttermilk starting Food is a perfeetly halanced ration for baby chicks to he fed over the critical first several weeks. It contains clean, whole some grain and is mixed with pure butter-
milk hronght to a semi-solid state. This milk hronght to a semi-solid state. This combination is then dried so that th milk After the eighth week use Conkey' Buttermilk Mish.

$$
\text { Prices sublect to change }
$$

Price, 30c

Conkey's Lice Powder ls absolutely armless to the fowl, and positively overcomes the lice. Dust the fowls thoroughly every ten days, or two weeks, particularly after the old lice arc killed. Also use it in the dust bath. Prlce, 30c, 60c, \$1.15 Conkey's White Dlarrhea Remedy. When this disease prevails it usually kills a large percentage, sometimes destroying an nasty, fecal discharge, which pastes $\mathrm{up}$ the
frathers and closes the vent. Price, 30c and $60 \mathrm{c}$

Conkey's Head Lice Olntment.This article will destroy the head louse
which annually kills thousands of little annually kills thousar

Conkey's Poultry Worm Remedy. This is a most necessary artielus, as it aids in ridding the fowl of harmfil as will as other worms, promoting the return of healthful ditlon. Price, 60c.

Conkey's Nox-l-clde, - (Formorly called Taroline). This is the ponltrymen's poultry diseases may be traced to the presence of germs, which thrive unless a soluble disinfectant, deodorant and germ destroyer is used. Conkey's Nox-i-cidr
mixes with water, in correct proportion for using. one gallon making 101 gallons of ready-to-t1se liquid. It is the cheapest and mosteffective article of its kind ever put ont. For poultry, it is an unexcellrd article for cleaning and purifying the houses, runs, brooders. founts and utensils. For household 'ise it is of wond'rful value in almost evcry
department. It is unequaled for the sick room and for purifying everything about

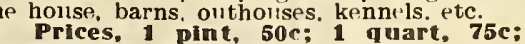
2 quarts, $\$ 1.25 ; 4$ quarts, $\$ 2.00$.

Conkey"s Fly Knomer.-Niany infections and dangerons discases are comminicated by fie's and other pests. to man beast and fowl. Conkry's Fly Knneker makes it possible for you to ov'r-
come such insects. Spray it on your stock and come such insects. Spray it on your stock and that your stock is far more profitahle and vour own comfort will be greatly incrrasid
ife guarantee it to give satisfaction. Prire, Conkey's Suiphur Candies. - For fumigation. 15c: 3 for $35 \mathrm{c}$.

Every Conkey Remedy is guaranteed to give satisfaction or money back. Send 5 cerits for Conkey's Poultry poultry diseases.

Conkey"s Poultry Tonic.-Contains no cayenne pepper. It is a laying tonic. and is prepared with the samc care that has made the effeiency of Conkey Polltry Remrdies world famous. A little in the ficd of rdies world famous. A little in the ficd of and strength in the hatching eggs. You can give Conkey's Poultry
Tonic to every hird in your fock every day in the year. It will pay you well to hrip your birds.

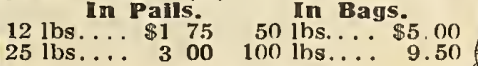
$\begin{array}{ll}1 & 1 / 2 \\ 3 & 1 b s \\ 1 & l b s\end{array}$ 1 quart, 75r: 2 quarts, 12.25 ; q qts., $\$ 2.00$.
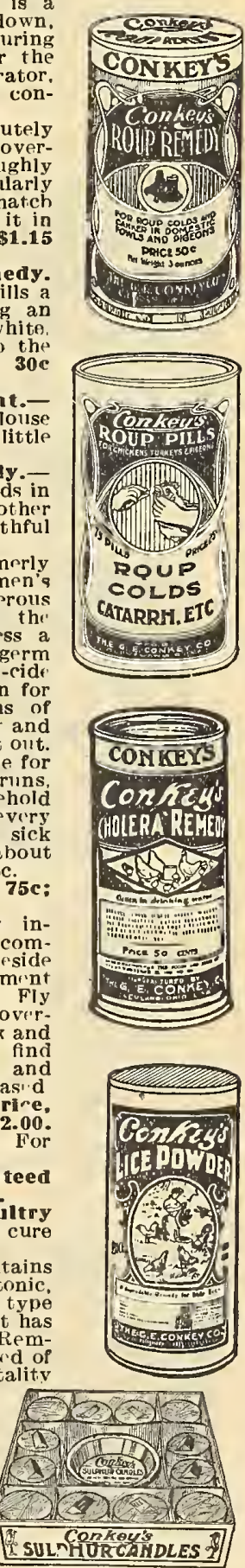


\section{Pratts Poultry and Stock
Regulators and Remedies
Baby Chick Food}
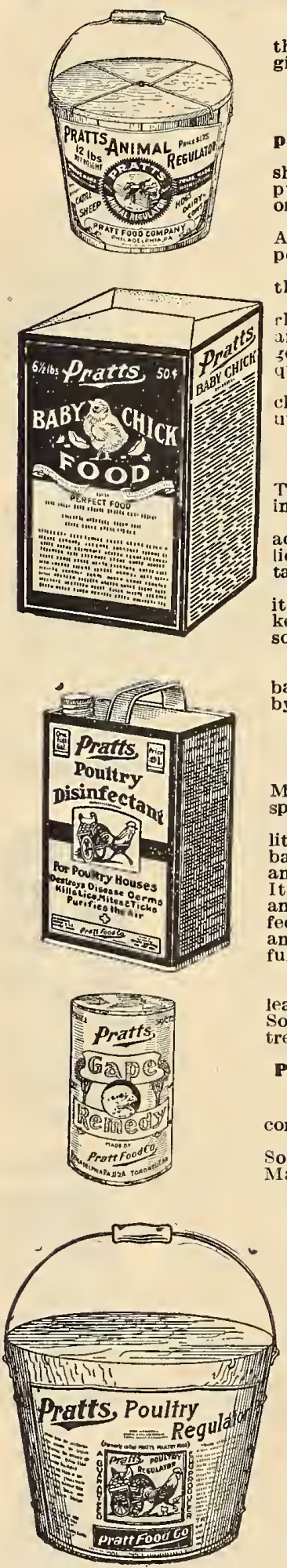

Healthy birds and lots of eggs, the two blg giving

PRATT'S POULTRY REGULATOR

12 lb. palls, \$1.75; 25 Ib. palls, \$3.00; packages, $60 \mathrm{c}$ and $30 \mathrm{c}$

It builds up vitality, insures sound digestion, sharpens appetite and prevents disease, thus putting hirds in condition for heavy egg laying or winning blue ribbons.

Pratt's is the original Poultry Regulator of America and is in use by the most successful poultry raisers every where.

When regularly used, hens lay throughout the year.

It will prevent chicken cholera, gapes, roup, rheumatism, expel worms, prevent leg weakness and egg eating. It will greatly lmprove turkeys, seese, ducks, pigeons and guineas-insuring
quick growth and keep them free from disease.

if poultry keepers would regularly spray the chicken houses, roosts, droppings boards and utensils with

\section{PRATT'S POULTRY DISINFECTANT}

most all of thelr troubles would vanish. This great disinfectant is a real wonder-worker in the poultry yard.

Three times as powerful as crude carbolic
acid. A sure deodorizer, germicide and liquid lice killer. Use it for roup, colds and other contagious diseases.

We want you to notice the price, making it the lowe'st priced disinfectant on the marsold for $\$ 1.50$ per gallon.

Half gallon, \$1.00: quart, 60c.

Get rid of lice on your poultry, in nests, dustbaths, incubators and elsewhere in a day's time by using

\section{PRATT'S POWDERED LICE KILLER} 60c and $30 \mathrm{c}$

Effectlve, non-poisonous, non-irrltatin May be used wherever a powder is suitable. A splendid deodorizer.

lt quickly and thoroughly kills all llce on little chicks, big chicks, setting hens and lncubator chicks. It rids horses, cattle, hogs, dogs and cats of llce and destroys ticks on sheep. It destroys insects and bugs on vines, plants and fowers. A valuable deodorizer and disin fectant for all poultry houses, barns, stables and dwellings. Drives out moths from closets. and dwellings. Drives out moth

lailed postpaid upon receipt of price.

From gratifying experience poultry men have learned that the disgusting disease known as Sore Head or Chicken Pox can be successfully treated with

\section{PRATT'S SORE HEAD (CHICKEN POX)} REMEDY $-60 \mathrm{c}$ and $30 \mathrm{c}$.

It acts quickly, checking the spread of the contagion and curing the sores. Sore Head (Chicken Pox) Remedy is used.

Sore Head (Chicken Pox) Remedy is used.

Don't let Roup cut your profits. The sure

and easy "ounce of prevention" against

PRATT'S ROUP REMEDY

Tablets or Powder, 60c, 30c.

Quickly absorbed by the blood, purlftes

the system, reduces fever, allays inflammation. The safe remedy for roup, colds, catarrh and all bad weather diseases.

Mailed postpaid upon receipt of price. healthy and growing and bring even the weak ones along by feeding

\section{PRATT'S BABY CHICK FOOD}

14 lbs. Ior \$1.50; packages, 60c and 30c. baby chicks. Guaranteed to raise every livable chick. Costs a cent a chick for three weeks. Prevents leg weakness, whlte diarrhoea, "pasting up" and other chick diseases.

To protect your chicks from white diarrhoea, the most destructive of all chick diseases, it is only necessary to gRATT'S WHITE DIARRHOEA REMEDY

60c and 30c.

in the drinking water from the flrst drink. This remedy has saved many dollars' worth of chicks for poultry raisers. You can depend on it.

Mailed postpaid on receivt of price.

Head lice causes the death of thousands of baby chicks every season. You can save these chicks if you will apply

\section{PRATT'S HEAD LICE OINTMENT} 30c.

An unfailing and guaranteed remedy for gapes, one which acts quickly and causes the worms to be expelled.

\section{PRATT'S GAPE REMEDY} 60c and 30c.

If used in the drlnklng water from the start until the chicks are four weeks old, gapes will be practically unknown and it will effect a positive cure in chicks already attacked.

Mailed postpaid on receipt of price, poultry than chicken cholera, An unfailing remedy is

\section{PRATT'S CHOLERA REMEDY} 60c and 30c.

It is administered in the drlnking water and will be found equally valuable for treating all digestive troubles such as sour crop, dysentery or diarrhoea.

Mailed postpaid on receipt of price.

More work out of your horses, more milk from your cows, patter hogs - thise are a few of the benefls which come with uslng

\section{PRAT'T'S ANIMAL REGULATOR}

Costs less than a cent a day per horse or cow.

This is the original and ploneer stock regulator of A merica. Tested thoroughly for nearly nalf a century, its worth ls known and recognized by stock owners the world over. Always sold in a uarantee that will satisfy you or money back.

\section{Packages, 60c and $30 \mathrm{c}$.}

Give comfort to horses, cows and all other live stock in tyy time by spraying them with

\section{PRATT'S FLY CHASER}

We guarantee it to be unapproached as a fly repellant. It has long effleiency, will not blister, remove the hair or damage the hide. Insures comport at milking tlme for the cow and safety cor the milker. Does not taint the milk or gum for the milker. Does not taint the milk or gum the hair Soothing and healing on bites and sores. Has no Injurious acids. Economical. noultry lice killer. 1 gal., \$1.50; half gal., 90c.

Pratt's Worm Powder, 60c and \$1.25.

Pratt's Veterinary Liniment, 30c, 60c and $\$ 1.20$.

Pratt's Cow Remedy. Packages 60c and \$1.20: 12 Ib. pall, $\$ 2.50 ; 25$ Ib. pall, $\$ 5.00$.

Pratt's Bag Dintment, $35 \mathrm{c}$ and $70 \mathrm{c}$.

Pratt's Healing Olntment. $30 \mathrm{c}$ and $60 \mathrm{c}$.

Pratt's Animal DIp. 1 qt., 60c; 2 qts., \$1.15; 1 gal., \$1.75.

Pratt's Distemper and PInk Eye Remedy. $75 \mathrm{c}$.

Pratt's Veterinary Collc Remedy, 75c and $\$ 1.50$.

Pratt's Heave, Cough and Cold Cure, $60 \mathrm{c}$ and $\$ 1.25$.

PRICES SUBJECT TO CHANGE

\section{SATISFACTION GUARANTEED OR MONEY REFUNDED}
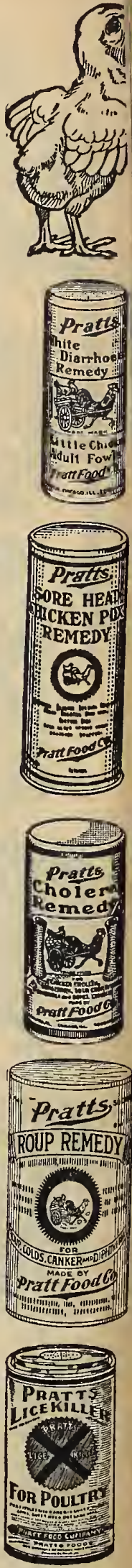

IMPORTANT.-Add 2c for war tax on each 30c package of Poultry Remedy; 4c for 60e package. 


\section{Fixtures for Poultry Houses and Yards}

\section{Some New, Handy Sanitary Articles to Help You Make the Chicks Thrive and Grow}

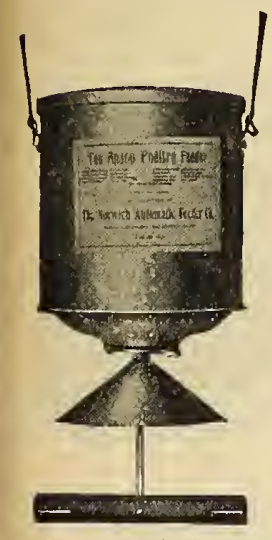

PAIENTED maY O. ISU

\section{The Apaco Poultry Feeder}

Same mechanical features which have proven so successfui in the Norwich Auto matic, but of the hanging type. Designed for the smail breeder or "backyarder," but not recommended for the commercial piant owing to swaying motion, present in all hanging feeders, if kept constantiy in action by larger flocks. Rotary action. compiete with the all-important adjustable valve for regulating feed discharge, and guaranteed the best automatic feeder on the market at its price.

PRICE

Made In one size only, 12 quarts capacity................. \$2.25 Shipping weight, 5 lbs.

THE NORWICH CHICK FEEDER

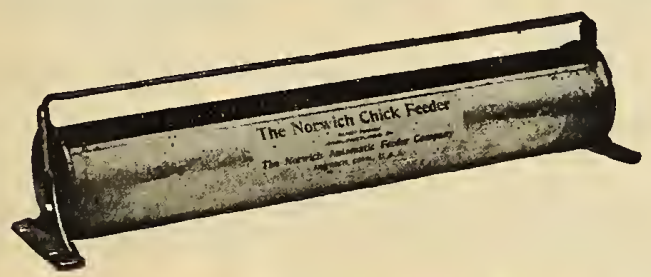

Positively prevents chicks from wasting the-mash, and it is impossible for them to get into the feed, thus making it an absoluteiy sanitary feeder. Top rod removable for flling and cleaning. Ends riveted and burred to brackets. The strongest and best Chick Feeder ever piaced on the market. Perfection as a sour milk feeder.

PRICE LIST.

Made in three sizes.

10-inch. Shipping weight, 15 ozs............... 45c

15-inch. Shipping weight, 19 ozs $\ldots \ldots \ldots \ldots \ldots \ldots \ldots \ldots \ldots \ldots \ldots$ s0c

20-inch. Shipping weight. 23 ozs................ 65e With Rain Top, add 12 cents to list and 7 ozs. to weight.

\section{SANITARY FEEDING TROUGHS}

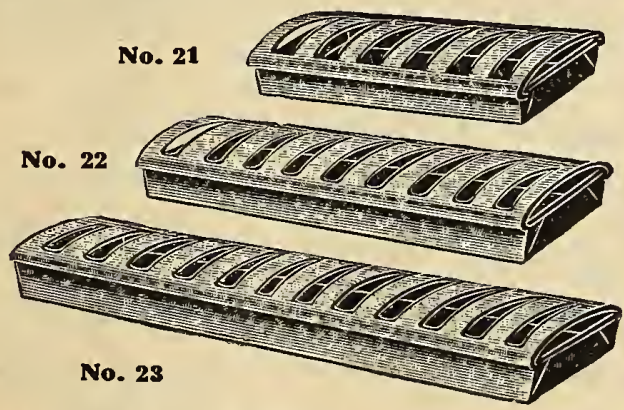

Can he used for feed, wet mash or water.

Barred top prevents wasting of peed, and if used for water does away with the little chicks drowning. The feed saved by using this trough will more than pay for itself in a few weeks. Made of the best grade of galvanized iron in three sizes, nameiy:

No. $21-12$ inches long, each...................... 60

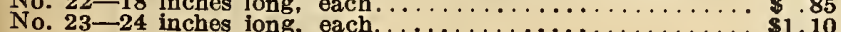

MOE'S ROUND BABY CHICK FEEDER

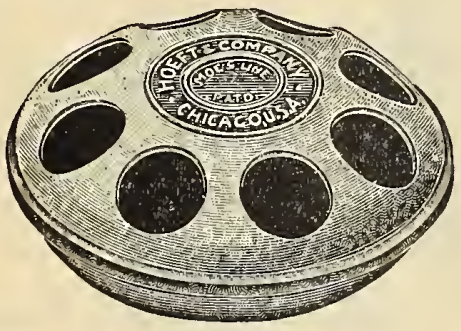

Moe's No. 11 Feeder.
Pure food for the baby chicks. A great feed saver. as the little chicks cannot get into it and contaminate the feed. Cannct be upset. Can also be used for water or milk. This is a practical. well-made fecding derice that will last. for years. Mlanufactured in two sizes.

No. $11-6$, inches in

diameter. 8 fceding

holes, each

No. $1281 / 2$ inches

in diameter, 12

.40

\section{CHICK GRIT AND SHELL BOX}

Growing chicks should have grit, oyster sheil and charcoal al ways before them: and for this purpose our Chick Grit and Shell Box is indispensable.

It is made of galvanized steel, with three compartments.

Height, $71 / 2$ inches; width, 6 inches: depth (Pront to hack), 4 inches at bott om and 2 inches at top.

Price..........60c; hen slze, $\$ 1.25$ shipping weight, 2 ibs.

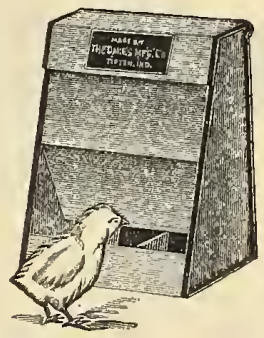

\section{CAPONIZING SET}

Increased interest in caponizing has ied us to have prepared for us, by one of the lrading Instrumnnt makirs of this country, this sperial set of caponizing tools, which are designed after the most approved models. Capouizing ls easy to learn, and all surpius cockerels should be operated upon, as the hirds then grow faster and fatten more quickly with less food. Full directions are furnished with this set, so that good results may be obtained by the amateur. Price, complete, \$3.25, postpald.

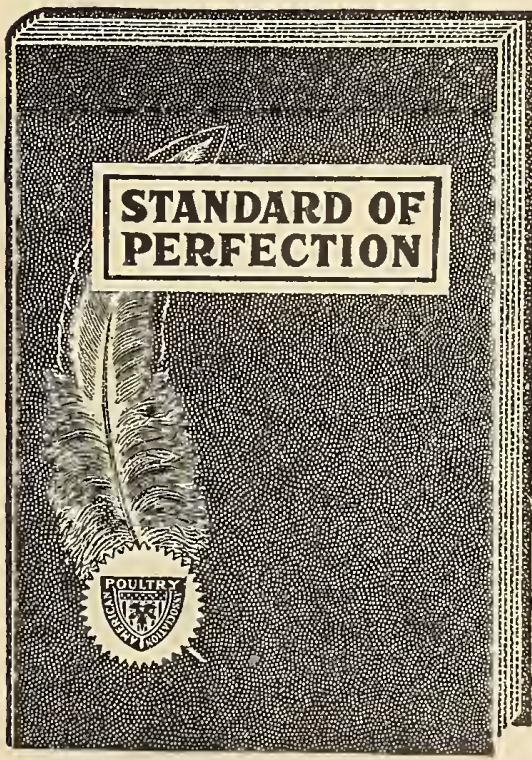

The New Bevised and Enlarged Standard of Perfection

The Only Recoginized Anthority On All Standard Requiremen

Handsome cloth hound book of 368 pages. 112 full page illustratlons of pouitry, hantams, ducks, guese and turkeys.

A new nomenclature Indicating nach section iff all Standard section and varietios male and female remale. A glossary of freen pagns describing and liustrating many technical terms used by poultry hreeders. A complete list of recognized disqualiflcations for each American stand. ard-hred breed and variety. A chapter on cutting for diferts. No pouitry breeder shouid be without a copy.

Bily a copy and know the standard requlrements for all American standard-hred hreeds cloth, \$2.00, postpaid. 


\section{E.A. MARTIN SEED COMPANY, JACKSONVILLE, FLORIDA}

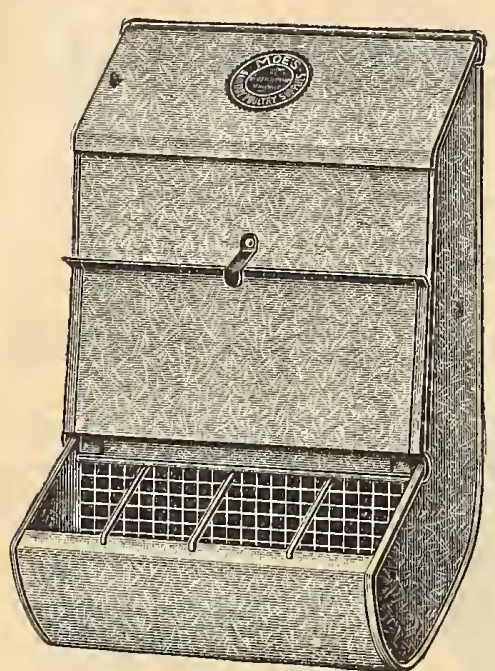

\section{DRY MASH HOPPERS}

Large in capacity and small in price.

Does away with all trouble of feed logging, no matter how coarse. The sradual enlargement to the base tosether with the vibration of the fowls feeding from the trough will force the feed down ward. It is a great feed saver. Every safeguard has been placed in the :onstruction of the trough to prevent he birds from throwing out the feed. A rial will convince you that it is a hopper if the greatest merit. Manufactured of leavy galvanized iron in three sizes.

vo. $35-81 / 2$ in. wide, 12-quart capacity, each ................. \$1.50 vo. $36-12$ in. wide, 18-quart capacity. each.................. $\$ 200$ No. $37-24$ in. wide, 36-quart capacity. each

\section{Raise More Poultry and Live Stock}

\section{Plant More Food and Feed Stuffs}

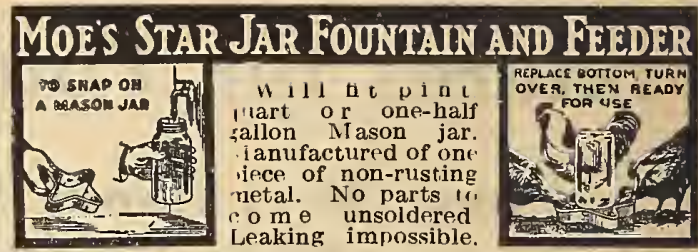

Convenicnt. cheap and sanitary. Pruvides gre.ter drinking surface th $\mathrm{n}$ the round fountain. Little chick cann $t \mathrm{~g} t$ drowned. Can be used for feed as well as water. Manufacturid in one size only

\section{Rectangular Chick Feed Hopper}

This hopper is designen for young chicks, and mad to either stand on the floo or ground, or hang agains! three equal compartments holding about four quart: holding about four quart: altogether. Made of galto both hopper and trough

Price.........\$1.35 eacl Shipping weight, $3 \frac{1}{2} \mathrm{lbs}$.

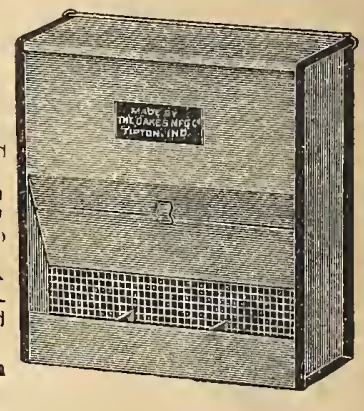

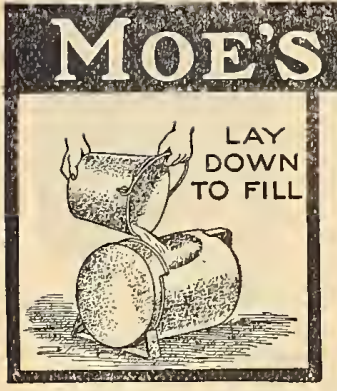
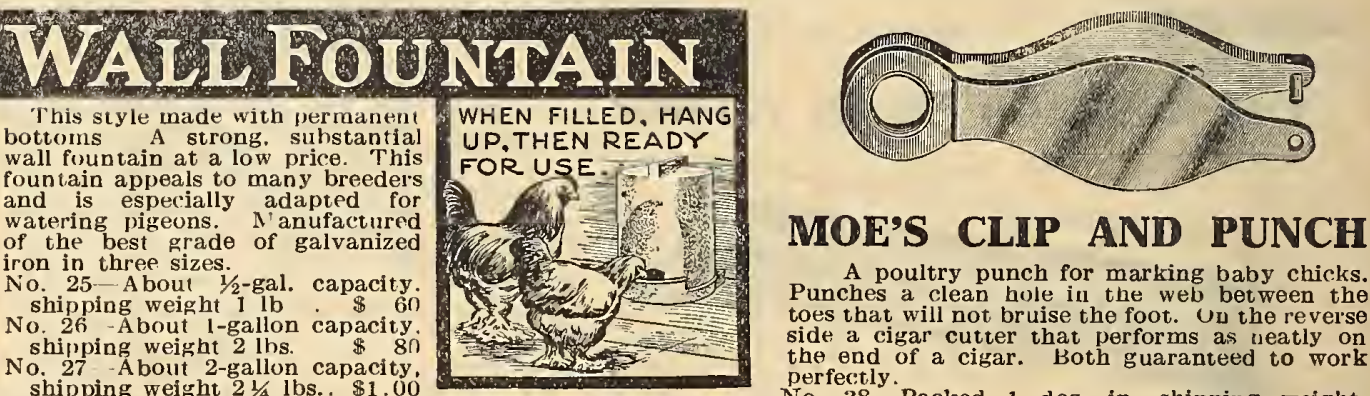

A poultry punch for marking baby chicks. Punches a clean hole in the web between the toes that will not bruise the foot. UD the reverse side a cigar cutter that performs as ueatly on the end of a cigar. Both guaranteed to work

perfectly. -Packed 1 doz. in. shipping weight. per doz., $5 \mathrm{oz} . . . \ldots . . . . . . . \% \$ 25$

\section{BOTTOM FILL FOUNTAINS}

A General Utility Fountainn at a Low Price.

Made in two pieces. Easily cleaned and owing to its shape it will not burst from freezing. This fountain fills the breeder's necds for an inexpensive fountain. Made of the best grade of galvanized iron in three sizes.

Size

No. 19-About 1-qt. capacity, No. 20 -About $1 / 2$-qal. capacity, No. 24-About 1-gal. capacity,
Packed Shipping Wt. Price 2 doz. in $18 \mathrm{lbs} .$. each $\$ .40$ 2 doz. in $25 \mathrm{lbs} .$. each .50 $1 \mathrm{doz}$. in $16 \mathrm{lbs}$... each 1.00
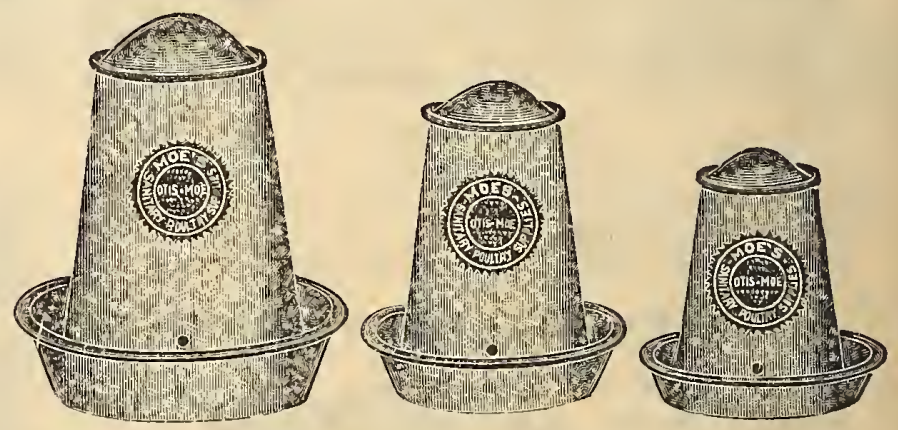

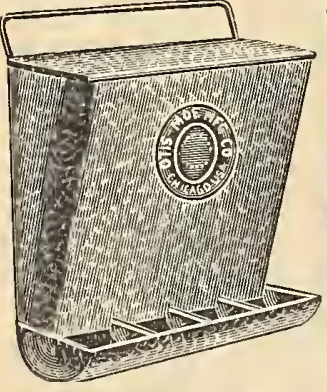

No. 90-Four-compartment, round bottom.

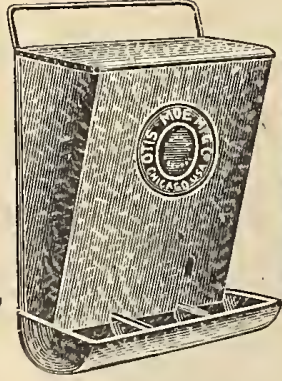

No. 9-Three-compartment, roumd bottom

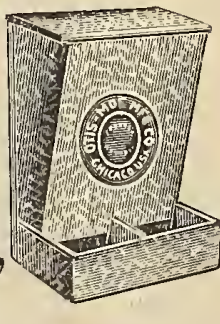

No. 45-Twocompartment square bottom

\section{GRIT AND SHELL BOXES}

Grit, shell and charcoal have now become a recognized essential part of the diet. lnsuring bealthy fowls. They cannot oe more economically supplied than in one of our inexpensive compartment boxes. Can also be used as a feed hopper for little chicks. Made of heavy galvanized iron in three sizes:

No. 45 - For baby chicks. each $\ldots \ldots \ldots \ldots \ldots \ldots \ldots \ldots \ldots \ldots \$ .45$

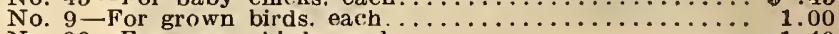

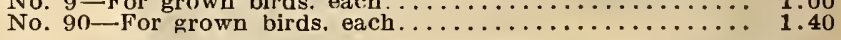

\section{POULTRY WIRE FENCING}

\section{WE CARRY A COMPLETE LINE} WRITE US 


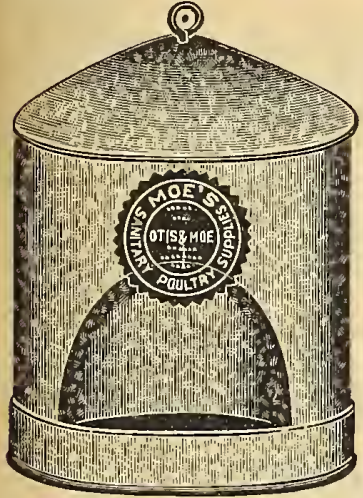

\section{MOE'S BROODER FOUNTAIN}

No brooder is complete without one of these simple sanitary fountains. Baby chicks can't get wet. Sets in corner of brooder. Takes up little room. Can't be upset. Can be hung up if desired. Absolutely sanitary, as you can get at any part of it to clean.

No. $0-1$-qt. capacity..... \$. 50

\section{Hudson Midget Sprayer}

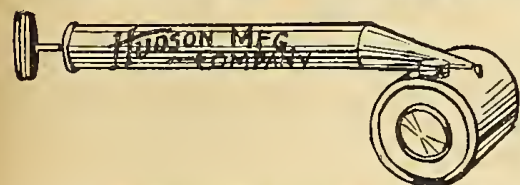

Hudson Midger Sprayer

\section{HUDSON NEW MISTY SPRAYER (NO. 4512)}

The best-selling quart-size sprayer. Made of good stock and carefilly testid. The nose of the pump passi's thru the ton of the can, keening the air nozzle and spray tube al ways in line and adding can, keening the air nozzle and spray. Eube ways wine line and adding great stringth to the whole sprayer. Every one carcfilly tested and
will give more service for the investment than any others of its type. Pumn 13/4" diameter, 14" long, pointed nose, selected plunger leather and hravy rod.

Tank $4^{\prime \prime}$ diametrr, $41 / 2^{\prime \prime}$ long. lock seamed. Capacity one full quart. Length over-all $21^{\prime \prime} ; 75 \mathrm{cts}$.
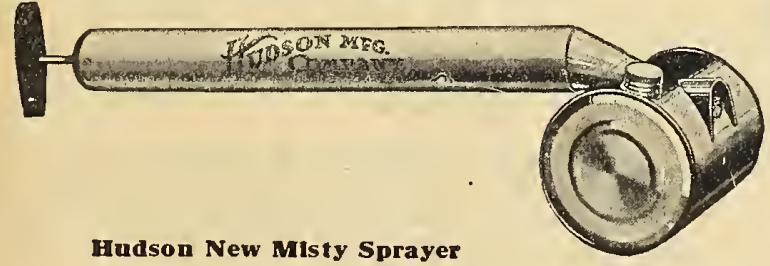

\section{MODEL THERMOMETERS}

The Nodel "Tri-Tested" Incubator Thermometers aro all seasoncd tubes tubes that are at least one year old.

? odel Incubators are only guaranteed by us when operated with the Niodel "Tri-Tested" Thermometers.

Prices

"Tri-Tested" Thermometer, postpaid ..... \$ .85

Two Thermometers. postpaid.

1. 60

\section{MODEL BROODER THERMOMETERS}

These Brooder Thermometers are designed to go through the top of the Brooder or Hover so that the temperature may be read rom the outside.

Chick Comfort Hover Thermoneters, postpaid ........... 85

\section{INCUBATOR AND BROODER LAMPS}

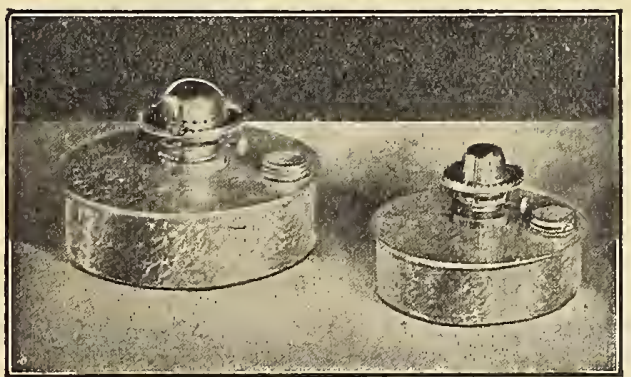

Prices of Incubator Lamps.

Small size, for Nos. $0,1, \mathbf{A}, \mathbf{B}$ and New Homestead Incubators $\$ 1.35$ Large size, for Nos. $2,3,4$ and $\mathrm{C}$ incubators............ 1.65 Prices ol Brooder Lamps.

For Portable Hover and all 1911 Brooders; Colony and Double Indoor Brooders, 1910 style, \$1.25: Chimney, 35c extra.

For Portable Hover and Model B Brooders, 1910 style A and B Brooders, 1912, \$1.25 each, Chimney 35c extra.

For Portable Hover and Chick Comfort Hover and Colony C, 1912 , $\$ 1.25$ each; Chimney, 35c extra.

Be sure to specify size and style of incubator and brooder for which lamps are wanted.

\section{RA B B I T SUPPLIES}

There has been a growing interest in the RABBIT INDUSTRY in our state for the past few years and the care and breeding of various BREEDS of RABBITS has reached proportions larger than can be realized. Recently an Association was organized for the promotion of this industry and officers were elected which should insure bettcr quality and more scientiflc methods, as plans are already made for a State Show which should bring the Breeders together and put this industry on a hore scientific methods, as plans are already made por a
FLORIDA BRE Association will be known as "THE to maintain health and give maximum results. We have been having a big demand for a balanced grain Rabbit Food and to meet this requirement we have prepared three mixtures approved by Rabbit Brceders which are composed of the choicest grain and seeds.

No. 1. UTILITY RABBIT FEED (for general use) containing Cracked Corn, Oats, Barley and wheat.

Meal Barley No. 3. FOR YOUNG RABBITS

young Prices on ferd as follows: No.1 not fed too liberally. A good substitute for green feed is Alfalfa eal.

Prices on feed as follows: No. 1 - L TILITY RABBIT FEED, $10 \mathrm{lbs}$., $60 \mathrm{c} ; 25 \mathrm{lbs} ., \$ 1.25 ; 50 \mathrm{lbs}$., $\$ 2.25 ; 100 \mathrm{lbs}$., $\$ 4.25$,

No. 2 -BREEDING DOES, 10 lbs., $75 \mathrm{c} ; 25$ lbs., $\$ 1.50 ; 50$ lbs., $\$ 2.50 ; 100$ lbs., $\$ 4.75$.
No. 3 -YOUNG RABBITS, 10 lbs.. $75 \mathrm{c} ; 25$ lbs., $\$ 1.50 ; 50$ lbs., $\$ 2.50 ; 100$ lbs., $\$ 4.75$.

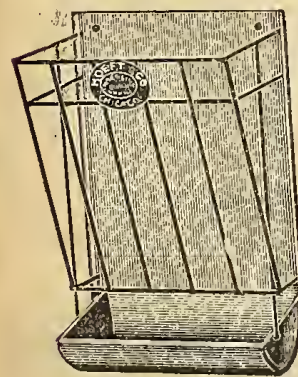

\section{MOE'S HAY AND FEED RACK}

For holding Roots or Hay, Alfalfa, Clover, etc. It prevents scattering Hay and wasting. The round trough at the bottom catches the small tender leaves. Feed saved soon pays for Rack. No. 44-Packed 6 in. Weight 10

lbs. Price, each..........\$.75

\section{MOE'S FEED AND WATER DISH}

Made of Galvanized Iron. Rolled in top prevents wasting. Dish held to the floor of Hutch by simple locking device easy to remove for cleaning. Impossible for stock to tip over. No. $46 \rightarrow$ Packed 12 in. Weight 7 lbs. Price, each.

\section{Moe's Feed and Water Cup}

Made of Galvanized Iron. For hanging on th side of Futch or Exhibition cage. A favorite with many breeders.

No. 61-Packed 48 in. Weight, 24 lbs.

Price, each.
$\$ .25$

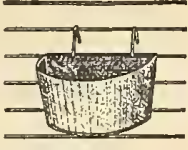




\section{KEEN KUTTER}

Easy Working Garden Tools-Are Guaranteed to Give Their Users Entire Satisfaction

\section{KEEN KUTTER HEDGE SHEARS}

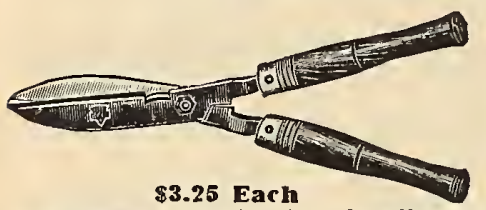

Blade and Shank hand forged from one piece of highest grade crucible steel; faces of blades polished; backs of blades and tangs natural finish; blades notched for cutting large sticks; heavy steel hinge bolt offset tangs extending into handles and riveted through; varnished offset tangs extending into handles and rivet

hard wood handles with copper plated ferrules.
No. KH8 - Blades are 8 inches long, handles 1012 inches long.

\section{KEEN KUTTER PRUNING SHEARS}

Extra finish, heavy malleable iron frame, with closed bow grip. end catch and carefully ground hooks; and carefuly ground hooks: nickle-plated steel nesting coil spring: highest grade coil spring; highest grade crucible steel heavy blade,
riveted on, extra ground

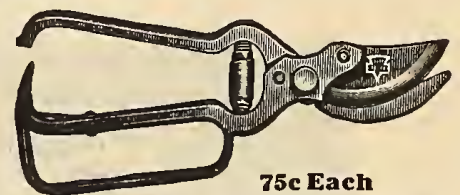
and sharpened; length over all 9 iucuss, vlade 3 inches long; bow 4 inches long. and hook.

\section{KEEN KUTTER DIRT SHOVELS}

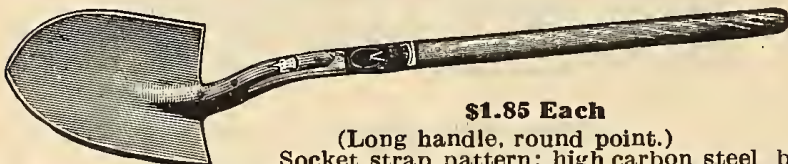

Socket strap pattern; hirh carbon steel blade and straps: blade extra tempered and edges sharpened; fitted with extra select ash handles.

No. KLR2-Polished blade 12 inches long, 9 3-4 inches wide; handle $\overline{5} 1$ inches long.

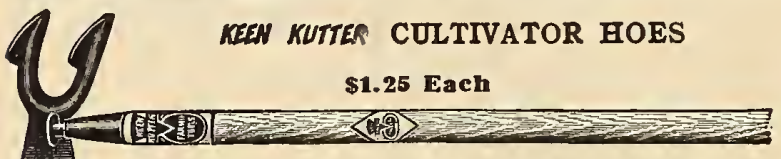

Special crucible forged steel polished blade and painted points; select second growth straight-grained ash handle;
smooth belted, black lacquered steel ferrule; gold No. KA-Corrugated points 3 inches long, 4 3-4 inches spread: malleable iron riveted shank; flaring blade, 5 inch cut; length of head. 10 inches; length of handle, $41 / 2$ feet.

\section{KEEN KUTTEA D-HANDLE SPADES}

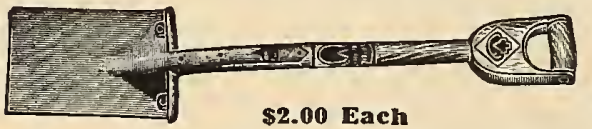

Socket $\mathrm{s}$ t $\mathrm{r}$ a $\mathrm{p}$ pattern; m a d with high carbon steel blade and straps. The blade and edge sharp-

ened, handle of extra select ash.

No. KSD2-Square point polished, blade 12 inches long, $71 / 2$ inches wide; handle 27 inches long.

\section{SCREENING SCOOPS \$2.50 Each}

FOR POTATOES, EAR CORN, ONIONS, ETC.

Wood D-handle; 8 gauge steel wire screening blade, with 1/4-in. round steel wire side braces: 14 gauge steel straps: 10 gauge steel front edge.

No. WS-Blue Lacquered finish; length of scoop, 17 inches; width of scoop, $14 \frac{1}{2}$ inches; length of handle, 27 inches.

\section{BAY STATE GARDEN TROWELS}

Excellent to o l for ransplanting flowers. Nialleable iron shank, riveted to blade.

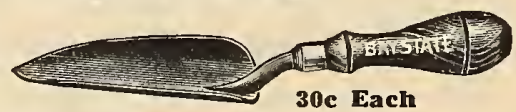

No. B6-Length of 30e Each

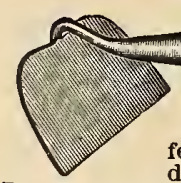

KEEN KUTTER GARDEN HOES depth of blade, $43-4$ in.: pitch or set of blades, $74 \frac{1}{2^{\circ}}$; cutting blades assorted, $61 / 2$ to $7 \frac{1}{2}$ inches wide.

\section{OAK LEAF POTATO HOOKS}

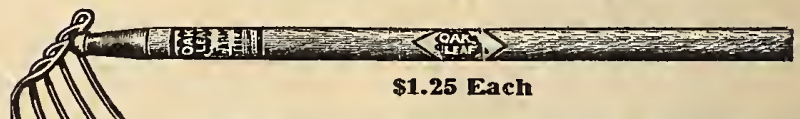

Special crucible forged steel tumbled flnish prongs tempered and tested; bent head, gold bronzed; select smooth belted and labeled straight ash handle; gold bronze steel ferrule and cap; shank not riveted.

No.E5R-Five round prongs, 7 inches long; total width, $61 / 2$ inches; handle $41 / 2 \mathrm{ft}$. long.

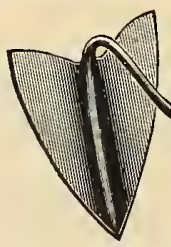

\section{MATTOCK HOES}

\section{\$1.00 Each}

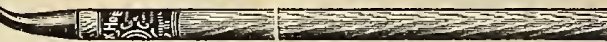

Special crucible forged steel polished blade and points: select smooth belted straight ash handle; topered, ridged and eared blade; gold bronzed steel neck and socket. $1 / 2$ - Warren pattern; length of blade, $71 / 2$ inches; width of blade, 6 3-8 inches; length of handle, $4 \mathrm{~b} / 2$ feet.

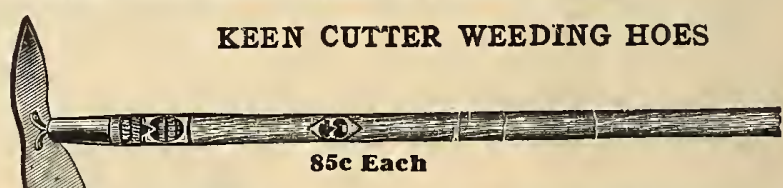

Highest grade crucible steel; tempered and polished blade and prong, sharpened; extra select second growth straight grained ash handle, polished and waxed; onestraight grained ash hande, polshed and werrule. piece steel double shank; black lacquered steel plain feet; width of cut, 4 inches; length of blade, 9 inches.

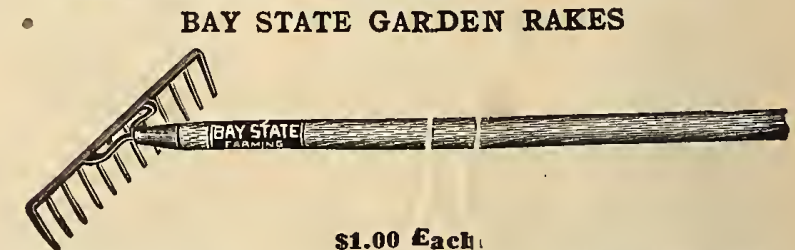

Malleable iron head and braced sha nk, straight teeth, japanned finish; steel ferrule: $6 \mathrm{ft}$. straight hard wood handle.

No. BMB10-With 10 teeth; 10-in 1. head.

No. BMB12-With 12 teeth: 12-inc. head.

No. BMB14-With 14 teeth: 14-irc head.

GRASS HOO KS

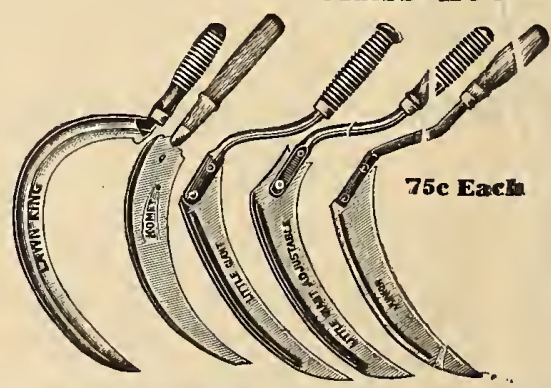

No. 100 -Made with crucible forged steel, 11 and 12-in. cutting blade hollow ground, tempered and sharpened to razor edge. Assorted pattern blades and handles. 


\section{MARTIN'S PLANTS}

\section{Grown on Our Own Farm}

Two years ago we decided to grow our own plants and since that time we have been furnishing our customers with Fresh-dug plants direct from our own plant farm. Our plant business is increasing rapidly as our customers appreciate the quality of our plants and now our plants are enjoying the same good reputation as Martin's $H \mathbf{y}$-Test Seeds always have.

We are striving to give our customers the best of everything and we know that if you haven't been buying everything and we know that if you haven t been buying fall that they will please.

We expect to be able to supply all seasonable plants and we are listing below a few varieties. If you are in need of plants, write us for special price list and information as it is not practical to name prices at this time.

PLANT MARTIN'S FRESH-DUG PLANTS FOR BEST RESULTS.

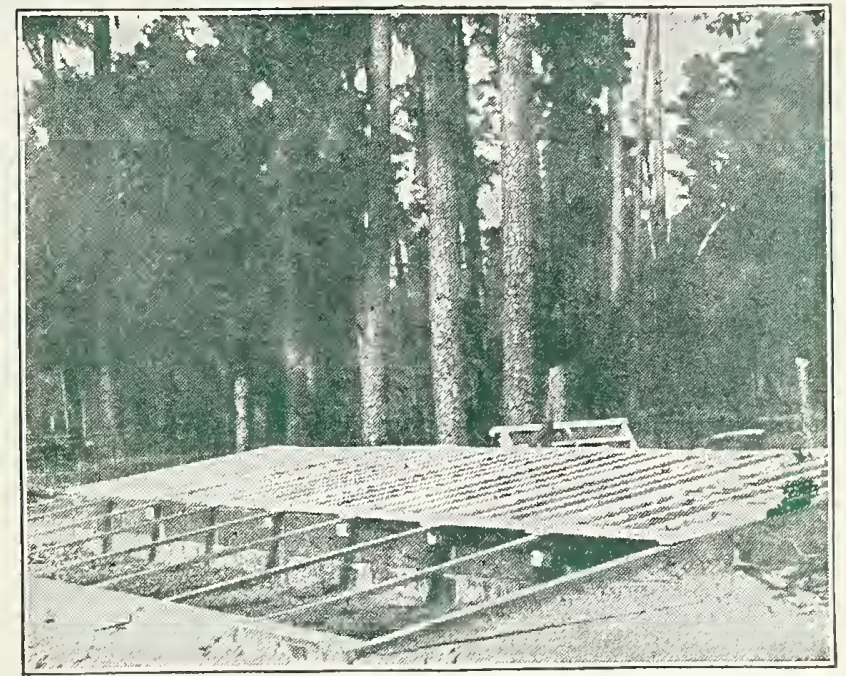

One of the many bot-beds on our own farm where we grow our plants

\section{CABBAGE PLANTS BX PARCEL, POST, PREPATD (Frost Proof)}

Grown from best seed and not imported seed; shipped direct from our growing stations-shipment from October to April 15th. Transplant deep, up to the first leaf, in deep, rlch soil, and water nlants well. Set out two to three feet in row: rows thirty inches apart, 7,000 to 8,000 plants per in row; rows tor use in 100 to 150 days. Varieties: Jersey acre, ready for use in 100 to 150 day's. Varieties: Jersey Dutch. Terms, cash with order. No plants shipped O. O. D.

\section{LETTUCE PLANTS}

Ready for shipment from November 1st until May. Prlces on application.

\section{CAULIFLOWER PLANTS}

Ready for shipment October 15th.

Early Snowball.

\section{EGGPLANTS AND PEPPER}

Plants in season. The most popular varieties.

$$
\text { ONION PLANTS }
$$

Crystal Wax and White Bermuda. Ready for shipment from November to A pril. Prices on application.

\section{TOMATO PLANTS}

We can furnish from February until June.

Earllana, Globe, Beauty Ponderosa.

Prices on application.

\section{COLLARD PLANTS}

Ready for shipment October 15 th

Fine Georgla Collards and $N$. C. Short Stem.

\section{FLOWER PLANTS}

Wo can furnish Shasta Dalsy Plants, Pansy Plants. Cosmos, Salvla or Scarlet Sage.

Get our price list in season.

\section{SHASTA DAISY}

A fine perennial plant bearing large white single blogsoms with yellow centers. Soak seed in warm water over night bofore nowing.

Note strong root growth of oxr Strawberry Plants.

\section{STRAWBERRY PLANTS FOR FLORIDA}

Can be set out in July and August during the raing eason to procure best results for early berries in December. One of the essential conditions for growing strawberries in Florida is the selectlon of a well-drained field, preferably pine land with a clay subsoil. The first step is to plow land thoroughly, then broadcast commercial fertilizer about one ton to acre. Harrow in thoroughly, and after this is done lay off the beds five feet wide with an eight-ineh shovel running twice to the furrow; then pull the dirt from middle of furrow to center of bed. Iay off rows twelve inches apart. four rows to the bed. Set plants fifteen inches apart in the rows. After plants are set, work around plants one week after setting. Cultivate at intervals of two weeks during July, August and September to October give second application of vegetable fertilizer at rate of of vegetable fertinzer at rate of Whe thousand pounds to acre. When bushes begin to show the bloom forms, apply five hundred A slight mulch of pine tops or straw applied after cultivation will improve the quality and cleanliness of the fruit.

Klondyke. - The true Klondyke Strawberry we offer, proven to be one of the most valuable Southern berries. When fully ripe it is of excellent table quallty, having a decided flavor, aroma and character of its own. Grows on a long stem. This keeps the berry clear of the ground, causing them to require less mulching than most kinds. This is also a safoguard against frost. It is a plant of remarkably vigorous growt

Misslonary.-A new variety, very popular through the trucking districts. Strong grower, making plants freely; early to mature, coming in directly after Excelsior, and very productive. The berries are well colored, firm, large, and hold their size well throughout the season Good shipping qualities, and is being planted on an extensive seale by berry growers.

We only offe- two varletles. although the number of vaalthough the number of varletles are many. These two

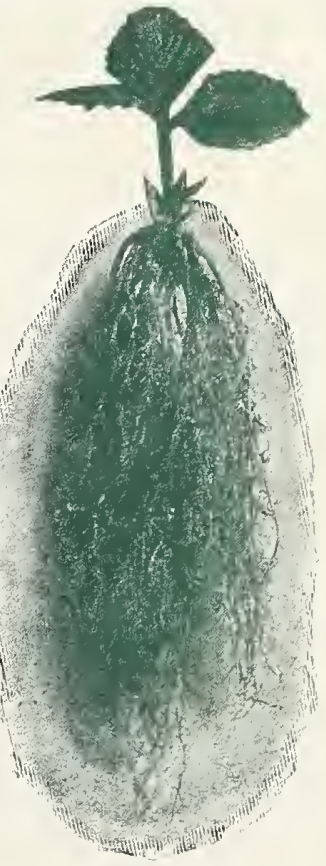




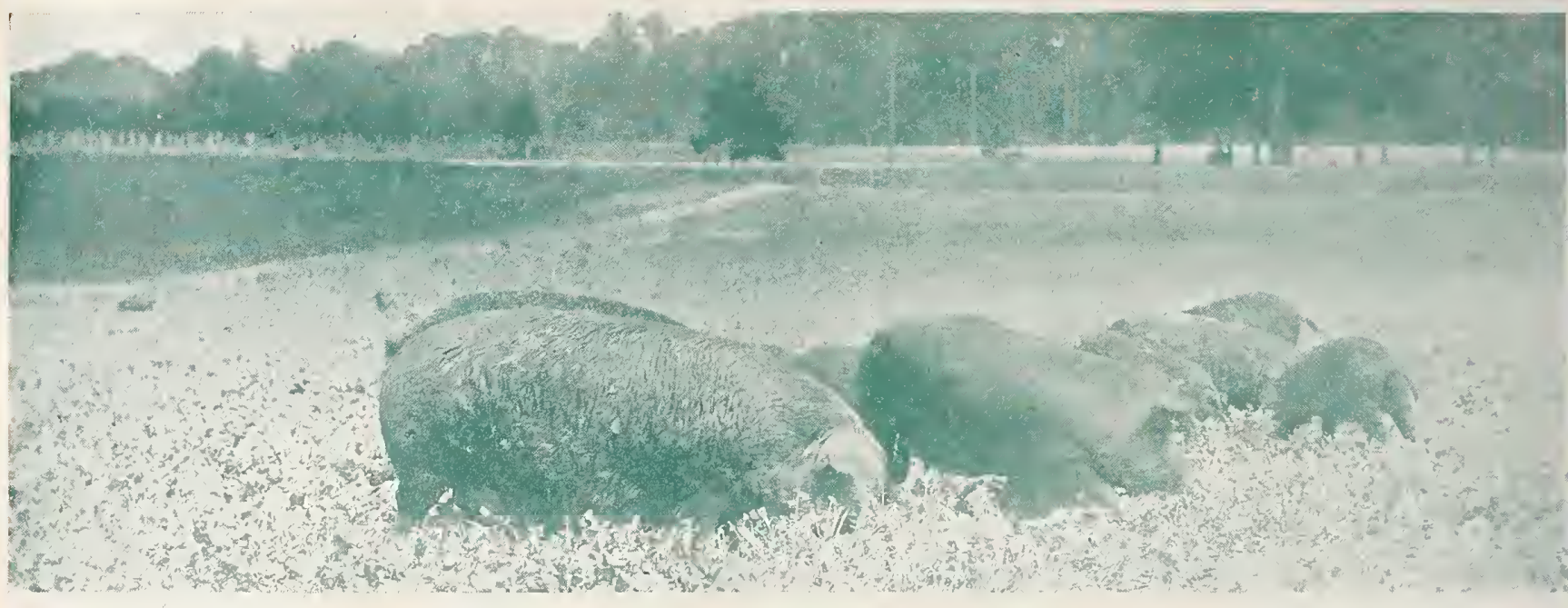

Pure-Bred Duroes grazing in field of By-Test Rape at "Roseland Farm" All live stock on our farm are pure-breds
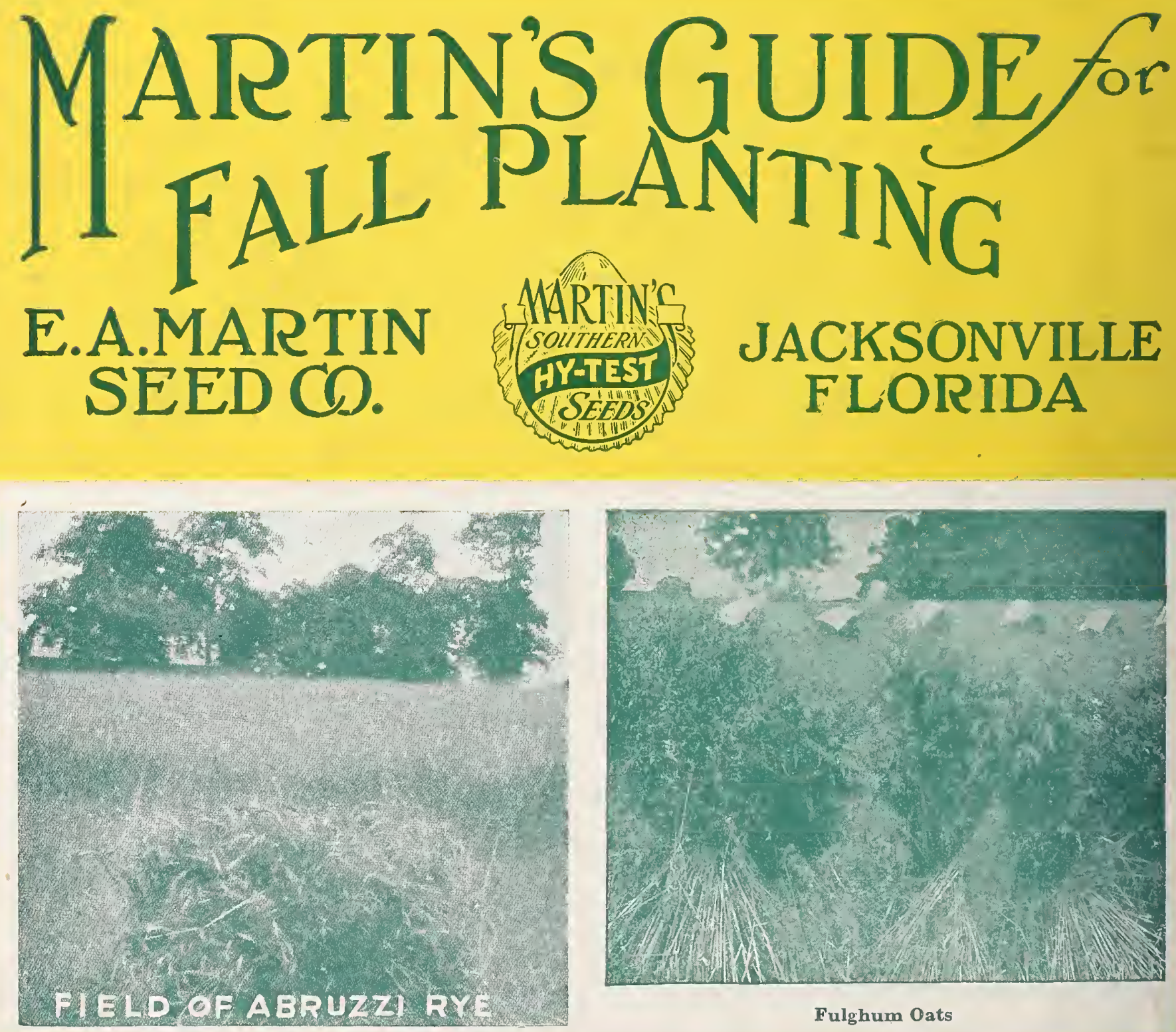